\title{
Aplicação de práticas ágeis na construção de data warehouse evolutivo
}

\author{
Guilherme Tozo de Carvalho
}

\author{
DisSERTAÇÃO APRESENTADA \\ $\mathrm{AO}$ \\ Instituto de Matemática e Estatística \\ DA \\ Universidade DE SÃo PAUlo \\ PARA \\ ObTenÇÃo Do Título \\ $\mathrm{DE}$ \\ MestRe
}

Programa: Ciência da Computação

Orientador: Prof. Dr. João Eduardo Ferreira

1 de junho de 2009 


\section{Aplicação de práticas ágeis na construção de data warehouse evolutivo}

Este exemplar corresponde à redação final da dissertação devidamente corrigida e defendida por Guilherme Tozo de Carvalho e aprovada pela Comissão Julgadora. 


\section{Resumo}

Um data warehouse (DW) é um banco de dados centralizado, orientado por assunto, integrado, não volátil e histórico, criado com o objetivo de dar apoio ao processo de tomada de decisão e que estrutura os dados em uma arquitetura analítica bastante distinta da arquitetura relacional utilizada nos bancos de dados transacionais. Construir um DW é um projeto de engenharia bastante complexo pois envolve muitas tecnologias e muitas pessoas, de diferentes equipes, em um grande esforço conjunto para construir esta base central de informações corporativas. O processo tradicional de construção de um DW não utiliza conceitos ágeis e, pelo escopo de desenvolvimento ser grande, pode levar muito tempo até que funcionalidades sejam entregues aos clientes.

Os métodos ágeis de engenharia de software são muito usados como uma alternativa aos métodos tradicionais de desenvolvimento e têm diferenciais que trazem muito valor a projetos grandes pois, além de buscar desenvolver versões funcionais em prazos curtos, defendem que todos os sistemas têm a constante necessidade de se adaptar a mudanças. Estas duas características, presentes em todos os métodos ágeis, trazem alguns benefícios estruturais aos projetos em que são aplicados pois, além da constante priorização das necessidades mais recentes, também permitem que novas funcionalidades sejam constantemente adicionadas, fazendo com que o sistema esteja sempre adaptado às maiores necessidades da empresa.

Neste trabalho são aplicadas práticas ágeis no processo tradicional de engenharia de DW para que o desenvolvimento seja realizado em ciclos iterativos curtos, tornando possível o desenvolvimento rápido e evolutivo de um DW com entregas constantes de novas funcionalidades. A contínua evolução deste complexo ambiente analítico é apoiada por conceitos de banco de dados evolutivos e também por fundamentos de métodos ágeis.

Palavras-chave: Data Warehouse, Métodos Ágeis, Refatoração, Banco de Dados. 


\section{Abstract}

A data warehouse (DW) is a central database, subject-oriented, integrated, nonvolatile, and timevariant collection of data in support of management's decision making process and that summarize the data in an analytic architecture quite different from the relational one, used in transactional databases. Building a DW is a complex engineering project because it involves many technologies and many people, from different teams, in a huge corporative effort to build a central database with corporative data. The traditional engineering process to build a DW does not use agile concepts and, as its scope is quite big, it might takes a long time until the customer can use its features.

Agile methods of software engineering are commonly used as an alternative to the traditional methods and they have some differentials that lead a lot of value to big projects, as the continuous attempt to develop short releases in short periods of time, or the belief that every system needs to be continuously adapted to the changes on its environment. These two features, which appear in all the agile methods, brings some structural benefits to the projects where they are applied as the continuous priorization of the most recent company needs, they also allow new functionalities to be constantly added in the system, directing it continuously to the highest priority needs of the company.

This work applies agile practices in the traditional DW engineering method, so that the development can be done in short iterative cycles, making possible a fast and evolutive DW project, with frequent delivering of new functionalities. The continuous evolution of this complex analytical environment is supported by evolutive database concepts and also for agile methods foundations.

Keywords: Data Warehouse, Agile Methods, Refactoring, Database. 


\section{Agradecimentos}

À minha esposa Cristiane Rodrigues Guzzo Carvalho, sempre presente, dedicada, compreensiva e carinhosa. Eu te amo muito Cris.

À minha família, Sebastião de Almeida Carvalho, Maria Madalena Tozo de Carvalho, Rafael Tozo de Carvalho e Victor Tozo de Carvalho, por todo o apoio e incentivo que me deram ao longo deste difícil trabalho.

Ao meu orientador Prof. Dr. João Eduardo Ferreira, pela sua importante orientação e pelas idéias, fundamentais no direcionamento e na execução do trabalho.

À minha co-orientadora Profa. Dra. Isabel Cristina Italiano, pela paciência que teve, pela ajuda nas idéias e no texto da dissertação e por ter sempre acreditado em mim.

Aos meus companheiros da empresa, pela flexibilidade que tive em meus horários, pela compreensão e pelo apoio que me deram para que o trabalho fosse realizado. Atualmente na Cetelem: Luiz Maurício Germano Simões, Franck Vignard-Rosez, Camila de Campos, Camila Poplawski, Flávio Itiro, Raquel Furuya, Marcos Chiba e Diogo Goes. No início do curso, na Telefonica e na VIVO: Welkens Reis Dutra, Gilson Vilela, Filipe Moura, Fernando Nagano e Maribel Garcimartin.

Aos meus sogros Henrique Guzzo Júnior e Dionilde Rodrigues dos Santos Guzzo, pelo apoio, pelo incentivo e pela compreensão que tiveram durante o trabalho.

A todos os meus amigos e familiares que me apoiaram e me incentivaram nos momentos difíceis, me dando forças e acreditando em mim.

Muito Obrigado! 


\section{Sumário}

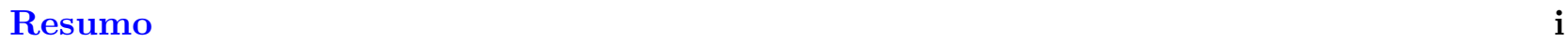

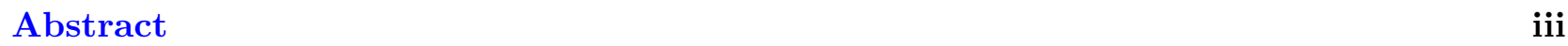

$\begin{array}{lc}\text { Lista de Abreviaturas } & \text { xi }\end{array}$

Lista de Figuras $\quad$ xiii

Lista de Tabelas $\quad$ Xv

1 Introdução $\quad 1$

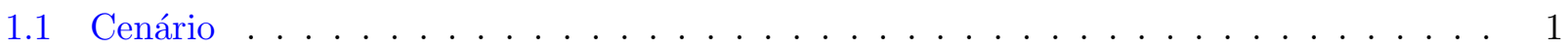

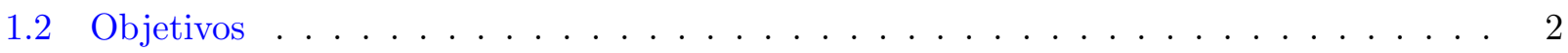

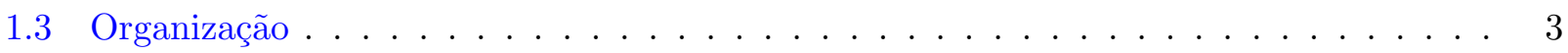

2 Processo Tradicional de Construção do DW $\quad 5$

2.1 Planejamento do Projeto . . . . . . . . . . . . . . . . . . . . 6

2.2 Especificação de Requisitos de Negócio . . . . . . . . . . . . . . . . . . . . 9

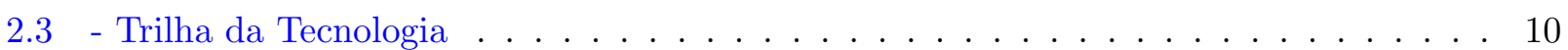

2.3.1 Projeto da Arquitetura Técnica . . . . . . . . . . . . . . . . . . . 10

2.3.2 Escolha e Configuração de Ferramentas . . . . . . . . . . . . . . . . . . . 12

2.4 - Trilha dos Dados . . . . . . . . . . . . . . . . . . . . 12

2.4 .1 Modelagem Dimensional . . . . . . . . . . . . . . . . . . . . . . 13 


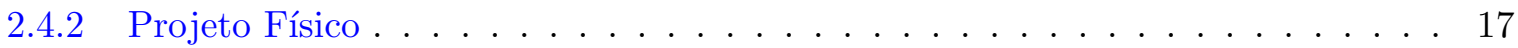

2.4 .3 Projeto do ETL e Desenvolvimento . . . . . . . . . . . . . . . . . 19

2.5 - Trilha das Aplicações de BI . . . . . . . . . . . . . . . . . . . 26

2.5 .1 Projeto de Aplicações de BI . . . . . . . . . . . . . . . . . . 27

2.5.2 Desenvolvimento da Aplicação de BI . . . . . . . . . . . . . . . . . 28

2.6 Integração e Implantação ～. . . . . . . . . . . . . . . . . . . . . . . . . . 29

2.7 Manutenção . . . . . . . . . . . . . . . . . . . . . . . . 30

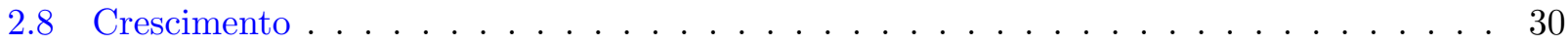

2.9 Gerenciamento do Projeto . . . . . . . . . . . . . . . . . . 31

2.10 Resumo do Capítulo . . . . . . . . . . . . . . . . . . . . 32

3 Métodos de Evolução em Bancos de Dados $\quad 33$

3.1 O Conceito de Bancos Evolutivos . . . . . . . . . . . . . . . . . . . 33

3.2 Refatoração de Banco de Dados . . . . . . . . . . . . . . . . . . . . . . 35

3.3 Aplicando as Refatorações . . . . . . . . . . . . . . . . . . . . . . 37

3.4 Implantando em Produção . . . . . . . . . . . . . . . . . . . . . . . . . . . . 39

3.5 Classificação das Evoluções de um DW . . . . . . . . . . . . . . . . . . . . . . 41

3.6 Resumo do Capítulo . . . . . . . . . . . . . . . . . . . . . . . . . . . 42

4 Aplicação de Práticas Ágeis em Projetos Evolutivos de DW 43

4.1 Métodos Ágeis . . . . . . . . . . . . . . . . . . . . . . . . 43

4.2 As Duas Práticas Principais . . . . . . . . . . . . . . . . . . . . . 45

4.3 Técnicas para Aplicação das Práticas Ágeis . . . . . . . . . . . . . . . . . . . . 48

4.4 Aplicação das Práticas Ágeis - Um exemplo ilustrativo . . . . . . . . . . . . . . . . 51

4.5 A Estabilidade Estrutural . . . . . . . . . . . . . . . . . . . . . 53

4.6 Enumeração das Evoluções . . . . . . . . . . . . . . . . . . . . . . 54

4.7 Resumo do Capítulo . . . . . . . . . . . . . . . . . . . . . 58 
5 Exemplo de Aplicação $\quad 59$

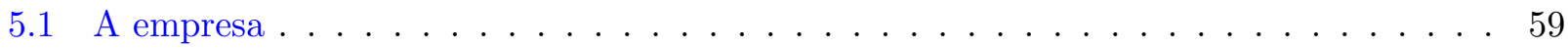

5.2 A 1a iteração . . . . . . . . . . . . . . . . . . . . . 59

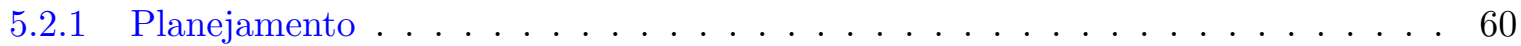

5.2 .2 Especificação de requisitos . . . . . . . . . . . . . . . . . . 60

5.2 .3 Trilha da tecnologia . . . . . . . . . . . . . . . . 62

5.2 .4 Trilha dos dados . . . . . . . . . . . . . . . . . . 63

5.2 .5 Trilha das aplicações de BI . . . . . . . . . . . . . . . . 69

5.2 .6 Integração e implantação . . . . . . . . . . . . . . . . . . . . 70

5.2 .7 Manutenção . . . . . . . . . . . . . . . . . . . . . . . 71

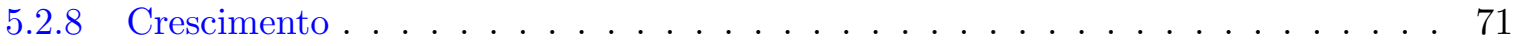

5.2 .9 Gerenciamento . . . . . . . . . . . . . . . . . 72

5.3 A 2 a iteração . . . . . . . . . . . . . . . . . . . . . . . . 72

$5.3 .1 \quad$ Planejamento . . . . . . . . . . . . . . . . . . 72

5.3 .2 Especificação de requisitos . . . . . . . . . . . . . . 73

5.3 .3 Trilha da tecnologia . . . . . . . . . . . . . . . 73

5.3 .4 Trilha dos dados . . . . . . . . . . . . . . . . . . 73

5.3.5 Trilha das aplicações de BI . . . . . . . . . . . . . . . . 75

5.3 .6 Integração e implantação . . . . . . . . . . . . . . . . . . . 75

5.3 .7 Manutenção . . . . . . . . . . . . . . . . . . . . 76

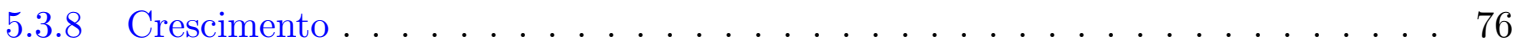

5.3 .9 Gerenciamento . . . . . . . . . . . . . . . . 77

5.4 A 3 a iteração . . . . . . . . . . . . . . . . . . . . . . . 77

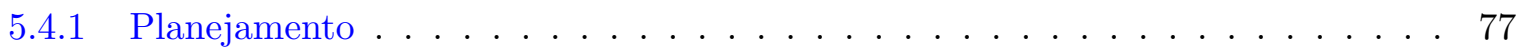

5.4 .2 Especificação de requisitos . . . . . . . . . . . . . . . . 77 
5.4 .3 Trilha da tecnologia . . . . . . . . . . . . . . . . 77

5.4 .4 Trilha dos dados . . . . . . . . . . . . . . . . . 78

5.4 .5 Trilha das aplicações de BI . . . . . . . . . . . . . . . . . 80

5.4 .6 Integração e implantação . . . . . . . . . . . . . . . . . . . . 80

5.4 .7 Manutenção . . . . . . . . . . . . . . . . . . . . . 81

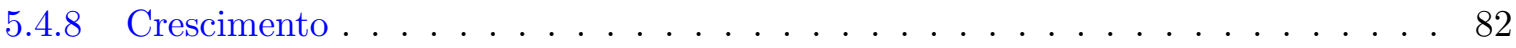

5.4 .9 Gerenciamento . . . . . . . . . . . . . . . . . . 82

5.5 Resumo do Capítulo . . . . . . . . . . . . . . . . . . . . . 82

6 Conclusão $\quad 85$

6.1 Contribuições do trabalho . . . . . . . . . . . . . . . . . . . 86

6.2 Pesquisas Futuras . . . . . . . . . . . . . . . . . . . 87

A Apêndice: Alguns exemplos de evoluções de BD $\quad 89$

$\begin{array}{ll}\text { Referências Bibliográficas } & 95\end{array}$ 


\title{
Lista de Abreviaturas
}

\author{
ASD Adaptive Software Development. \\ BSC Balanced Scored Card. \\ BI Inteligência de Negócio (Business Intelligence). \\ DM Data Mart. \\ DW Data Warehouse. \\ ETL Extração, Transformação e Carga (Extraction, Transformation and Load). \\ OLAP On-Line Analytical Processing. \\ RFV Recência, Freqüência e Valor. \\ SCD Dimensões que Mudam Lentamente (Slowly Changing Dimensions). \\ SGBD Sistema Gerenciador de Banco de Dados. \\ SQL Structured Query Language. \\ XP Programação Extrema (Extreme Programming).
}




\section{Lista de Figuras}

2.1 Processo de engenharia de DW segundo Kimball $[38] \ldots \ldots$. . . . . . . . . . 6

2.2 Exemplo de modelo dimensional: Esquema Estrela . . . . . . . . . . . . . . . 13

2.3 Projeto físico da base . . . . . . . . . . . . . . . . . 18

2.4 Fluxo do processamento ETL para manutenção de dimensões . . . . . . . . . . . . . 21

2.5 Atribuição de chaves numéricas (surrogate keys) no lugar das chaves do ambiente transacional, utilizando tabelas de lookups . . . . . . . . . . . . 23

3.1 Exemplos de níveis de acoplamento baixo em (A) e alto em (B) . . . . . . . . . 34

3.2 Diagrama do processo de Refatoração de Banco [54] . . . . . . . . . . . . . . . . 37

3.3 Implantação em produção após realizar refatoração no banco . . . . . . . . . . . . . 40

4.1 Pontos do processo de engenharia mais afetados pela aplicação das práticas ágeis . . 47

4.2 Exemplo de três ciclos de desenvolvimento curtos, ou "semanais" . . . . . . . . . . 51

4.3 Exemplo de consulta, que mostra a estabilidade do modelo dimensional diante a evoluções comuns na construção de um DW evolutivo . . . . . . . . . . . . . 54

5.1 Modelo lógico da 1 a iteração . . . . . . . . . . . . . . . . 65

5.2 Modelo físico da 1a iteração . . . . . . . . . . . . . . . . . 65

5.3 Mapeamento de fontes para a tabela de fatos . . . . . . . . . . . . . 66

$5.4 J o b$ que realiza a agregação dos dados transacionais . . . . . . . . . . . . . 68

5.5 Sequenciador dos jobs da tabela de fatos . . . . . . . . . . . . . . . . 69

5.6 Exemplo de dois relatórios implementados nesta iteração . . . . . . . . . . . . . . 71 
5.7 Modelo lógico da 2 a iteração . . . . . . . . . . . . . . . . . . . . 73

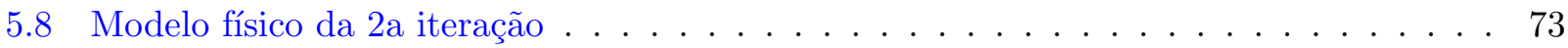

5.9 SCD para a dimensão de produtos . . . . . . . . . . . . . . . . . . . . . 74

5.10 SCD para a dimensão de produtos . . . . . . . . . . . . . . . . . 75

5.11 Dois novos relatórios implementados na segunda iteração . . . . . . . . . . . . . . . 76

5.12 Modelo lógico da 3a iteração . . . . . . . . . . . . . . . . . . . . . . 78

5.13 Modelo físico da 3a iteração . . . . . . . . . . . . . . . . . . . . . . . . 79

5.14 Processo de atribuição de chaves antes da carga na tabela de fatos . . . . . . . . . 80

5.15 Distribuição dos cartões por status de segmento . . . . . . . . . . . . . 81 


\section{Lista de Tabelas}

2.1 Atividades na fase inicial do projeto . . . . . . . . . . . . . . 7

3.1 Categorias de refatorações de banco . . . . . . . . . . . . . . . . 36

3.2 Categorias de refatorações de banco de dados . . . . . . . . . . . . . . . . . 42

4.1 As duas principais práticas ágeis para desenvolvimento evolutivo de DW . . . . . . . 46

4.2 Outras práticas com características adequadas para aplicação em projetos evolutivos de DW . . . . . . . . . . . . . . . . . . . . . . 47

5.1 Estrutura da especificação de requisitos . . . . . . . . . . . . . . . . . . 61

5.2 Requisitos de hardwares para o projeto . . . . . . . . . . . . . . . . . 62

5.3 Requisitos de softwares para o projeto . . . . . . . . . . . . . . 63 


\section{Capítulo 1}

\section{Introdução}

\subsection{Cenário}

Em um mercado onde empresas de todo o mundo disputam clientes como se não houvessem barreiras geográficas, inovar é um conceito fundamental para qualquer corporação e uma prática muito necessária à conquista de diferenciais competitivos. Nesse ambiente, está um conceito conhecido há muito tempo, que é a inteligência de negócio (ou BI - Business Intelıigence) [10,22]. Tratase de um conjunto de processos que permitem, a partir dos dados da empresa, adquirir e apresentar informações úteis, orientadas a negócios e a resultados, que auxiliam na tomada de decisões [10]. Para que este processo seja automatizado e tenha todo o apoio computacional possível, uma complexa infra-estrutura tecnológica é necessária, cujo principal componente é o data warehouse ${ }^{1}$.

Um data warehouse (DW) é um banco de dados centralizado, orientado por assunto, integrado, não volátil e histórico, criado com o objetivo de dar apoio ao processo de tomada de decisão e que estrutura os dados em uma arquitetura analítica bastante distinta da arquitetura relacional utilizada nos bancos de dados transacionais [27]. Utilizar um DW como fonte para as ferramentas de BI é uma boa estratégia, pois este banco tem uma estrutura eficiente no armazenamento de grandes volumes de dados, oferece uma visão única do negócio e é fisicamente separado do ambiente transacional, evitando prejuízo no desempenho dos servidores transacionais. Além disso, o DW tem características estruturais que buscam maximizar o desempenho analítico e utiliza um modelo de dados dimensional, adequado a este fim [35].

Apesar de ser uma solução poderosa, trata-se de um projeto muito grande, que envolve muitas pessoas, diversas áreas da empresa, diferentes tecnologias e, por isso, muitos projetos de DW tardam a apresentar resultados efetivos ou sequer são finalizados. Segundo estudo de 2005 do grupo Gartner [21], cerca de $50 \%$ dos projetos de DW estavam tendendo ao fracasso por erros como o tempo de desenvolvimento, que causa demora na entrega das funcionalidades aos usuários finais. Quando

\footnotetext{
${ }^{1} \mathrm{O}$ termo data warehouse, ou DW, é utilizado em inglês pois sua tradução para o português, que é "Repositório de Dados" praticamente não é utilizada em trabalhos científicos e o termo em inglês é padrão em trabalhos sobre o assunto.
} 
o sistema é finalmente disponibilizado, é comum que diversas funcionalidades desenvolvidas já estejam obsoletas, enquanto necessidades mais recentes tenham sido deixadas para fases futuras de desenvolvimento.

Mesmo quando estes projetos grandes e demorados são considerados bem sucedidos, a taxa de utilização das funções implementadas é baixa, com menos de $40 \%$ de suas funções em uso, segundo Johnson [30]. Isso ocorre devido à falta de sincronia entre a equipe de desenvolvimento e a de negócios, pois o tempo de desenvolvimento em um projeto grande prejudica o alinhamento entre o que usuário precisa e o produto implementado. Além disso, o processo tradicional de construção de DW, mesmo utilizando ciclos iterativos, não tem o compromisso de fazer entregas rápidas de funcionalidades, o que pode ser observado pela baixa preocupação com o tamanho de cada iteração, que pode ter um escopo grande o suficiente para que ocorram muitos dos problemas de um grande projeto de software.

Os métodos ágeis são muito aplicados como uma alternativa aos métodos tradicionais de desenvolvimento de software. O objetivo de ambos é produzir sistemas de alta qualidade que atendam às necessidades dos usuários e, o que os diferencia, são seus princípios para atingir estas metas [47]. Os

métodos ágeis têm uma abordagem que valoriza o respeito às pessoas, a contínua colaboração com o cliente e o aumento da produtividade [8], reduzindo o tempo gasto com atividades que não agregam valor ao projeto e fazendo com que as funcionalidades mais importantes do software sejam desenvolvidas e disponibilizadas para os usuários rapidamente. Os métodos ágeis têm sólida sustentação em conceitos de engenharia de software, com pouca ênfase burocrática e ignorando a idéia de que a especificação inicial deva atender um sistema completo, defendendo um desenvolvimento em ciclos curtos, com qualidade e de maneira organizada.

\subsection{Objetivos}

O principal objetivo deste trabalho é utilizar práticas ágeis no processo de engenharia de DW para superar a limitação do método tradicional, tornando possível o desenvolvimento rápido e evolutivo de um DW, com entregas constantes de novas funcionalidades. Para atingir este objetivo, é preciso aplicar duas práticas ágeis que, juntas, têm os fundamentos teóricos necessários para o desenvolvimento do DW evolutivo. Estas práticas são:

- Ciclo Iterativo: realizar ciclos curtos de desenvolvimento, garantindo a contínua entrega de funcionalidades. Os usuários passam a ver resultados rapidamente e não precisam esperar o término do DW completo para ter acesso a benefícios parciais.

- Projeto Incremental: permite que o projeto seja desenhado de forma incremental, em todas as suas etapas de construção. Esta prática é mais difícil de ser aplicada em evoluções no esquema de dados pois, com o banco populado, os dados precisam ser tratados de forma especial. Os conceitos de banco de dados evolutivos [54] oferecem forte apoio na aplicação desta prática. 
A implementação desses dois conceitos facilita a aplicação de outras práticas ágeis na construção do DW e todas elas passam a contribuir para que seja atingido o objetivo. Um exemplo é a implantação incremental, que é conseqüência direta da aplicação das duas práticas principais, ou ainda a execução de testes, uma forte necessidade em um projeto que faz implantações incrementais. No Capítulo 4 a implementação dessas práticas será discutida e serão descritas técnicas auxiliares, por exemplo, para identificar as funcionalidades prioritárias a serem desenvolvidas na iteração.

As práticas mencionadas no parágrafo anterior integram a maioria dos métodos ágeis, como por exemplo o Scrum [48,49] e a Programação Extrema [4,6,7] mas, apesar de compartilharem dos mesmos conceitos, têm nomenclaturas próprias em cada um dos métodos. Os principais métodos ágeis são descritos no capítulo 4, mas o objetivo do trabalho não é detalhar nenhuma metodologia específica, já que um processo de DW, ao contrário de projetos de software convencionais, tem poucas etapas relacionadas a atividades de programação.

\subsection{Organização}

Esta dissertação está organizada da seguinte forma: no Capítulo 2 é apresentado o processo tradicional de construção de um DW, o Capítulo 3 discute conceitos de bancos de dados evolutivos, com ênfase no assunto DW. No Capítulo 4 são apresentadas as diretrizes para implementação de práticas ágeis em projetos evolutivos de DW e o Capítulo 5 traz um exemplo de aplicação. Por fim, o trabalho é concluído no Capítulo 6, onde é feita também uma descrição das contribuições do trabalho. O Apêndice A traz exemplos de algumas das refatorações de bancos mais aplicáveis ao projeto. 


\section{Capítulo 2}

\section{Processo Tradicional de Construção do DW}

Segundo Christopher Adamson [1], o DW existe para responder às questões que as pessoas têm sobre o negócio. Esta função contrasta com o propósito dos sistemas transacionais, mostrando a necessidade de que a estrutura destes dois sistemas seja diferente. Os três textos de Haisten [22] mostram que, ainda na década de 70, pesquisadores do MIT (Massachusetts Institute of Technology) iniciaram pesquisas para encontrar uma estrutura de dados otimizada para fins analíticos. Este foi o primeiro estudo onde houve um consenso quanto à necessidade de separar fisicamente as ferramentas operacionais das ferramentas analíticas. Tanto suas bases de dados quanto os seus princípios de projeto deveriam ser diferentes.

Historicamente o conceito do DW é marcado pelo trabalho contínuo de empresas e de pesquisadores que buscaram desenvolver soluções adequadas a um banco de dados analítico. A IBM foi uma destas empresas, com diversos produtos [22,51] criados a partir de 1979 para atender demandas analíticas em um ambiente separado dos ambientes transacionais, poupando a limitada capacidade de processamento dos computadores da época. Outros autores também se destacaram, como Inmon [26] que, em 1991, apresentou seus conceitos e seu processo de engenharia de DW e, mais recentemente, Ralph Kimball $[35,38]$ apresentou outras propostas de historização de dados e também um processo de engenharia próprio.

As duas propostas tradicionais de engenharia, de Inmon e de Kimball, concordam que o desenvolvimento iterativo de DW é o mais adequado mas, para Inmon, este conceito não é seguido à risca pois seu processo pede que, inicialmente, seja feito um modelo completo da corporação e, também, que toda a infra-estrutura esteja inicialmente preparada. Assim, os ciclos evolutivos de seu método não cobrem aspectos de planejamento e de evolução corporativa. Em contrapartida, Kimball define o DW como a união de todos os seus data marts $^{1}$ e sua abordagem "iterativa" é centrada na construção de um data mart de cada vez, com a infra-estrutura e a modelagem voltadas apenas para a iteração. A abordagem de Kimball é a que será utilizada a partir de agora, pois sua estrutura de engenharia é mais facilmente adaptável aos propósitos do trabalho e, apesar de os dois métodos apresentarem

\footnotetext{
${ }^{1}$ Um data mart é um ambiente analítico derivado do DW e voltado a alguma área de negócio específica.
} 
o mesmo problema, relativo principalmente ao tamanho do escopo, o método de Kimball não exige nenhuma definição ou estruturação inicial completa e o seu conceito de trabalhar um data mart de cada vez também favorece uma redução do escopo, pois o ambiente inicial de trabalho já é segmentado por departamentos.

O desenvolvimento de um DW tem características diferenciadas e as suas atividades diferem das atividades de um sistema de software tradicional. A segunda edição do livro de Kimball "The Data Warehouse Lifecycle Toolkit" [38], apresenta um método de engenharia completo, muito utilizado e eficiente no desenvolvimento deste tipo de projeto. A Figura 2.1 descreve o fluxo deste método, que será explicado em detalhes ao longo deste capítulo.

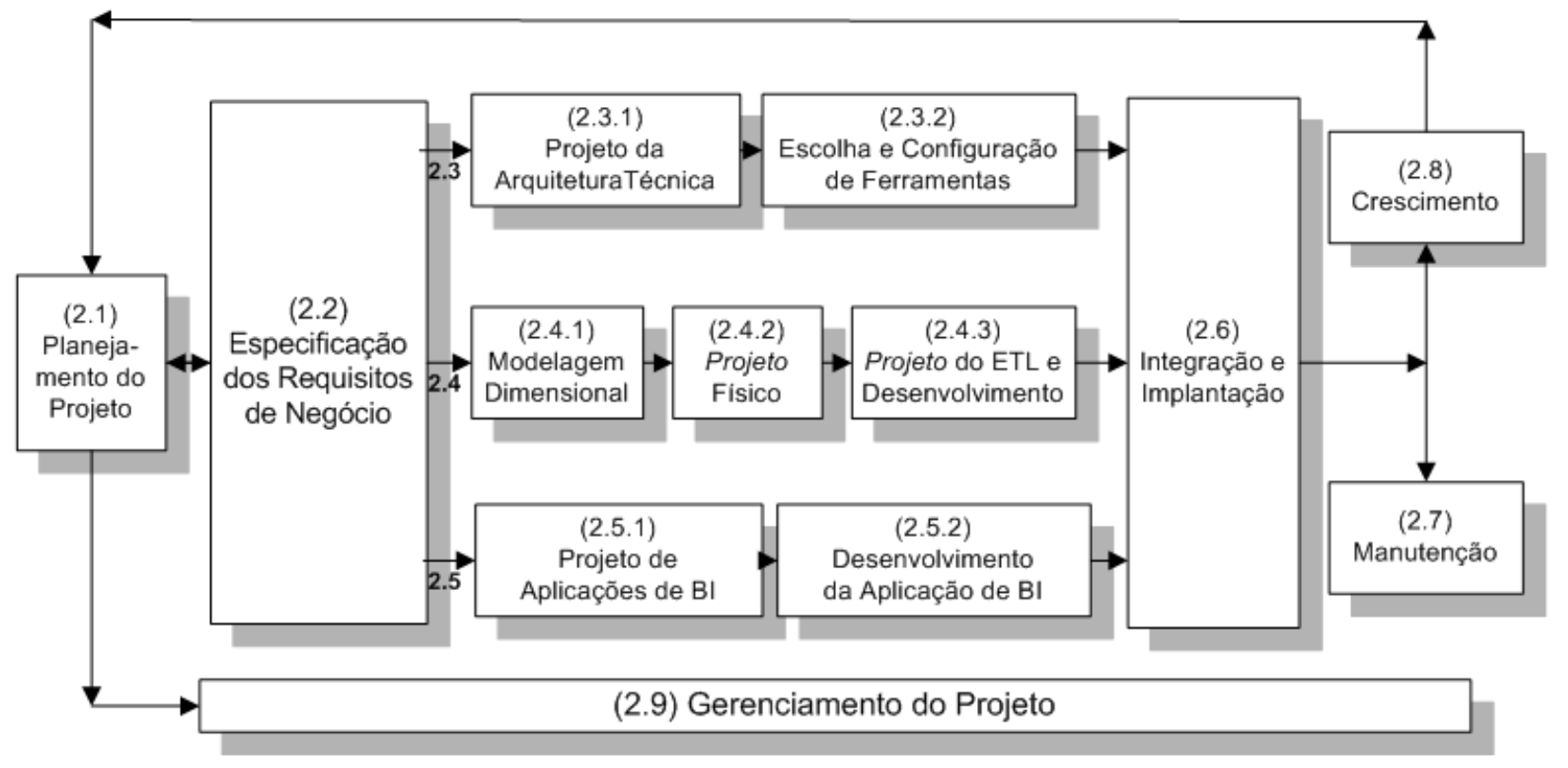

Figura 2.1: Processo de engenharia de DW segundo Kimball [38]

Os passos descritos no método de Kimball são necessários e suficientes para a implementação de um DW corporativo e são amplamente aceitos pelo mercado [22] desde o lançamento da primeira edição de seu livro [37]. Além disso, o método de Kimball tem um caráter iterativo e defende que a construção do DW seja incremental, focado na construção de cada data mart e na contínua integração entre eles.

\subsection{Planejamento do Projeto}

O desenvolvimento de um DW começa com o planejamento inicial do projeto. Há uma seqüência básica de itens para execução deste início de trabalho e a Tabela 2.1 resume estas atividades.

O planejamento começa por uma criteriosa análise do ambiente onde o DW será desenvolvido, 
Tabela 2.1: Atividades na fase inicial do projeto

\begin{tabular}{|l|l|}
\hline Atividade & Descrição \\
\hline $\begin{array}{l}\text { Análise inicial do ambi- } \\
\text { ente }\end{array}$ & Evitar problemas estruturais em fases avançadas do desenvolvimento \\
\hline $\begin{array}{l}\text { Escopo e data de en- } \\
\text { trega }\end{array}$ & $\begin{array}{l}\text { Definir um escopo mínimo que traga algum valor à empresa, justifi- } \\
\text { cando seus custos. Uma data prevista de entrega é importante para } \\
\text { formalizar o compromisso. }\end{array}$ \\
\hline Montagem da equipe & $\begin{array}{l}\text { A equipe de desenvolvimento é montada e seus membros são inte- } \\
\text { grantes de quatro categorias: Equipe gerencial, equipe de desenvol- } \\
\text { vimento, equipes especiais e consultores. }\end{array}$ \\
\hline $\begin{array}{l}\text { Cronograma de ativida- } \\
\text { des }\end{array}$ & $\begin{array}{l}\text { Um cronograma com as atividades da iteração corrente deve ser de- } \\
\text { senvolvido, com as datas estimadas para cada atividade, ou um in- } \\
\text { dicador de "atividade futura". }\end{array}$ \\
\hline Plano de comunicação & $\begin{array}{l}\text { O gerente de projeto estabelece um plano de comunicação para a } \\
\text { equipe, definindo as freqüências das reuniões, a duração de cada uma } \\
\text { e quais integrantes devem participar. }\end{array}$ \\
\hline
\end{tabular}

pois esta é a melhor forma de garantir que o DW terá os requisitos básicos para ser bem sucedido, evitando a realização de gastos e esforços em um projeto que não tenha boas condições estruturais. Os principais itens a serem analisados antes de iniciar o projeto são:

- Apoiadores: o projeto precisa de apoio gerencial. Pessoas com poder político que enxerguem os benefícios que serão trazidos pela maior qualidade no acesso às informações, característica básica do DW. Estas pessoas apoiarão o desenvolvimento, pois elas são capazes de entender os benefícios de longo prazo trazidos pelo projeto, ignorando os problemas de curto prazo e auxiliando em problemas que surgem ao longo do desenvolvimento.

- Qualidade estrutural: o DW utiliza como fonte as bases transacionais e é imperativo ao projeto que haja uma boa qualidade estrutural nestes sistemas. Se as bases transacionais não podem gerar os arquivos necessários, ou a qualidade destes arquivos é baixa, ou há tantos problemas com o ambiente transacional a ponto de causar prejuízo à base analítica, então estes pontos devem ser discutidos, pois todo o trabalho realizado pode ser comprometido em fases posteriores.

- Motivação na empresa: a motivação é importante pois, em um projeto bem sucedido, é comum que haja algum fator no ambiente da corporação que o apoie para gerar resultados positivos. Este fator pode ser um simples senso comum de urgência por uma solução de maior qualidade, pode ser a aquisição de uma empresa por outra, gerando exigências competitivas internas, ou mesmo uma crise que obrigue os gestores a terem uma visão mais ampla dos problemas. Independente do fator motivador, é importante que exista um e que ele favoreça o sucesso do DW na empresa. 
Feita esta análise preliminar, o próximo passo é a determinação do escopo do projeto. Há características simples mas importantes que devem estar no escopo, um documento cujo foco deve estar sempre voltado aos requisitos de negócio e, para maior eficácia, é importante uma colaboração direta entre a equipe de tecnologia de informação (TI) e a equipe de negócios. Por fim, o escopo deve ter funcionalidades suficientes para agregar valor ao projeto, ao menos para justificar o investimento realizado nesta fase de trabalho mas buscando superar estas expectativas.

É importante documentar bem as definições estabelecidas no escopo, que deve ser aprovado por todos os envolvidos mas, apesar desta aprovação, o escopo não é estático e pode ter itens alterados, adicionados ou removidos por razões diversas, ao longo de todo o projeto. Para isso é necessário que os membros das equipes de TI e de negócios estejam de acordo com as alterações no escopo do trabalho, possibilitando também uma visibilidade técnica dos impactos da alteração.

A montagem da equipe é o passo seguinte e há diferentes papéis a serem preenchidos.

- Nível gerencial

A equipe gerencial é que toma as decisões, garante o orçamento do projeto e é a principal interessada nos resultados finais do DW. É formada pelo diretor do projeto, pelos apoiadores, pelo gerente de projeto, pelo chefe de projeto e pelo líder de negócio do projeto.

- Equipe de desenvolvimento

Quem efetivamente implementa a solução é a equipe de desenvolvimento, composta por: analista de negócio, analista de qualidade, arquiteto de dados, administrador da base de dados (DBA), administrador de metadados, desenvolvedor ETL ${ }^{2}$ e o desenvolvedor de BI.

- Equipes especiais e consultores

São times especializados que têm um escopo de trabalho bastante limitado dentro da equipe como, por exemplo, um estatístico ou um especialista de testes. Eles podem participar do projeto como equipes contratadas ou como consultores especialistas, que geralmente ficam na equipe por períodos mais curtos, para aplicar suas habilidades na resolução de problemas ou para trabalhar em fases atrasadas.

Definida a equipe, é preciso fazer um cronograma de atividades, com detalhamento das tarefas, data de previsão de término e recursos alocados na realização de cada uma. O cronograma deve deixar claro apenas se as datas são "estimativas" (aconselháveis quando não há clareza do grau de dificuldade da tarefa) ou um "compromisso" (uma data fechada).

Por fim, o plano de comunicação é definido pelo gerente do projeto. Estão na lista de definições: a periodicidade das reuniões que serão efetuadas, quem participará de cada uma e qual a

\footnotetext{
${ }^{2}$ ETL é a sigla para o processo de Extração, Transformação e Carga
} 
duração prevista destas reuniões. Além disso, este plano de comunicação deve trazer também o fluxo de comunicação entre os desenvolvedores e os analistas de negócio (que precisam acompanhar apenas informações mais resumidas do andamento do projeto).

\subsection{Especificação de Requisitos de Negócio}

A especificação de requisitos é um dos pontos mais importantes de todo o projeto de DW pois suas definições direcionam o trabalho de todas as equipes nas etapas posteriores. Quando o usuário tiver acesso ao DW, o resultado final deve obrigatoriamente atender suas expectativas de negócio e, por isso, é um fator chave especificar corretamente aqui as suas necessidades.

Assim, os usuários de negócio e os requisitos que eles desenvolvem têm influência sobre praticamente todo o projeto de DW [36], nesta etapa que demanda um alto conhecimento semântico da organização, das regras de negócio e das estratégias da empresa. A especificação de requisitos deve estar alinhada com aspectos culturais da corporação e, para isso, é preciso envolvimento de pessoas que conheçam bem a empresa, desde os especialistas de negócio aos gestores e demais colaboradores que participam do processo de tomada de decisão.

Em todos os sistemas de software, há um grande esforço por parte dos projetistas na elaboração da especificação de requisitos. Segundo Lorentz [40] trata-se de uma tarefa dispendiosa em termos de tempo e dinheiro, que envolve diversos setores da empresa e que movimenta muitas pessoas. Por esta razão, há uma tendência natural de "simplificar" ou "encurtar" esta fase do projeto, o que pode ser uma atitude perigosa pois, dada sua importância, a especificação deve ser executada com muito critério.

Ao longo da coleta de requisitos, os projetistas devem se preocupar com diversas questões, como por exemplo: Como funciona o negócio da empresa? O que é necessário e o que é desejável? Quais são as hierarquias do negócio? Como funciona hoje o ambiente dos usuários e como seria o ideal? Quais os níveis de detalhes da informação e quais são necessários? Qual a necessidade de dados históricos? Ao final, deve haver uma boa compreensão das necessidades da empresa, para que os projetistas possam desenvolver os passos subseqüentes na construção do DW.

Quanto à classificação dos tipos de requisitos, eles podem ser subdivididos em dois grupos: requisitos funcionais e requisitos não-funcionais. Os requisitos funcionais descrevem as necessidades da organização no nível do negócio, com as regras e características reais que guiam suas atividades. Já os requisitos não-funcionais têm um papel mais técnico e abrangem características operacionais como facilidade de uso, desempenho, segurança, etc.

Após a coleta de requisitos, há três seqüências de atividades que podem ser executadas em paralelo, segundo o processo de engenharia apresentado na Figura 2.1. Estas seqüências são descritas a seguir. 


\section{3 - Trilha da Tecnologia}

Muitas são as tecnologias envolvidas em um projeto de DW e cada fase do processo tem necessidades de infra-estrutura distintas. Esta trilha de tecnologia é a seqüência de passos necessários à implantação da infra-estrutura técnica. Assim, o desenho técnico do ambiente precisa ser projetado, ferramentas e utilitários devem ser definidos e tudo precisa ser devidamente configurado e testado. A trilha da tecnologia é composta pelas atividades descritas a seguir.

\subsubsection{Projeto da Arquitetura Técnica}

O projeto da arquitetura técnica dá uma resposta complementar no projeto de DW pois, enquanto na especificação de requisitos a pergunta é "O que é preciso fazer?", nesta etapa do processo a questão é "Como será feito?". Todo o conjunto de tecnologias que serão necessárias quando o DW estiver em produção e em uso devem ser definidas, incluindo, por exemplo, as ferramentas, os utilitários e as plataformas necessárias para que o fluxo dos dados ocorra.

Este fluxo de dados se inicia no acesso às fontes transacionais, seguido por um processo de ETL para carga nas bases do DW e do servidor de apresentação para, então, chegar ao seu destino final, que são as aplicações de BI. Neste fluxo de desenvolvimento há duas frentes de trabalho [38]: As equipes de back room, que trabalham nos bastidores do processo, na preparação dos dados para carga ETL, passo em que os dados não são acessíveis aos usuários, e as equipes de front room, responsáveis pelo desenvolvimento da interface pública do DW, que é a camada de apresentação.

No front room as equipes trabalham para dar visibilidade corporativa aos dados, disponibilizando a informação ao máximo, em formatos que facilitem o trabalho dos times que o utilizarão. Por esta razão, aplicações de BI são importantes na fase de apresentação, pois esta camada permite ocultar as complexidades dos dados, facilitando o uso da base.

Para os fins deste projeto técnico de arquitetura, devem ser estudadas e definidas todas as possíveis ferramentas que serão utilizadas nestas duas fases do processo. Tanto o back room quanto o front room podem fazer uso de complexas ferramentas, que podem ser caras e precisam ser cuidadosamente escolhidas.

No back room há, por exemplo, o processo de ETL, responsável por cargas pesadas e constantes. No processo de ETL pode-se decidir, simplesmente, por não utilizar nenhuma ferramenta e implementar manualmente todas as extrações com as ferramentas do próprio gerenciador de banco de dados, construindo scripts $\mathrm{SQL}^{3}$ para realizar todo o processo de extração, transformação e carga. Esta solução é sem dúvida mais barata, mas tem um custo de manutenção muito maior do que utilizar uma ferramenta de ETL mais poderosa, com funções gráficas por exemplo. Uma análise de desempenho tem também grande importância na escolha das possíveis soluções de ETL do projeto.

\footnotetext{
${ }^{3}$ Structured Query Language
} 
Já no front room, existem diversas possíveis soluções de BI e é natural implementar gradualmente estas soluções, para que os usuários aprendam a usar e tirar valor de uma de cada vez. Dentre as possíveis soluções de BI estão:

- Acesso direto ao DW por consultas

- Relatórios pré-definidos

- Relatórios analíticos

- Dashboards e Scorecards

- Mineração de dados e modelos analíticos

Há muitas possíveis aplicações para cada uma destas soluções e, enquanto algumas são comercializadas por grandes empresas, outras soluções podem ser desenvolvidas internamente. A realização de um estudo é importante para definir quais as vantagens e desvantagens de cada uma delas, para escolher as ferramentas mais adequadas e mais alinhadas aos objetivos da empresa.

Os metadados são um tópico importante na definição da arquitetura técnica, pois são uma rica fonte de informações sobre o que há no DW. A maior complexidade deste tema está no fato de que as diferentes soluções envolvidas no projeto do DW costumam ter seus próprios repositórios de metadados, o que dificulta a existência de um único repositório integrado para todos os metadados.

A integração de todos os metadados em um único repositório é considerada por Kimball uma solução ideal [38] pois: (1): Facilita as análises dos impactos que evoluções ou mudanças em algumas partes do sistema podem causar em outras como, por exemplo, as alterações que podem ser geradas no processo ETL ou nos relatórios de front end quando ocorre alguma alteração nas bases transacionais. (2): Oferece uma melhor estrutura para auditoria e documentação das informações do DW e (3): Torna mais simples o processo de controle de qualidade e de manutenção dos metadados, uma conseqüência natural da centralização.

Finalmente, é feita a publicação das informações para aqueles que utilizarão o DW e os dados devem ser protegidos para que cada usuário acesse apenas as informações que tiver permissão. A segurança é um tema muito complexo e, por esta razão, soluções que ajudem na segurança são fundamentais e devem ser utilizadas. No entanto, deve haver um nível de tolerância, pois é muito difícil garantir uma segurança perfeita no sistema e esta preocupação pode desviar o foco dos principais objetivos do DW. 


\subsubsection{Escolha e Configuração de Ferramentas}

Esta etapa de desenvolvimento se subdivide em dois eixos principais: A criação do plano de arquitetura, que tem como meta a efetiva implantação da arquitetura de todo o ambiente e, a seleção de produtos, cujo objetivo é selecionar as ferramentas mais adequadas a cada necessidade identificada no plano de arquitetura.

A criação do modelo de arquitetura é um processo bastante dependente da especificação de requisitos de negócio pois todas as etapas de trabalho na montagem da arquitetura visam atender o que o cliente considera mais importante. Equipes que trabalham no back room podem trabalhar paralelamente com as equipes do front room nas diversas etapas do processo, para uma posterior integração destes trabalhos antes de sua entrega.

A criação do plano de arquitetura resulta na criação de um documento descritivo, estruturado ao longo de passos como os descritos por Kimball [38], que tem a sua estrutura dividida em resumo, metodologia, requisitos de negócio e implicações na arquitetura, visão geral da arquitetura, detalhes dos elementos da arquitetura eprocesso de desenvolvimento da arquitetura.

A seleção de produtos é a fase seguinte, pois é necessário escolher os produtos que serão comprados para o projeto e manter o foco nas necessidades do negócio é a regra básica para avaliação de produtos de hardware, $\mathrm{SGBD}^{4}$, ferramenta de ETL e ferramentas de BI.

Além do foco constante no negócio, é importante avaliar as opções de produtos disponíveis, conduzindo uma pesquisa de mercado e desenvolvendo um processo de comparação através de uma matriz com as tarefas que serão executadas em relação ao potencial das ferramentas de mercado para cada tarefa. Além disso, entender o processo de compra é importante, para realizar uma pesquisa alinhada com a equipe de compras da empresa. Finalmente, deve-se fazer uma pré-seleção dos produtos mais adequados, para possibilitar a avaliação dos melhores candidatos em pesquisas mais aprofundadas, com trials, protótipos, etc.

\section{4 - Trilha dos Dados}

Descreve o caminho dos dados, desde o desenvolvimento do modelo dimensional e físico, até o processo de extração, transformação e carga no DW. A trilha dos dados é composta pelas fases de desenvolvimento descritas a seguir.

\footnotetext{
${ }^{4}$ Sistema Gerenciador de Banco de Dados
} 


\subsubsection{Modelagem Dimensional}

O DW deve representar fielmente a maneira como os analistas enxergam o negócio da empresa e o seu modelo deve refletir esta expectativa. A técnica mais utilizada para um modelo de dados que atenda esta necessidade é a Modelagem Dimensional. Quando bem definido, o modelo dimensional oferece grandes vantagens para as áreas de negócio, apoiando e otimizando todo o processo de tomada de decisões [28].

Este modelo tem duas grandes vantagens em relação a modelos normalizados. A primeira é a sua maior facilidade de compreensão pelos usuários, pois o modelo de negócio é mapeado da maneira como os usuários de negócio o enxergam, fácil de entender e simples, mas sem ser simplista. A outra vantagem é que tem melhor desempenho em consultas analíticas, pois muitos joins são evitados com a sua utilização [38].

O modelo dimensional agrega muito valor ao projeto de DW e é desenvolvido no início da trilha dos dados. A implementação das tabelas de dimensões e das tabelas de fatos utilizam alguns conceitos que podem trazer facilidades posteriores. O modelo estrela é uma estrutura defendida por Kimball, e é apresentado na Figura 2.2, que traz uma Tabela de Fatos Venda e quatro Tabelas de Dimensões: (Tempo, Produto, Cliente e Loja).

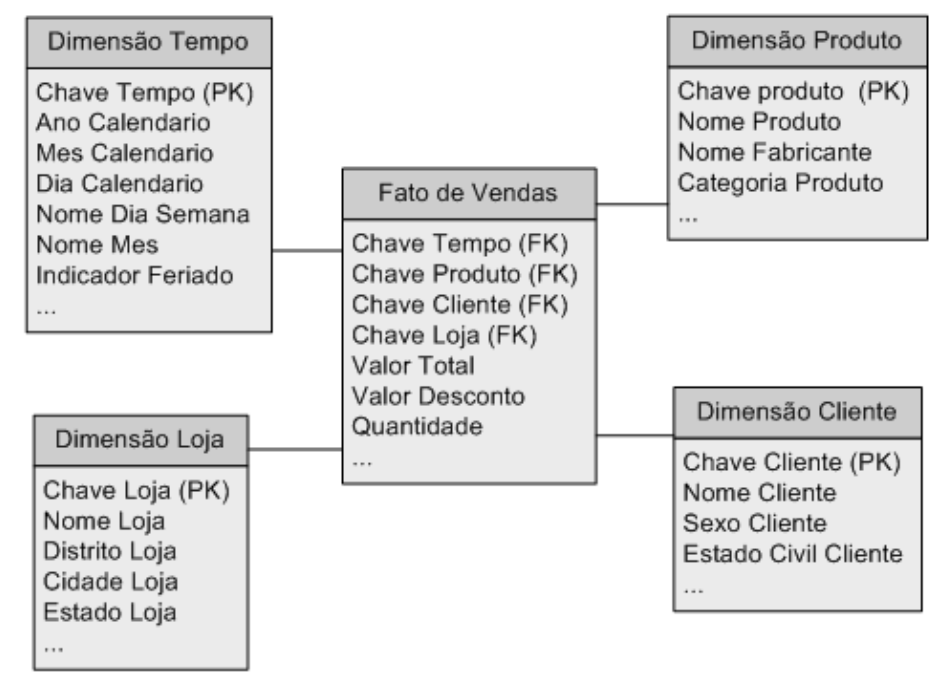

Figura 2.2: Exemplo de modelo dimensional: Esquema Estrela

As tabelas de dimensões são as representantes textuais das tabelas de fatos. Elas crescem pouco e podem ter muitas colunas descritivas. Além destas colunas, uma dimensão precisa também de uma chave primária, para joins com as tabelas de fatos ligadas a ela. Segundo Kimball [36], a qualidade de um DW pode ser medida pela qualidade de suas dimensões, que são a porta de entrada do DW e a principal interface do usuário com os dados. 
No modelo de dados estrela, as dimensões podem ter hierarquias por atributos da própria dimensão. Uma dimensão de produtos, por exemplo, pode possuir um atributo "Fabricante" e depois outro chamado "Categoria", onde ambos representam hierarquias dentro da dimensão. Há uma replicação consentida dos registros, para evitar a normalização do modelo. Contudo, existe também a possibilidade de que ocorram hierarquias, originando o modelo floco de neve, também conhecido por snowflake, que aplica um maior grau de normalização nas dimensões, a fim de reduzir o armazenamento de dados redundantes [52]. Neste esquema as dimensões são normalizadas com uso de sub-dimensões, em que cada nível de hierarquia é armazenada em uma tabela diferente.

A seguir, seguem algumas características importantes das tabelas do modelo dimensional.

\section{- Datas e Tempo}

As dimensões de datas e de tempo são tratadas de maneira especial no DW, pois todas as tabelas de fatos podem ser vistas como observações temporais dos dados e, por esta razão, costumam ter ao menos uma Dimensão Data, que também pode ser chamada de Dimensão Tempo. No DW, a dimensão data deve ser capaz de suprir completamente a utilização de calendários externos, devendo possuir os atributos necessários para este fim, como indicadores de feriados, dia da semana, dia do mês, descrição da data, etc.

Quando possível, um nível de detalhamento em dias é adequado, para responder corretamente a um calendário, permitindo mapear eventos diários. Quando houver necessidade de um maior detalhamento temporal, pode ser utilizada uma Dimensão Hora do Dia para todos os possíveis horários do dia, com um nível de detalhamento de até segundos (aproximadamente 86.400 linhas).

\section{- Dimensões: Mudanças lentas}

As dimensões sofrem poucas alterações com o passar do tempo e, por esta razão, têm um conceito de evolução e de historização diferente das tabelas de fatos. As três principais técnicas para tratar historização de dimensões, conhecidas por SCD (slowly changing dimensions ou dimensões que mudam lentamente) são:

Tipo 1: sobrescrever os atributos que mudam, não realizando nenhuma historização para o valor antigo; Tipo 2: criar um novo registro idêntico ao registro que mudou, mas atualizando no registro antigo o atributo "data de validade" com o valor da data atual e mantendo esta data no novo registro em aberto e; Tipo 3: adicionar uma nova coluna na dimensão com o valor atual, migrando o valor antigo para uma coluna histórica e deixando ambos juntos na mesma linha.

Atualmente, discute-se uma nova forma de historização que é um Tipo 4, muito semelhante ao Tipo 2, mas no qual a historização da dimensão é realizada em uma tabela histórica, separada da dimensão principal. É um método útil principalmente quando a dimensão tratada for muito 
grande, pois na dimensão principal somente ficam os valores atualmente válidos e, para análises históricas, pode-se recorrer à tabela de historização.

\section{- Mini-Dimensões}

Algumas dimensões podem possuir atributos que distorçam o conceito de evolução lenta, causando uma alta quantidade de alterações, que causa prejuízos de desempenho e dificuldades de manutenção. Para contornar este problema, pode-se utilizar uma técnica chamada de "minidimensões", que consiste na separação dos atributos que sofrem evoluções mais constantes para uma dimensão menor e separada.

Um exemplo prático para esta técnica está na implementação da dimensão cliente, cujos dados demográficos (número de filhos, faixa etária, salário, telefone, endereço, estado civil, etc) mudam muito mais do que dados cadastrais (nome, sexo, CPF, data de nascimento, etc). Por isso, é uma boa estratégia separar fisicamente estes campos em duas tabelas, evitando uma grande duplicação dos campos mais estáveis. Pode-se utilizar um relacionamento direto entre a tabela de dimensão principal e a mini-dimensão para realizar estudos sem a utilização de uma tabela de fatos.

\section{- Dimensões Snowflaking}

A estrutura do modelo de dados estrela apresenta redundância de dados nas suas dimensões. Esta propriedade é intencional, pois o modelo defende que os ganhos com simplicidade e clareza superam as vantagens que um modelo normalizado poderia trazer.

Dimensões snowflaking resolvem o problema da redundância de dados nas dimensões, mas aumentam a complexidade de compreensão e de navegação do modelo. Na maioria dos projetos de DW, as tabelas de fatos são responsáveis por uma utilização superior a $90 \%$ do espaço em disco [38] e o restante é usado pelas dimensões. Por esta razão o modelo snowflaking, que altera a estrutura de armazenamento das dimensões, traz um ganho muito limitado de disco e, na maioria dos casos, não é uma opção muito recomendada devido ao aumento de complexidade que insere no modelo.

A tabela de fatos é a principal tabela do modelo dimensional. Ela é responsável pelo armazenamento de todas as métricas e chaves relativas a um fato ocorrido. Os campos de uma tabela de fatos são mais úteis quando numéricos e aditivos [38], pois campos descritivos podem ser encontrados nos atributos das dimensões. Em uma tabela de fatos há basicamente dois tipos de campos: chaves estrangeiras, utilizadas para referenciar as dimensões e os campos de fatos, ou métricas, que têm as "medidas" a serem analisadas (valores, quantidades, etc). Quanto à aditividade, as colunas da tabela de fatos devem ser cuidadosamente definidas pelos projetistas e podem ser classificadas em três grupos: aditivas, semi-aditivas e não-aditivas. 
- Métricas aditivas: Uma métrica é aditiva quando faz sentido realizar análises de soma nesta métrica ao longo de qualquer dimensão. Um campo de "Valor da Compra" é um exemplo de métrica aditiva, uma vez que pode ser somado em qualquer dimensão de análise.

- Métricas Semi-Aditivas: Estas métricas permitem ser somadas ao longo de algumas dimensões apenas, ou seja, há dimensões em que a soma faz sentido e há dimensões em que não faz. Por exemplo, um campo de "Saldo Bancário" pode ser somado por banco, para saber o disponível total do cliente em um determinado dia considerando todos os seus bancos, ou ainda, somar o saldo de todos os clientes em alguma agência bancária específica, mas não faz sentido somar o saldo de um mesmo cliente ao longo do tempo.

- Métricas Não-Aditivas Estas métricas não podem ser somadas em nenhuma dimensão. Um bom exemplo deste tipo de métrica são valores percentuais, como por exemplo a \% de margem de lucro. Não faz sentido somar a \% de margem de lucro em nenhuma dimensão de análise, pois a soma de um valor percentual não é uma informação útil.

As métricas aditivas são as mais adequadas pois, como podem ser somadas livremente, sua utilização em consultas de agregação não tem nenhuma restrição no DW. Quanto ao nível de detalhamento da tabela de fatos, há três níveis de detalhamento, ditos fundamentais, para estas tabelas [38], que são:

\section{- Os Três Níveis Fundamentais}

1. Detalhamento transacional: é o nível de maior detalhamento, onde os dados refletem da maneira mais completa possível a verdade no momento em que a transação ocorreu. As tabelas de fatos neste nível costumam ter um grande número de dimensões associadas.

2. Instantâneo periódico: com periodicidade definida, são tiradas "fotografias" das métricas de desempenho e de suas dimensões. Estas fotografias são armazenadas de maneira incremental, ou seja, uma vez inserida, a linha não deve sofrer alterações. Este nível tem um número menor de dimensões e um grande potencial para análise de desempenho, oferecendo uma capacidade analítica ainda maior quando combinadas com tabelas de detalhamento transacional.

3. Instantâneo incremental: nesta estrutura também são tiradas "fotografias" mas, ao invés de acumulados, os dados são constantemente atualizados no registro do primeiro fato ocorrido. Esta opção de carga é utilizada quando há um processo com fluxo bem definido, com várias etapas, que não pode ser muito complexo e nem apresentar ciclos, pois todos os campos de todas as etapas já estão na tabela desde a sua primeira ocorrência, mas com valores "genéricos" trazidos na primeira vez, que devem ser atualizados de acordo com a evolução do processo no fluxo. 
Ao selecionar os campos de uma tabela de fatos, é importante garantir que todos os campos que serão inseridos na tabela têm um significado analítico correto em seu nível de detalhamento [38]. Por isso, quando um desenvolvedor tiver que adicionar uma métrica em uma tabela de fatos com granularidade não compatível, ele deve buscar uma forma de manter esta integridade de conceito, sendo necessário realizar alguma transformação na métrica para garantir que isso ocorra.

Em situações assim, uma primeira opção é levar todas as variáveis ao nível de maior detalhamento, aplicando alguma técnica de distribuição do valor da métrica ao nível de detalhamento da tabela. Esta solução exige uma decisão funcional sobre o que fazer com as métricas em maior nível de agregação. Pode-se, por exemplo, alocar de maneira ponderada nas linhas ou, simplesmente, dividir de maneira uniforme os valores da métrica nas linhas em que ela deve estar presente (de acordo com o nível de granularidade da tabela de fatos). Quando a métrica não permitir tal solução, é necessário separá-la fisicamente em alguma tabela de fatos compatível.

\section{- Tabelas de fatos sem fatos}

Há tabelas de fatos em que não faz sentido ter métricas de análise e a existência de um registro pode ser descrita apenas pelas dimensões que materializam o fato ocorrido. Um exemplo deste caso é uma tabela para observação de presença de alunos em aulas, cuja existência busca responder meramente a perguntas como: "Quantos alunos assistiram a aula de determinado professor em um determinado periodo de tempo?".

\section{- Tabelas de fatos consolidadas}

Cada processo de negócio da empresa tem seu próprio data mart, cujos modelos de dados são separadamente chamados de temas de trabalho (ou subject areas). Assim, como exemplo, se uma empresa possui um processo de aquisição de matéria prima, uma tabela de fatos e as suas correspondentes dimensões estariam presentes em um tema de trabalho deste processo de negócio.

Uma tabela de fatos consolidada pode ser construída para facilitar a análise conjunta de métricas pertencentes a tabelas de fatos em subject areas distintas e à combinações delas, em um nível de detalhamento que faça sentido em relação às tabelas origem. Pode-se, por exemplo, juntar em uma tabela consolidada por mês a informação de "risco previsto" no mês e de "risco observado", para uma comparação imediata entre estas duas variáveis.

\subsubsection{Projeto Físico}

Após a modelagem dimensional, o próximo passo da trilha de dados é o projeto físico do banco. A Figura 2.3 traz uma visão geral dos passos executados nesta fase do trabalho, descritos a seguir. 


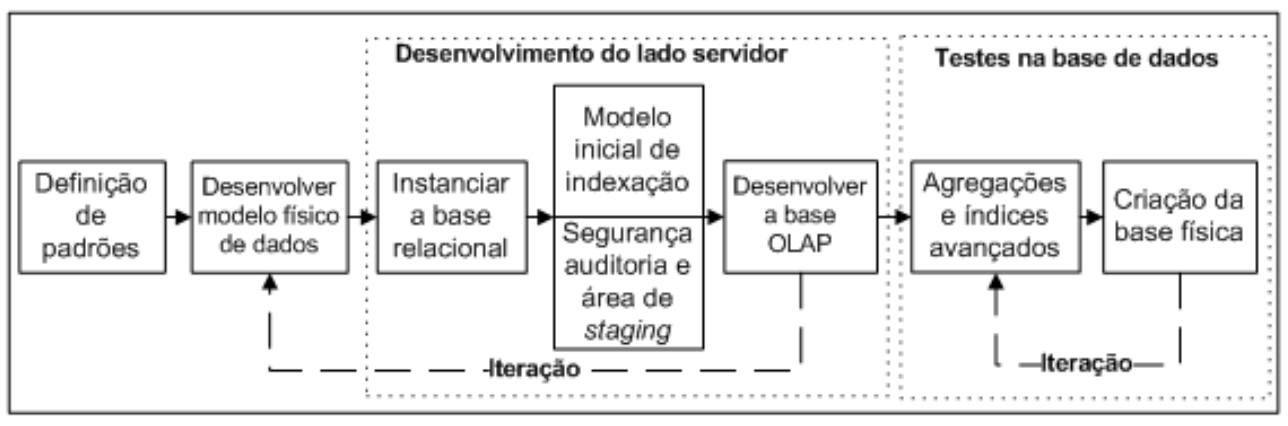

Figura 2.3: Projeto físico da base

- Definição de padrões: os padrões de desenvolvimento são definidos para os diversos componentes do sistema de DW e de BI. Padronizar nomes e a localização dos arquivos de desenvolvimento, estabelecer um método de controle de versões, etc.

- Desenvolver o modelo físico de dados: o modelo físico pode ser parecido com o modelo lógico, mas faz um maior detalhamento e mostra a real estrutura que será implementada na representação do modelo lógico.

- Instanciar a base relacional: uma base de testes deve ser instanciada, para que os processos de ETL possam ser desenvolvidos. Estimativas de tamanhos também são importantes para uma boa definição da estrutura inicial da base.

- Modelo inicial de indexação de dados: o plano de indexação inicial, aumenta o desempenho das consultas no DW e diferentes tipos de índices podem ser usados para as dimensões e para as tabelas de fatos do ambiente.

- Segurança, auditoria e área de staging: quando possível, deve-se desenvolver um processo para controle de acesso e de utilização do DW.

- Desenvolver a base OLAP: a utilização de cubos analíticos com tecnologia OLAP pode incrementar muito o desempenho analítico das ferramentas de BI. A principal diferença entre esta etapa e o desenvolvimento da base física relacional está na maior preocupação com as hierarquias existentes entre os campos das dimensões, característica posteriormente necessária à manipulação analítica de drill up e drill down nas hierarquias.

- Agregações: agregações são uma forma eficiente para aumentar o desempenho no acesso às tabelas do DW. Por isso, são definidas as melhores agregações no contexto do projeto, como as agregações serão implementadas e como as tabelas agregadas serão mantidas e atualizadas.

- Criação da base física: para finalizar esta etapa, deve ser criada a instância da base de dados, ela precisa ser configurada e todos os seus scripts têm que ser salvos e versionados. 
Há diversos recursos no projeto físico do banco que não são visíveis no modelo lógico, mas que são muito importantes para um bom projeto de DW como, por exemplo, uma eficiente utilização de visões, como descrito no trabalho de Isabel Cristina Italiano [29]. Em um banco de dados, uma visão é uma camada intermediária entre os usuários e as tabelas físicas, e pode ser definida tanto por uma simples consulta SQL feita diretamente no conjunto de tabelas fontes, como pode também ser uma visão materializada, ou seja, ter seu conjunto de dados fisicamente armazenados no banco.

O uso de visões permite, sem trabalho extra no processo de carga, restringir o acesso de usuários a um número limitado de campos, além de facilitar a manutenção do banco e poder impactar muito positivamente o desempenho de consultas. As visões ainda ajudam a driblar algumas dificuldades que um banco relacional pode apresentar em análises no modelo dimensional, como a necessidade de

joins entre uma tabela de fatos com filtros de datas em campos diferentes (a seção 5.4 discute este problema com a criação de uma view para cada um dos campos de datas do modelo dimensional).

\subsubsection{Projeto do ETL e Desenvolvimento}

No trabalho de Kimball são descritos trinta e quatro subsistemas que, juntos, definem as diversas frentes de trabalho em um ambiente de desenvolvimento ETL. Estes subsistemas se dividem em quatro subcategorias, que são extração de dados, limpeza e padronização dos dados, entrega dos dados para apresentação e gerenciamento do ambiente de ETL. Abaixo está um resumo de cada uma destas etapas.

\section{Extração de dados:}

Seguindo a especificação de requisitos, os analistas devem realizar uma investigação nos dados relevantes de tabelas candidatas a fontes do DW, para uma melhor compreensão dos dados contidos nestas tabelas. O passo seguinte está em escolher as formas mais adequadas para identificar modificações nos dados e todos os diferentes tipos de alterações precisam ser considerados, como remoções, edições e inserções de novos registros. A última definição desta etapa de extração é quanto ao método de disponibilização dos arquivos fontes, que pode ser feita com alguma periodicidade (diária por exemplo) ou por acesso direto, por streamming, quando as tabelas do ambiente transacional são acessadas diretamente, o que em geral é feito para dar dinâmica no processamento de informações críticas.

\section{Limpeza e padronização dos dados:}

Esta segunda etapa do processo ETL é considerada crítica para o DW pois é aqui que ocorrem as transformações que mais agregam valor aos dados do ambiente analítico. Sistemas que garantem a qualidade dos dados, sua limpeza, a padronização das diferentes fontes em uma visão única e, por fim, a captura de erros ao longo do processamento, para rastrear os problemas ocorridos durante o ETL, são as principais atividades realizadas nesta etapa. 
Um sistema de limpeza dos dados fontes é o primeiro passo e, além do objetivo de identificar e limpar dados sujos, tem a importante missão de diagnosticar rapidamente problemas nos dados, evitando que dados ruins possam chegar aos relatórios gerenciais. Para realizar esta difícil tarefa, a proposta para um bom controle da qualidade dos dados está no uso de cenários de qualidade, em que cada cenário representa um conjunto de testes a serem executados. Kaufmann [34] descreve três categorias de cenários de qualidade, que são: os cenários de colunas, que testam os dados de uma única coluna isoladamente, os cenários estruturais, que testam os dados pelo cruzamento entre colunas, testando por exemplo a integridade entre diferentes arquivos fontes e, finalmente, os cenários de regras de negócio, que são os de maior complexidade, pois podem exigir testes de freqüência de valores, análises de variações mensais, etc.

Em um cenário de qualidade, deve-se tomar uma ação sempre que alguma anomalia for identificada, que pode ser abortar completamente o processo, o que exige intervenção manual para identificação e correção do problema, ou pode ser uma ação mais amena, como o lançamento de um alerta para os analistas e a marcação dos registros problemáticos, permitindo que o processamento continue sem interrupção. Esta ação é mais adequada por não exigir intervenção manual, permitindo a continuidade do processamento, devendo ser a opção adotada sempre que o problema identificado nos testes do cenário não for crítico. Na ocorrência de erros, Kimball [38] defende o uso de sistemas capazes de controlar e rastrear cada um deles.

O primeiro destes sistemas se baseia em um esquema próprio para a análise dos eventos de erros, em um modelo de dados dimensional, composto por uma tabela de fatos que armazene cada evento de erro, com dimensões analíticas que permitem rastrear o problema (por exemplo uma dimensão de tempo, dimensão de cenário de qualidade, dimensão que descreva o erro, etc). Outro sistema auxiliar é relacionado ao rastreamento de erros e a proposta é ter uma dimensão de auditoria ligada a todas as tabelas de fatos do DW, onde as informações de metadados na carga de um registro são armazenadas na dimensão. Neste caso, em uma carga sem nenhum erro, todos os registros das tabelas de fatos apontariam para o mesmo registro identificador de metadados na dimensão de auditoria. Quando houver um erro em alguma parte especifica na carga da tabela de fatos, um registro extra na dimensão é necessário para mapeamento do problema.

A fase de limpeza e padronização de dados se encerra com dois importantes sistemas: o primeiro deles busca garantir a deduplicação dos dados, para que as fontes heterogêneas não causem duplicação nas tabelas finais. O último sistema desta etapa é o sistema de padronização, que tem a tarefa de definir valores padronizados para colunas com o mesmo significado que tenham diferentes valores no ambiente transacional. O exemplo clássico de aplicação deste sistema é o campo "sexo", onde valores como " $\mathrm{F} / \mathrm{M}$ ", "M/H" e " $0 / 1$ " poderiam ocorrer em três sistemas fontes diferentes na identificação de sexo feminino e masculino e, neste caso, todos devem ser mapeados para um formato único no DW, por exemplo "F/M". 


\section{Entrega dos dados para apresentação:}

Esta fase do processamento ETL tem a função de carregar e manter as tabelas de fatos e as dimensões do ambiente analítico de acordo com as suas especificações e o primeiro subsistema descrito é o gerenciador de dimensões, responsável por manter as dimensões do DW. Os três tipos de evoluções descritos na Seção 2.4.1, chamados de SCD (slowly changing dimensions) devem ser considerados na implementação deste gerenciador, que obedece ao fluxo descrito na Figura 2.4, cuja descrição vai a seguir.

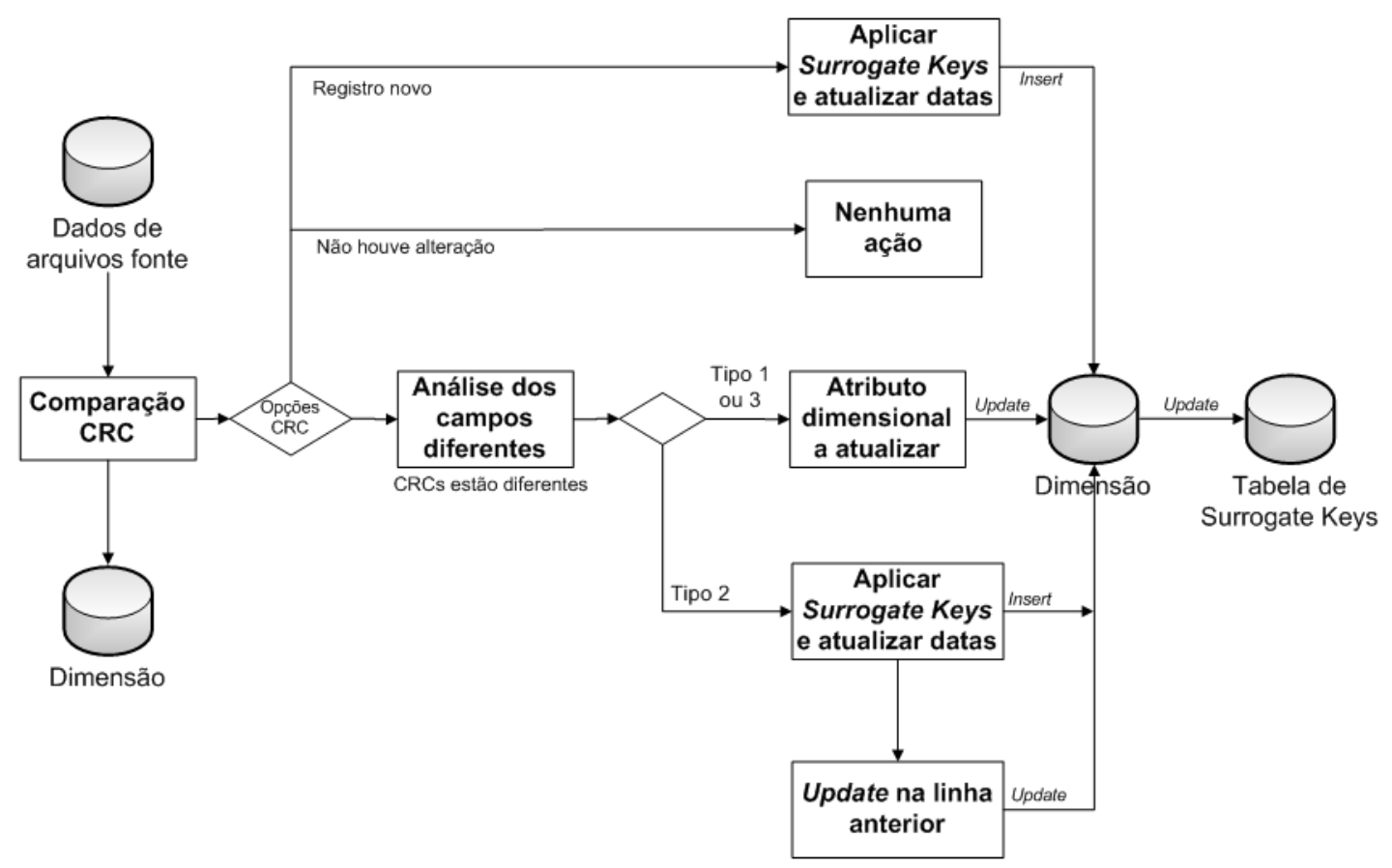

Figura 2.4: Fluxo do processamento ETL para manutenção de dimensões

Tipo 1: simples atualização na dimensão alterada. Exige cuidado com agregações que tenham sido feitas antes da atualização, pois elas devem ser refeitas. Este método é eficiente para correção de registros incorretos, pois não oferece historização de mudanças.

Tipo 2: é o método mais comum na atualização de uma dimensão. Adiciona-se uma nova linha na tabela, deixando uma coluna de validade em aberto. O registro anterior deve ter sua data de validade atualizada para a data do processamento. Desta forma, os registros de tabelas de fatos mantém sempre a referência para os valores dimensionais válidos na ocorrência do fato, e o histórico de alterações das dimensões é, portanto, armazenado.

Tipo 3: desenvolvido para mudanças pequenas, este método adiciona uma nova coluna na dimensão, com o valor anterior do atributo modificado, mantendo a coluna original com o valor mais atual. Este método é adequado para alterações que são previsíveis nas dimensões e em períodos de tempos não muito curtos. 
A implementação da dimensão do Tipo 4 não é descrita no texto acima ou na Figura 2.4 pois trata-se de uma especialização da evolução Tipo 2. O fluxo de ambas é exatamente o mesmo, mas o armazenamento final dos registros históricos da evolução Tipo 4 é realizado em uma tabela dimensional histórica separada. Este método é útil em tabelas muito grandes, onde o uso da evolução Tipo 2 pode gerar um problema de desempenho no acesso à dimensão.

Além deste gerenciador específico de dimensões convencionais, Kimball descreve três subsistemas auxiliares que o processo de ETL deve implementar para o processo de carga das dimensões. O primeiro deles é um gerenciador de Surrogate Keys, para atribuição de chaves nas dimensões durante a carga. O segundo é o gerenciador de hierarquias, importante no controle de estruturas hierárquicas e, por fim, o gerenciador de dimensões especiais, cuja responsabilidade é cuidar de dimensões que tenham necessidades diferentes de crescimento em relação aos métodos SCD, descritos na Seção 2.4.1. São exemplos de dimensões especiais as "dimensões de tempo" e as "mini-dimensões", apresentadas na discussão de modelagem dimensional da Seção 2.4 .

Outro importante subsistema na etapa de entrega de dados é o construtor de tabelas de fatos. Este subsistema é responsável pela lógica do processo de carga dos três tipos primários de tabelas de fatos descritos em 2.4.1, que são: as tabelas de detalhamento transacional, as de instantâneo periódico e as de instantâneo incremental e, para qualquer destes três tipos, é importante garantir a integridade referencial com as dimensões e um subsistema auxiliar é descrito mais adiante para este fim.

A tabela de fatos com "detalhamento transacional" permite uma visualização dos dados com maior nível de detalhes possível, pois cada transação representa um registro na tabela. Uma tabela carregada por "instantâneo periódico" oferece uma visão dos dados no final de um período e este tipo de carga permite uma fácil visualização da evolução dos dados entre períodos de tempo. Finalmente, o modelo de "instantâneos acumulativos" é bem aplicável em situações onde o processo tenha uma clara definição de início, meio e fim. Um exemplo deste processo é uma tabela de fatos para ordem de compras pela internet, quando uma compra precisa ser efetuada, depois deve ser paga e finalmente o produto pode ser enviado ao comprador, tudo com prazos bem definidos. Neste exemplo de instantâneos periódicos, cada registro representa uma ordem de compra, com diversas datas, uma para cada passo do fluxo de processo e, cada vez que alguma coisa ocorre na ordem de compra, o registro é modificado com as novas informações.

Cada um dos modelos de tabelas de fatos apresentados tem suas características próprias e casos que não se adequarem às características destes modelos podem exigir a utilização de modelos híbridos. Por exemplo, em uma estrutura que tem uma perfeita adequação ao modelo de "instantâneos acumulativos", que não provê armazenamento de histórico. Caso o histórico seja uma necessidade na tabela, pode ser utilizado um modelo híbrido com "instantâneos periódicos", permitindo o armazenamento de um novo registro na tabela de fatos quando ocorre um novo 
evento, ao invés de atualizar as colunas do registro correspondente, que seria o esperado no modelo de "instantâneos acumulativos".

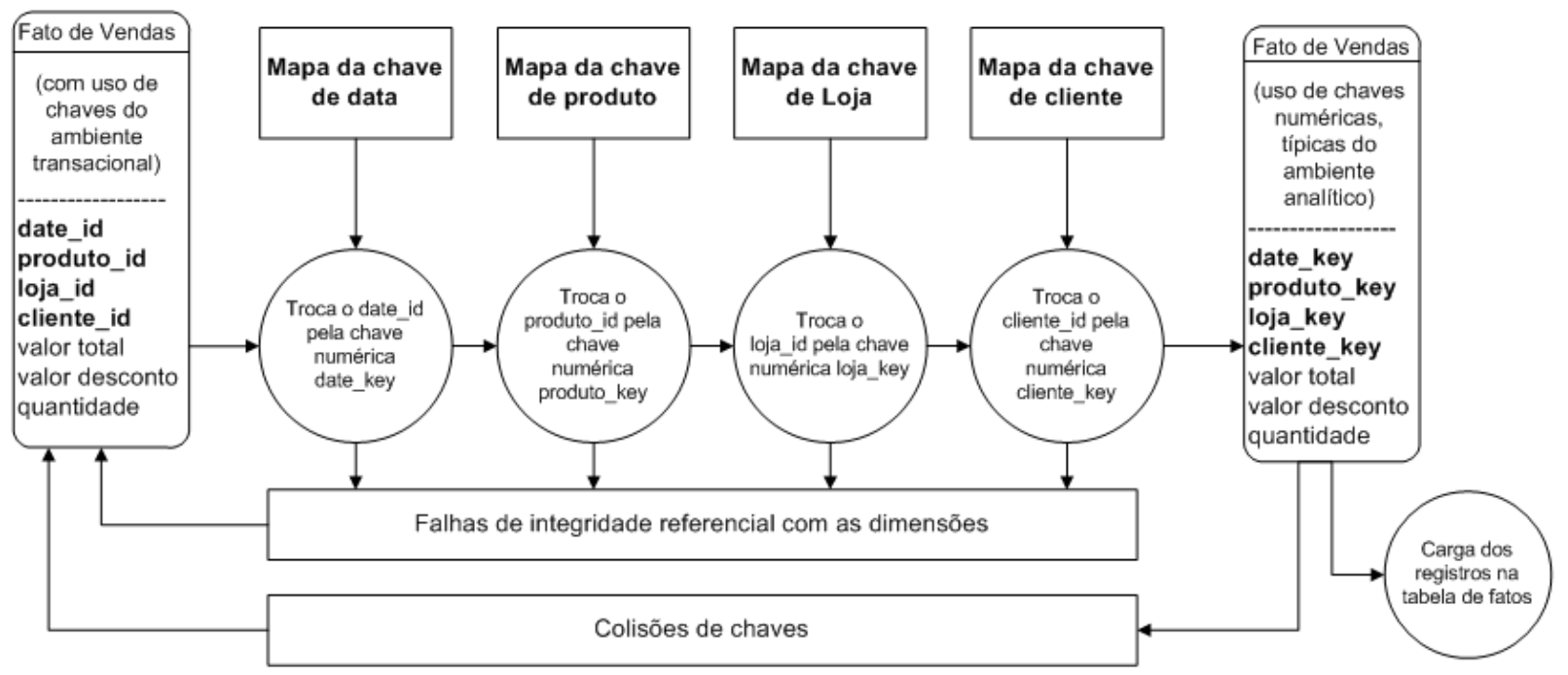

Figura 2.5: Atribuição de chaves numéricas (surrogate keys) no lugar das chaves do ambiente transacional, utilizando tabelas de lookups

Um importante subsistema auxiliar no processo de ETL é o gerenciador de surrogate keys, que tem a responsabilidade de atribuir as chaves numéricas seqüenciais para a carga da tabela de fatos. Para cada chave transacional, o gerenciador define uma chave numérica correspondente na dimensão, que é carregada na tabela de fatos.

A Figura 2.5 mostra também a necessidade de um processo para tratar problemas de integridade referencial e outro processo para verificar se há duplicação de chaves antes de carregar a tabela de fatos no banco de dados e, somente após estas validações, a carga pode ser efetuada.

Além dos sistemas apresentados até aqui, a fase de "entrega de dados para apresentação" tem também outras responsabilidades. Uma delas é o tratamento de dados que chegam com atraso para carga e, neste caso, podem ser de dimensões ou de tabelas de fatos. Nos dois casos, é necessário conhecer os efeitos do atraso e saber como proceder durante a carga sem os dados que faltam e, posteriormente quando os dados chegarem, pois o processamento pode exigir correções em outras tabelas. Por exemplo, como devem ser tratados os registros de uma tabela de fatos de compras, onde o cliente que fez a compra não está na dimensão de clientes e como proceder quando este novo cliente aparecer nos arquivos transacionais e for carregado em sua dimensão.

Além disso, deve haver uma centralização do gerenciamento das dimensões para que a dimensão evolua junto com o DW. Um gerenciador centralizado de tabelas de fatos também é necessário para centralizar quaisquer tipos de intervenções nestas tabelas, desde sua criação ou quaisquer tipos de correções, até a responsabilidade de informar aos usuários seu 
status de atualização.

Uma questão de preocupação para o desempenho no acesso ao DW são as consultas que realizam agregações, que podem consumir muito tempo e recursos do ambiente analítico. Por isso, é comum haver um tratamento diferenciado para esta questão, e uma solução bastante aceita é a utilização de tabelas de fatos pré-agregadas em alguma dimensão de maior utilização, em geral no tempo. Por isso, um construtor de tabelas agregadas é considerado um subsistema do ambiente ETL que tem a função de construir estas tabelas, podendo também identificar os problemas de desempenho que podem ser resolvidos com a aplicação desta solução.

Outro subsistema que trabalha diretamente a favor dos usuários é o construtor de cubos OLAP ${ }^{5}$. Estes cubos permitem uma manipulação dinâmica de relatórios pelos usuários, uma ação popularmente conhecida por slice and dice. O cubo OLAP é uma extensão do DW e deve ser construído após o término da sua carga, que pode ser construído e gerenciado pela própria ferramenta OLAP do projeto. Por fim, um subsistema de propagação de dados pode ser bastante útil, pois há casos em que os dados precisam ser gerados em um formato específico, como sistemas de mineração de dados, ou ainda para o envio de informações para órgãos de controle governamental, que exigem arquivos em um formato padronizado. Para a geração deste tipo propagação dos dados do DW é necessária uma extração e uma formatação com a saída desejada, que é a tarefa deste último subsistema da fase de entrega dos dados para apresentação.

\section{Gerenciamento do ambiente de ETL:}

Após o término das fases anteriores (extração de dados, limpeza e padronização dos dados e entrega dos dados para apresentação), o gerenciamento deste complexo sistema exige cuidados especiais para garantir que características gerenciais e evolutivas não façam o trabalho realizado no desenvolvimento se perder. As três características levantadas por Kimball [38] para um bem sucedido gerenciamento do ambiente são as seguintes:

- Confiabilidade: o processo ETL deve ser capaz de rodar consistentemente até seu fim, provendo os dados em um tempo adequado e com uma boa regularidade.

- Disponibilidade: o DW deve atingir níveis de serviço adequados e acordados com os usuários.

- Gerenciabilidade: um DW de sucesso nunca está pronto. Ele deve evoluir junto com a empresa e, conseqüentemente, o processo de ETL deve seguir o mesmo caminho.

Para que o processo de ETL tenha um bom gerenciamento, atendendo bem a estas três características, o autor descreve nada menos que treze subsistemas gerenciais. Problemas de várias

${ }^{5}$ OLAP é a sigla para On-Line Analytical Processing 
naturezas são tratados nestes subsistemas e o resumo apresentado nos próximos parágrafos contempla os itens mais relevantes ao trabalho.

A primeira discussão é sobre a necessidade de suporte a agendamento de tarefas (ou scheduler de execução de jobs) no ambiente ETL, que deve preferencialmente ter suporte nativo na ferramenta escolhida. Além disso, a ferramenta deve permitir o seqüenciamento de tarefas, facilitando a visualização e a administração das dependências entre os módulos, além permitir notificações automáticas de erros e manter logs de todas as execuções.

Durante suas muitas execuções é normal que, por diversos motivos, a execução do processo ETL seja interrompida, por exemplo por falhas na rede, falhas no banco de dados, falhas de memória ou de disco, problemas na qualidade dos dados, etc. Qualquer destes exemplos podem fazer a execução parar e é aí que surge a necessidade de um sistema de recuperação e reinicialização, cujo principal objetivo é facilitar a reexecução do processamento interrompido, aproveitando ao máximo o bloco já executado, mas priorizando o alto nível de confiança dos dados. A política de backups é também de extrema importância para este sistema de recuperação e reexecução de tarefas, pois há casos de falhas onde pode ser necessário recuperar backups de tabelas modificadas ou corrompidas.

Há ainda outras tarefas administrativas importantes, como a utilização de ferramentas de controle de versão, que garantam uma boa implantação das novas versões do projeto, com boas garantias de qualidade. Também é necessário um bom sistema para controle de fluxo, cuja principal responsabilidade é a contínua monitoração da qualidade e eficiência de todo o fluxo do processamento ETL, possibilitando que contínuas melhorias possam ser realizadas e permitindo identificar e corrigir rapidamente problemas causados por gargalos de desempenho. Além disso, é necessário que qualquer campo possa ser rastreado, ou seja, que sua origem e todas as transformações sobre ele possam ser rapidamente identificadas, bem como dos campos que ele tenha alguma dependência. Uma boa estratégia para isso é utilizar uma ferramenta de ETL com capacidade de rastreamento gráfica, ou utilizar o suporte de documentação automática da própria ferramenta de ETL, para que não sejam necessários excessivos trabalhos da equipe no desenvolvimento de documentações.

Por fim, espera-se que a janela de execução do processo ETL seja sempre respeitada, o que pode representar um desafio em organizações com volumes de dados muito grandes. Por isso, uma eficaz utilização dos recursos disponíveis é fundamental, particularmente de processamento paralelo, que pode reduzir consideravelmente o tempo de execução do ETL e a adição de novos nós de processamento podem dar a escalabilidade necessária ao natural crescimento do volume de dados na empresa. Os últimos sistemas citados por Kimball tratam do gerenciamento da segurança no processo ETL e sobre o gerenciamento do repositório de metadados do DW, que deve incluir os metadados do processo de ETL, que tem uma alta representatividade no conjunto de metadados do DW. 


\section{5 - Trilha das Aplicações de BI}

A trilha de implementação das aplicações de BI é realizada em paralelo às duas outras trilhas descritas anteriormente. Aplicações de BI devem oferecer uma interface de usuário limpa e eficaz [38], sendo amplamente utilizadas em projetos de DW. As ferramentas de BI têm o DW como fonte e sua função é disponibilizar aos usuários uma interface simples para visualização de relatórios, com as seguintes características.

- Dados corretos: todos os relatórios disponibilizados por uma ferramenta de BI devem ser construídos com base em dados confiáveis.

- Desempenho: o tempo de resposta tem que ser curto (atingir uma média de cinco segundos por consulta é uma boa meta).

- Facilidade de uso: usuários que conheçam operações básicas de computação podem extrair relatórios e gráficos da ferramenta com facilidade.

- Boa aparência: as ferramentas de BI devem ter um visual limpo e atraente.

- Investimento de longo prazo: documentações, manutenções e aprimoramentos adequados devem ser sempre realizados nas aplicações de BI.

Segue uma breve descrição das categorias básicas de aplicações de BI, que vão de acessos convencionais ad-hoc por consultas SQL até relatórios pré-definidos e dashboards, capazes de apresentar uma visão global de desempenho dos processos de negócio em uma interface unificada.

1. Acesso direto por consultas ad-hoc: Permitem que os usuários acessem diretamente os dados da base, em consultas criadas por eles mesmos. Este tipo de acesso pode provocar gargalos de desempenho, pois as consultas podem apresentar problemas que comprometam o ambiente e devem ter uma monitoração diferenciada pelo administrador do banco de dados.

2. Mineração de dados: análises estatísticas no DW para criação de modelos que ajudem a identificar padrões e relacionamentos úteis entre as variáveis. Os resultados destas análises são utilizadas posteriormente em outras ferramentas e relatórios, para que as correlações identificadas sejam utilizadas em outros processos.

3. Relatórios pré-definidos: são relatórios previamente modelados, executados e formatados, que permitem aos usuários um pequeno grau de interatividade, mas que podem estar ligados a relatórios analíticos, que oferecem maior flexibilidade. 
4. Relatórios analíticos: permitem uma maior interatividade, geralmente são voltados a algum processo de negócio específico e tornam os relatórios manipuláveis por métodos avançados de análise, como pivoteamento, drill down e drill up, formatações e ordenações avançadas, agregações dinâmicas, cálculos por colunas, cálculos por linhas, gráficos e diagramas, exportação dos resultados para diversos formatos, etc.

5. Dashboards e scorecards: envolvem uma combinação de relatórios e gráficos de diferentes processos de negócios em uma interface centralizada e com uma boa aparência visual. Permitem pouca manipulação, pois seu foco não é flexibilidade analítica, mas sim de oferecer uma visualização limpa e global do desempenho de diversos indicadores corporativos. Um conhecido exemplo de scorecards são os balanced scorecards, ou BSC, desenvolvidos por Kaplan e Norton [31-33], amplamente utilizados no mercado pela sua flexibilidade e por serem aplicáveis a quaisquer empresas ou órgãos que precisem medir seu desempenho em relação aos objetivos traçados, dentro de um plano estratégico corporativo.

6. Relatórios de BI operacional: são relatórios que têm a finalidade de aumentar a produtividade de setores operacionais pela visão global histórica do negócio, disponibilizando aos departamentos operacionais as informações necessárias para este aumento de produtividade. Um exemplo é oferecer a operadores de call center uma ficha do cliente que está ligando, com possíveis ofertas de produtos adequados ao seu perfil de consumo, ou mesmo alguma promoção para reter bons cliente que estejam com comportamento típico de clientes que abandonam a base. Este tipo de informações não é acessível a partir do ambiente transacional e o uso de aplicações de BI sobre o DW é fundamental para o sucesso deste tipo de ações operacionais.

As aplicações de BI têm papel chave no sucesso do DW pois são uma importante ferramenta de acesso e possibilitam que os usuários possam extrair do ambiente analítico as informações que precisam. O desenvolvimento destas aplicações são iniciadas logo após a especificação de requisitos, primeiro com a compreensão dos relatórios mais utilizados pelos usuários e, em seguida, pelo desenho dos primeiros relatórios e aplicações que serão desenvolvidos.

\subsubsection{Projeto de Aplicações de BI}

A trilha das aplicações de BI é uma atividade que, inicialmente, depende de outras, como da escolha e implantação das ferramentas na trilha da tecnologia e das definições de modelagem de dados, na trilha dos dados. No entanto, a fase de projeto das aplicações se inicia com compreensão do ambiente de relatórios da corporação, o que é uma tarefa difícil e que deve ser muito bem executada antes de qualquer implementação.

Após compreender o ambiente, uma segunda necessidade é criar os primeiros modelos de relatórios 
do ambiente analítico, uma atividade fundamental para que o conhecimento adquirido anteriormente seja mantido e disseminado na equipe. Estes modelos iniciais de relatórios devem suprir as necessidades dos usuários e ser acompanhados e aprovados por eles, para minimizar o risco de erros conceituais dentro da equipe e evitar que ocorram erros maiores no futuro.

Os desenvolvedores precisam criar, com ajuda do pessoal de negócios, uma lista dos relatórios que podem ser construídos no DW e que tragam maior valor. Esta listagem de possíveis relatórios deve ser consolidada e priorizada, para posterior implementação. Os relatórios selecionados para implantação devem ser documentados por alguns critérios de especificação de relatórios [37], que são os cinco itens a seguir:

1. Um exemplo físico do relatório que será implementado

2. Lista de todas as possíveis interações dos usuários com o relatório

3. Descrição das origens de cada parte do relatório

4. Algoritmos, cálculos e regras de negócios para o relatório

5. Interações do relatório com sistemas externos

Estes itens devem ser documentados para cada relatório, preferencialmente com suporte da própria ferramenta de BI, enriquecendo o metadados deste ambiente. Finalmente, outras características de projeto, como tipos de acessos, permissões e layouts padrões, também devem ser definidos e uma revisão geral precisa ser feita antes da efetiva implementação pela equipe de desenvolvimento.

\subsubsection{Desenvolvimento da Aplicação de BI}

Com as especificações de relatórios em mãos, as equipes de desenvolvimento podem trabalhar neles, implementando cada um em sua ordem de priorização. Em geral, as ferramentas de BI demandam que relatórios tenham uma definição de domínio pré-estabelecida, pois a pré-definição do domínio possibilita a criação dos cubos OLAP, ou outras técnicas de cache, nos relatórios.

Portanto, são definidos os domínios de cada relatório e as equipes podem trabalhar no desenvolvimento deles, de acordo com as especificações de cada um. Um relatório padrão, muito comum no ambiente analítico, exige um bom trabalho de implementação e validação, além de diversas adequações que devem ser feitas para que sua apresentação visual esteja adequada.

Após a implementação e validação de cada relatório, há tarefas gerenciais que também precisam ser efetuadas, como como dar os acessos corretos aos usuários, migração do relatório para o ambiente de homologação / produção, etc. Também pode ser necessário realizar agendamento de execução e 
envio dos relatórios para que, após a carga do DW, os relatórios sejam atualizados e enviados aos seus destinatários, ou disponibilizados em suas interfaces de acesso pois, como a carga do DW é geralmente feita de madrugada, os relatórios poderão estar prontos já pela manhã e os colaboradores poderão utilizá-los logo que chegarem à empresa.

\subsection{Integração e Implantação}

A fase de integração é a fase onde todos os sistemas desenvolvidos na iteração são colocados no mesmo ambiente para a execução de testes globais. A principal característica desta fase de integração é a bateria de testes que é executada sobre os sistemas, que deve ter uma massa de dados adequada para que as validações reflitam ao máximo o ambiente de produção. Os testes de integração são uma valiosa ferramenta de validação para todo o ciclo de desenvolvimento e a identificação de quaisquer problemas nesta etapa têm um custo muito menor à equipe e a toda a empresa do que uma descoberta posterior do erro, principalmente se os prejuízos forem significativos à empresa.

Por estas razões, os testes de integração são fundamentais à passagem dos novos desenvolvimentos em produção e todo o conjunto de testes deve ser executado para isso. A cada iteração, novos testes devem ser desenvolvidos, mas todos, inclusive os das iterações anteriores, devem ser executados. As principais características a serem validadas nos testes são:

- Procedimento de testes: a metodologia de testes de integração que será utilizada deve ser definida, de forma que não deixe dúvidas a usuários e a auditores que o ambiente está sendo suficientemente testado. Qualquer metodologia adotada deve ser composta por pelo menos quatro categorias: definição dos testes a serem executados, definição de um conjunto de dados inicial para testes, definição de um conjunto de dados para teste de exceções e executar todos os testes, armazenando os logs.

- Testes de qualidade de dados: validação da qualidade dos dados históricos e incrementais.

- Testes das operações do processo: valida se cada processo está sendo executado corretamente e se tudo está sincronizado e funcionando em conjunto.

- Testes de desempenho: para garantir que tanto o processo de carga quanto o tempo de resposta das aplicações de BI tenham um desempenho aceitável.

- Testes de implantação: validações dos scripts de migração entre os ambientes.

- Teste de acessibilidade de usuários: testes para garantir que o ambiente de trabalho dos usuários têm as tecnologias necessárias para utilizar todas as funcionalidades. 
A primeira implantação é simples mas, depois que o sistema entra em produção, realizar uma implantação passa a ser uma tarefa bem mais complicada. Deve-se pensar em toda a infra-estrutura que precisa ser migrada e os mesmos scripts que realizaram a migração do ambiente de desenvolvimento para o ambiente de homologação têm que ser utilizados para passagem a produção, evitando possíveis problemas de migração.

\subsection{Manutenção}

A manutenção do DW não é uma tarefa de alta complexidade, mas exige atenção constante, além de uma adequada monitoração das atividades de back room e de front room. Além disso, esta manutenção demanda constante suporte aos usuários do ambiente e o Help Desk da empresa geralmente não tem qualificação para dar suporte a problemas no DW. Ele pode ajudar em problemas de conectividade ou de acesso, mas não pode tratar de questões relacionadas ao negócio ou à arquitetura.

Uma estrutura de suporte por camadas é a forma adequada [38] para oferecer um suporte de qualidade aos usuários, com uma estrutura de 3 níveis:

1. Nível 1: é o suporte mais básico, composto principalmente por documentações do portal de BI e pelo Help Desk da empresa, responsável por direcionar questões ao suporte de 2o nível.

2. Nível 2: resolve questões como solicitar o desenvolvimento de novos relatórios ou de utilizar alguma funcionalidade já existente.

3. Nível 3: envolvimento da equipe de front-room para dar suporte aos usuários. Novos desenvolvimentos, correções de erros e sugestões de melhorias são algumas das tarefas que devem chegar a este nível.

Além do suporte, a etapa de manutenção do DW exige um bom gerenciamento e muita monito-

ração. É preciso garantir a segurança dos dados e do ambiente, além de monitorar o uso, para saber quem está utilizando o que. Além disso, os recursos também precisam ser monitorados no back-room, pois o processamento ETL, além de executado, precisa ter um ambiente de execução sempre adequado e, por isso, deve estar sempre em observação. Por fim, a política de backup do ambiente também precisa estar bem definida.

\subsection{Crescimento}

Após a entrada em produção e a montagem da estrutura de manutenção e suporte, a expansão do DW é o primeiro grande desafio que o gerente do projeto enfrenta. É natural que a versão que acaba de entrar em produção contemple bem alguma área, que logo pedirá novos relatórios, enquanto 
outras áreas são menos atendidas e solicitam novos desenvolvimentos. Esta situação é normal em um DW bem sucedido e os responsáveis pelo projeto devem ponderar e selecionar os desenvolvimentos de melhor custo/benefício a serem feitos, de forma que o suporte e as tarefas administrativas do ambiente em produção não sejam prejudicadas.

Antes de iniciar uma nova fase de desenvolvimento, o responsável pelo projeto deve analisar criteriosamente a evolução da equipe em relação às fases de desenvolvimento anteriores. Para isso, ao final de cada fase, realizar medidas de eficiência é uma atividade fundamental. Por exemplo, medir o tempo que foi planejado e o tempo real, medir o "retorno sobre o investimento" planejado e o real, medir a eficiência da equipe e a satisfação dos desenvolvedores com o projeto. Todas estas medições podem ajudar muito na próxima etapa de desenvolvimento, pois elas permitem quantificar fatores que podem ser melhorados.

A continuidade do DW é feita com a reaplicação do método apresentado neste capítulo, conforme descrito na Figura 2.1, e é necessário passar novamente por todas as fases do ciclo para que novos desenvolvimentos entrem em produção. O novo ciclo pode levar poucos dias, quando por exemplo todas as fontes já estiverem no processo de ETL, ou alguns meses, quando os desenvolvimentos exigirem que fontes complexas e desconhecidas ao ambiente analítico sejam acrescentadas. Em qualquer dos casos, todas as etapas do projeto devem ser novamente executadas.

\subsection{Gerenciamento do Projeto}

O Gerenciamento do projeto está relacionado a todos os itens descritos no processo de engenharia de DW pois, como detalhado anteriormente, exige um forte controle de acompanhamento, monitoração, manutenção, suporte a usuários e identificação de sinais que possam se tornar problemas futuros.

Dentre as atividades de gerenciamento durante o desenvolvimento do projeto estão a condução das reuniões de equipes, o sincronismo entre todas as frentes de desenvolvimento e monitoração das atividades com freqüente acompanhamento do cronograma geral. Tudo isso deve ser consolidado periodicamente em um relatório de status de projeto, pois a documentação centralizada é também uma responsabilidade do gerenciamento, bem como a contínua busca pela manutenção do cronograma, com adaptação a situações que possam surgir ao longo do processo (como alterações de escopo por exemplo).

Neste contexto, um ciclo de desenvolvimento pode ser considerado como um projeto e, de fato, Kimball [35] utiliza exatamente esta nomenclatura (e não ciclo de desenvolvimento). Para ele, no desenvolvimento de um projeto, a equipe trabalha sempre em um data mart específico, que é um

subconjunto departamental do DW. Por isso, cada "projeto" (ou ciclo de desenvolvimento) tende a se isolar, pois cada departamento visa atender somente suas próprias necessidades, sem se preocupar 
com o que já existe em outros departamentos.

De maneira corporativa, um bom gerenciamento do projeto global de DW é fundamental para que haja uma visão ampla do que cada "projeto" representa dentro do DW. Deve haver uma responsabilidade corporativa pela contínua adequação e aperfeiçoamento do DW, priorizando sempre o bem maior para a empresa, mesmo que isso leve algum departamento a ter algum prejuízo em relação a outros (como por exemplo abrir mão de algumas nomenclaturas de variáveis para que todos os departamentos enxerguem a mesma informação da mesma forma).

Para que o DW represente a empresa, é muito importante seguir por este caminho de padronização de conceitos, elevando a administração dos dados ao nível corporativo e garantindo que os processos e as regras de negócio estejam centralizados, para posterior distribuição da informação nos data marts. Isso garante que, qualquer indicador do DW, não importa quão complicada seja sua regra de negócio, será visto da mesma forma por todos os departamentos, garantindo que o DW tem uma visão única do negócio da empresa.

\subsection{Resumo do Capítulo}

Este capítulo se iniciou com a descrição do contexto em que se encontra um DW, em uma análise histórica das soluções desenvolvidas por empresas e pesquisadores para o problema que surgia na década de 70: ter um ambiente analítico sem degradar a estrutura e o desempenho do ambiente transacional. As principais propostas foram apresentadas e, após um breve comparativo, o método de Kimball foi escolhido como o método tradicional mais adequado aos propósitos deste trabalho, definido então como a principal referência a ser seguida.

Todos os passos do método tradicional apresentado na Figura 2.1 foram descritos de maneira resumida e, apesar de a referência principal do capítulo ter sido Kimball, diversas outras fontes foram citadas ao longo do texto na comparação de conceitos conflitantes ou comuns, relacionadas ao processo de engenharia de DW descrito. 


\section{Capítulo 3}

\section{Métodos de Evolução em Bancos de Dados}

Mudanças fazem parte do processo evolutivo de todas as empresas e, com elas, surgem novos requisitos que demandam constantes alterações em seus sistemas e em seus bancos de dados. Quando não há alteração da semântica comportamental de um sistema, a alteração é conhecida como refatoração. Martin Fowler [20] descreve esta técnica que, segundo ele, é uma disciplina que tem por objetivo melhorar a estrutura interna do sistema, aprimorando qualidade e desempenho, sem alterar seu comportamento externo. Ao tratar um processo de evolução de bancos de dados, o conceito de refatoração também se aplica, mas a definição é um pouco diferente em relação a esta definição de Fowler.

Esta diferença existe porque, apesar de os objetos que compõem um banco de dados também estarem sujeitos a alterações, ao refatorar um banco não basta alterar sua estrutura, pois os dados armazenados nele também devem ser tratados, e é aí que está a maior complexidade para aplicar refatorações em bancos, pois os dados são um atributo dinâmico no sistema e se tornam parte do processo de evolução do ambiente. A definição de refatoração para bancos de dados é tratada em detalhes neste capítulo, que também cita algumas das particularidades relacionadas à aplicação de refatorações no modelo dimensional.

\subsection{O Conceito de Bancos Evolutivos}

No processo de bancos evolutivos descrito por Ambler [54], a refatoração é a principal técnica dentro de um conjunto de outras técnicas (que envolvem desde modelagem evolutiva até a montagem dos ambientes de trabalho dos desenvolvedores), e que compõem uma abordagem mais completa no desenvolvimento de bancos evolutivos. As técnicas desta abordagem são:

- Refatoração de banco: permite a evolução gradual de um esquema de dados, aprimorando o projeto do esquema sem alterar sua semântica. 
- Modelagem de dados evolutiva: permite que o modelo de dados evolua gradual e iterativamente, acompanhando sistemas que utilizem o banco.

- Testes de regressão no banco de dados: testes que garantem que o esquema do banco de dados funciona como deve.

- Gerenciamento de configuração de artefatos no banco: os modelos, os dados de teste e os bancos de testes são importantes "artefatos" que devem ser corretamente gerenciados, como parte integrante do projeto.

- Ambientes de desenvolvimento: os desenvolvedores precisam de ambientes de trabalho locais, para que possam modificar, testar e executar o sistema antes que suas versões sejam integradas em um ambiente comum, para que somente então a versão integrada seja passada para produção.

Outro conceito importante relacionado à evolução de um banco de dados é o nível de acoplamento entre objetos, que quantifica a dependência entre estes objetos. Quanto maior for o grau de acoplamento entre dois objetos, maior é a chance de que alterações em um deles demande alterações no outro. A implementação de uma refatoração de banco pode se tornar muito complicada dependendo do nível de acoplamento do banco. Para uma melhor visualização, a Figura 3.1 mostra dois ambientes diferentes: o da Figura 3.1(A), onde o nível de acoplamento é baixo pois há somente um sistema que interage com o banco, e o da Figura 3.1(B), onde o nível de acoplamento é alto, pois há diversos sistemas interagindo com o banco de dados.

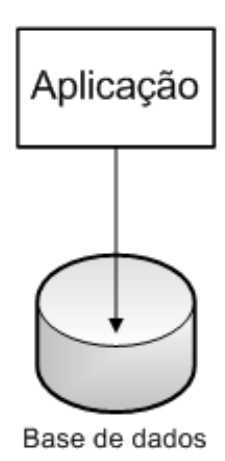

(A)

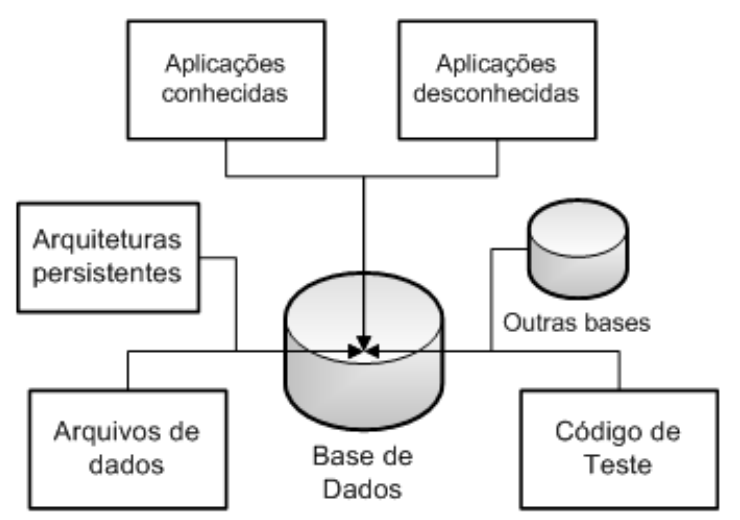

(B)

Figura 3.1: Exemplos de níveis de acoplamento baixo em (A) e alto em (B)

No primeiro caso é possível realizar uma alteração no banco e no sistema simultaneamente e implantar a nova versão ao mesmo tempo. Já no segundo caso isso não é possível, pois há vários sistemas que utilizam o banco de dados, o que dificulta uma alteração simultânea em todos os sistemas 
envolvidos. Neste caso, é necessário um período de transição, onde os dois esquemas do banco (o antigo e o novo) funcionam em paralelo, dando algum tempo para todos os sistemas se adequarem ao novo esquema, para somente então desativar o esquema antigo.

O DW tem um nível de acoplamento naturalmente mais baixo que bancos de dados transacionais. A primeira justificativa para esta afirmação é que o DW utiliza fortemente o modelo dimensional, apresentado na Seção 2.4.1, que torna as consultas de acesso mais previsíveis em relação a um modelo normalizado. Além disso, as aplicações de acesso utilizadas pelos usuários têm o objetivo principal de leitura, seja pela extração de relatórios ou por outras aplicações equivalentes, normalmente em consultas que realizam agregações. No Capítulo 4, um exemplo de DW evolutivo vai mostrar como esta característica favorece seu crescimento sem grandes alterações nas aplicações que o acessam.

\subsection{Refatoração de Banco de Dados}

Como uma extensão do conceito de refatoração de sistemas, Ambler e Sadalage [54] definem refatoração de banco de dados da seguinte forma:

Uma refatoração de banco de dados pode ser definida como a realização de uma alteração simples no esquema do banco, com o objetivo de otimizar o projeto, mas preservando sua semântica informacional e sua semântica comportamental.

A semântica informacional está relacionada com a visão externa ao banco, ou seja, como os usuários enxergam as informações do ponto de vista de negócios. Neste caso, uma informação que existia antes da refatoração deve continuar existindo após a refatoração. Um exemplo é a padronização de nomes de ruas em uma tabela de endereços, onde dados como "R. Brasil", "Rua Brasil" assumem um padrão comum passam a se chamar "Rua Brasil", ou seja, a informação continua existindo, mesmo com a alteração dos dados de alguns registros nesta coluna.

A semântica comportamental está relacionada com a manutenção das funcionalidades existentes antes da alteração ser efetuada. Desta forma, programas que utilizavam o banco de dados antes da refatoração devem ter seus códigos atualizados para que continuem funcionando após a refatoração. Um exemplo simples é a aplicação de uma alteração no nome de uma tabela de "Address" para "Endereco", onde todos os programas que utilizavam o nome da tabela antigo devem passar a utilizar o novo nome.

No trabalho de Fowler há mais de sessenta tipos de refatorações, divididas em seis categorias: estrutural, qualidade, integridade referencial, arquitetura, método e transformação. É interessante notar que uma refatoração de banco de dados é conceitualmente mais difícil que uma refatoração de código pois a refatoração de código deve conservar apenas a semântica comportamental, 
enquanto a refatoração de banco de dados deve se preocupar também com a semântica informacional.

Uma observação importante é que uma refatoração de banco de dados é, segundo esta definição, um conceito restrito pois uma grande alteração ou uma extensão do esquema não são considerados refatorações (por exemplo a adição de uma nova tabela ou de uma nova coluna). Para este tipo de modificações no esquema, a nomenclatura utilizada pelos autores é transformação.

O conceito de refatoração de banco de dados pode ser categorizado de acordo com o objetivo da refatoração. Ambler [54] distribui os mais de sessenta tipos de refatorações em seis categorias e a Tabela 3.1 traz a descrição de cada uma delas, incluindo a de transformações, que no trabalho original não é considerado como refatoração.

Tabela 3.1: Categorias de refatorações de banco

\begin{tabular}{|l|l|l|}
\hline Categoria & Descrição & Exemplos \\
\hline Estrutural & $\begin{array}{l}\text { Uma mudança na definição de uma } \\
\text { ou mais tabelas ou visões. }\end{array}$ & $\begin{array}{l}\text { Mover uma coluna de uma tabela para outra } \\
\text { ou dividir uma coluna em várias. }\end{array}$ \\
\hline $\begin{array}{l}\text { Qualidade de } \\
\text { dados }\end{array}$ & $\begin{array}{l}\text { Uma mudança que melhora a qua- } \\
\text { lidade da informação contida no } \\
\text { banco de dados. }\end{array}$ & $\begin{array}{l}\text { Alterar a definição de uma coluna de modo a } \\
\text { não permitir valores nulos. }\end{array}$ \\
\hline $\begin{array}{l}\text { Integridade } \\
\text { referencial }\end{array}$ & $\begin{array}{l}\text { Uma mudança que garante que o } \\
\text { registro referenciado existe em uma } \\
\text { outra tabela, ou que, se desneces- } \\
\text { sário, o registro possa ser removido } \\
\text { corretamente. }\end{array}$ & $\begin{array}{l}\text { Adicionar uma trigger para apagar registros } \\
\text { em cascata, entre duas entidades. }\end{array}$ \\
\hline Arquitetural & $\begin{array}{l}\text { Uma mudança que melhora global- } \\
\text { mente a maneira como programas } \\
\text { externos interagem com o banco de } \\
\text { dados. }\end{array}$ & $\begin{array}{l}\text { Substituir uma operação Java existente em } \\
\text { uma biblioteca de código compartilhado por } \\
\text { uma stored procedure no banco de dados, per- } \\
\text { mitindo disponibilizar a operação para aplica- } \\
\text { ções escritas em outras linguagens. }\end{array}$ \\
\hline Método & $\begin{array}{l}\text { Uma mudança em um método } \\
\text { (uma stored procedure ou trigger }) \\
\text { que melhora sua qualidade. Mui- } \\
\text { tas das refatorações de código são } \\
\text { aplicáveis. }\end{array}$ & $\begin{array}{l}\text { Renomear uma stored procedure para tornar } \\
\text { mais fácil sua compreensão. }\end{array}$ \\
\hline Transformação \\
$\begin{array}{l}\text { Uma mudança no esquema do } \\
\text { banco de dados que altera sua se- } \\
\text { mântica informacional. }\end{array}$ & $\begin{array}{l}\text { Adicionar uma nova coluna em uma tabela } \\
\text { existente. }\end{array}$ \\
\hline
\end{tabular}




\subsection{Aplicando as Refatorações}

Ambler [54] propõe um ambiente de desenvolvimento completo onde, tanto a aplicação quanto o banco de dados estão presentes, permitindo desenvolvimentos e testes de unidades para cada nova modificação. Cada equipe do projeto precisa de ambientes de desenvolvimento individuais e também de ambientes comuns para integração das modificações e homologação do ambiente integrado. Com esta estrutura, possíveis erros impactam apenas o trabalho de cada equipe e o risco global é reduzido.

Ao se deparar com uma necessidade de refatoração de banco (seja causada por um novo requisito ou para correção/evolução da aplicação), o administrador de banco de dados e o desenvolvedor devem seguir uma série de passos para desenvolver a refatoração, garantindo sua integridade e corretude. A Figura 3.2 mostra o processo de refatoração de banco que deve ser realizado iterativamente. A seguir cada uma das etapas do diagrama são descritas.

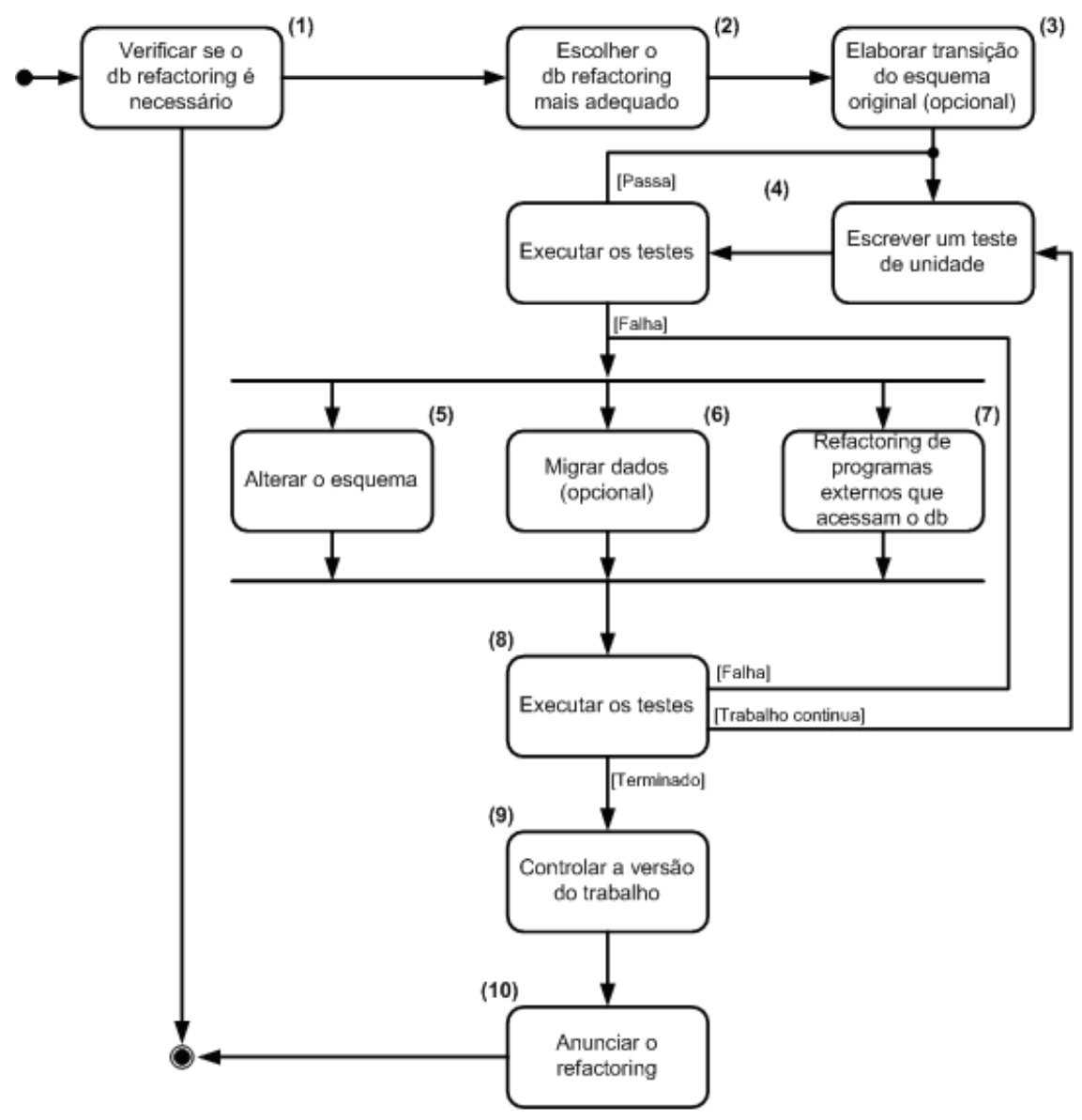

Figura 3.2: Diagrama do processo de Refatoração de Banco [54]

\section{Verificar se a refatoração é necessária}


Nesta etapa, deve-se considerar se realmente faz sentido a alteração, se há alguma necessidade de negócio beneficiada por ela e se o esforço de implementar a alteração justifica a mudança. É importante realizar uma avaliação do nível de acoplamento dos artefatos de banco envolvidos.

\section{Escolher a refatoração de banco mais adequada}

Uma vez que é possível aplicar um grande número de refatorações, deve-se avaliar qual a

refatoração mais adequada para cada caso. É necessário ter cuidado na escolha da solução para o problema pois, além de uma correta identificação, deve-se garantir, antes de qualquer implementação, que a nova funcionalidade já não exista em alguma outra parte do sistema.

\section{Elaborar a transição do esquema original do banco de dados}

Este item é opcional e se aplica aos casos em que múltiplas aplicações acessam o banco, aumentando a complexidade da transição do esquema antigo para o novo. Neste caso, pode não ser possível alterar o banco e implementar as alterações em todos os programas simultaneamente.

Neste caso, pode ser necessário um período de transição para o esquema que está sendo alterado, durante o qual deve existir possibilidade de uso do esquema original e também do novo esquema em paralelo, para que os desenvolvedores tenham tempo para implementar as alterações nas outras aplicações que acessam o banco de dados.

Para Ambler [2], durante esse período de transição é necessário assumir que algumas aplicações utilizarão o esquema original, enquanto outras farão uso do novo esquema. Além disso, uma aplicação apenas pode utilizar uma das versões do esquema e não ambas simultaneamente.

Nem todas as refatorações de banco de dados exigem períodos de transição e, no contexto específico do DW, a necessidade deste período é ainda menor, e deve ser evitado sempre que possível pois dois bancos de dados funcionando em paralelo causam uma situação muito complexa ao ambiente analítico. Esta situação é pouco comum em um DW pois o acesso feito pelos usuários no banco é bastante previsível, composto basicamente por leitura através de consultas analíticas que realizam agregações sobre os dados, como é mostrado no Capítulo 4.

\section{Testes}

Um conjunto de testes deve ser elaborado e executado até que a refatoração de banco seja completamente implementada. O esquema deve ser testado em todos os aspectos relacionados à alteração, como stored procedures, triggers, regras de integridade referencial, definições de visões, valores default e regras de domínio. Finalmente, devem ser testados também os programas externos que tenham acesso ao banco de dados e que tenham sido alterados.

\section{Alterar o esquema do banco de dados}

Nesta etapa é necessário criar scripts para implementar cada refatoração de banco.

\section{Migrar dados}

Muitas das refatorações de dados requerem algum tipo de tratamento nos dados já armazenados 
no banco. Em alguns casos é necessário mover dados de um local para outro e, no caso de refatorações que envolvem qualidade de dados, é necessário eliminar inconsistências nos valores.

\section{Refatoração de programas externos que acessam o banco de dados}

Alterações no esquema do banco de dados podem exigir alterações nos programas que acessam a parte alterada do esquema. Os métodos para alteração destes programas estão além do escopo deste trabalho, mas há diversas referências sobre o assunto no trabalho de Ambler [54] que também cita algumas opções para esta tarefa.

\section{Testes}

Esta etapa de testes deve ocorrer de maneira análoga ao item de testes descrito anteriormente.

\section{Controlar a versão do trabalho}

Após concluído o desenvolvimento de uma refatoração, é importante que haja um eficiente controle de versões dos artefatos envolvidos, como scripts, geração e dados de teste, casos de teste, documentação, modelos, etc.

\section{Anunciar a refatoração de banco}

Todas as equipes que utilizam o banco precisam ser comunicadas sobre o término da refatoração realizada.

\subsection{Implantando em Produção}

Uma vez que as alterações estejam terminadas (desenvolvidas e testadas), é importante que a implantação em produção seja feita por um processo rigoroso, e a seguinte estratégia é sugerida por Ambler [3, 54]:

\section{- Implantação dos vários ambientes isolados e controlados}

Um ambiente de pré-produção pode ser o local de integração dos bancos de desenvolvimento das equipes (cujas modificações de cada desenvolvedor já devem estar integradas). Este ambiente pode ser utilizado também para homologação dos usuários.

\section{- Aplicação de pacotes de refatoração de banco de dados}

De acordo com a forma de trabalho de cada equipe de desenvolvimento, as alterações podem ser implementadas em curtos períodos de tempo e é recomendável que implantações no ambiente de produção sejam feitas em grupos e em períodos curtos, por tratar-se de uma implantação que demanda maiores cuidados do que integrações locais ou em pré-produção.

\section{- Programar janelas de implantação}

Uma janela de implantação é um período específico onde permite-se implantar um sistema em 
produção. Estas janelas tipicamente coincidem com horários de menor atividade no sistema e ajudam os usuários a saber quando as implantações são feitas.

\section{- Implantar o sistema}

Apesar das situações de baixo acoplamento, deve ser considerada a outra possibilidade, em que vários sistemas interagem com o banco de dados, em um ambiente de alto acoplamento. A implantação em produção deve ser uma ação controlada e sistemática e, conforme mostrado na Figura 3.3, existe uma seqüência de etapas a serem seguidas para a implantação de uma refatoração de banco em produção.

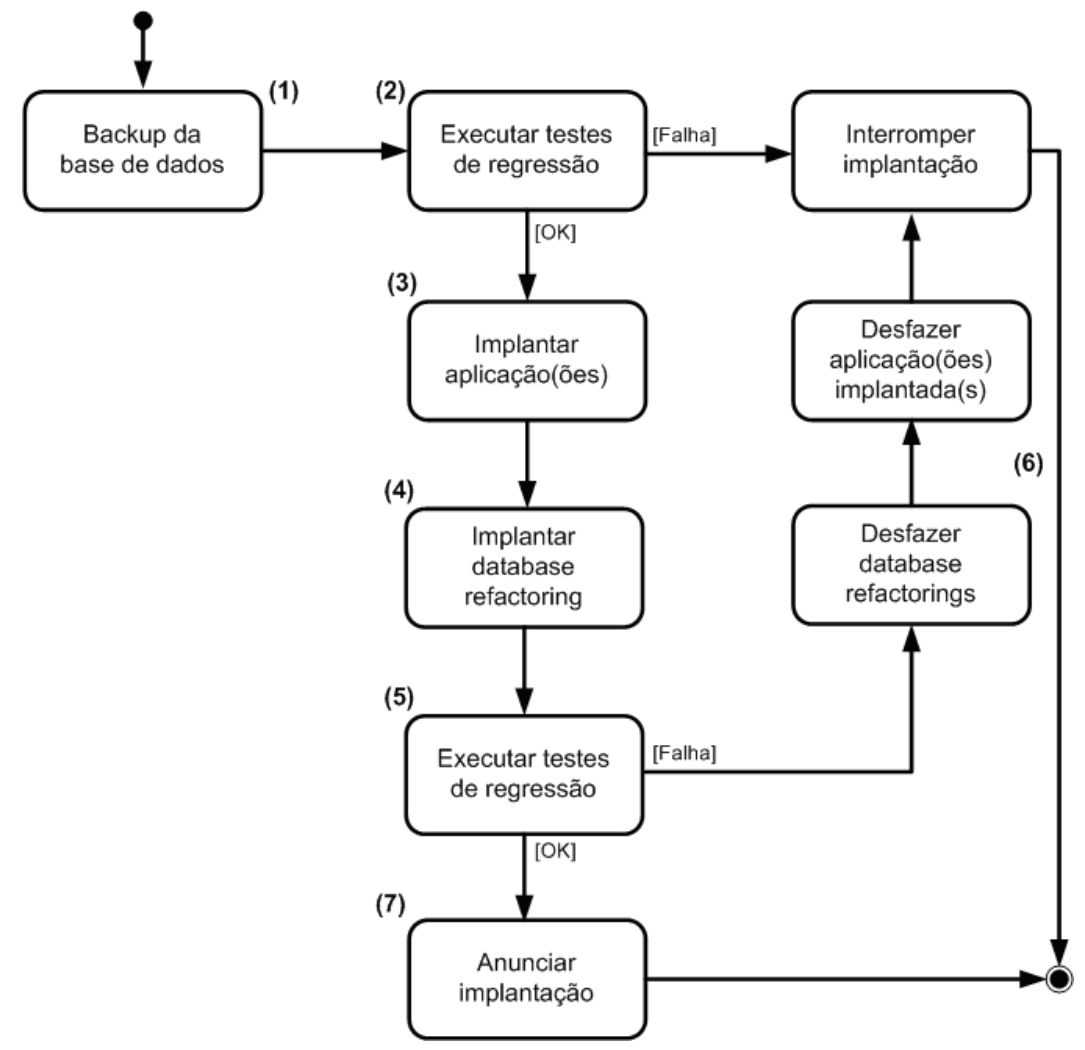

Figura 3.3: Implantação em produção após realizar refatoração no banco

\section{Backup do banco de dados}

Fundamental para que seja possível desfazer a implantação caso ocorra algum problema.

\section{Executar testes de regressão}

Para garantir a corretude do sistema após a conclusão dos testes em pré-produção, evitando também que não ocorra nenhum efeito colateral no ambiente de produção.

\section{Implantação das aplicações externas}

Toda organização tem suas regras de procedimentos para implantação de alterações em ambiente de produção e estas regras devem ser seguidas. 


\section{Implantar as refatorações de banco}

Os procedimentos que alteram o esquema ou fazem migração de dados devem ser aplicados.

\section{Executar testes de regressão}

Após a implantação das refatorações de banco, é preciso verificar se o sistema está funcionando corretamente no ambiente de produção.

\section{Se necessário, desfazer alterações}

Caso ocorra algum erro grave no ambiente de produção, é necessário desfazer as alterações efetuadas utilizando o backup realizado no início do procedimento.

\section{Anunciar os resultados da implantação}

Para transparência do processo, os usuários devem ser comunicados do sucesso (ou não) da implantação realizada.

\section{- Remover o esquema de transição}

Nos casos em que um esquema de transição tenha sido utilizado, o processo de implantação somente é concluído quando ele for desativado. Isto pode levar algum tempo, de acordo com o número de sistemas que utilizam o banco e seu nível de acoplamento. Além disso, a remoção do esquema de transição deve ser um processo bastante controlado e testado, para evitar que ocorram problemas nos sistemas que o utilizavam.

\subsection{Classificação das Evoluções de um DW}

Nesta seção são listadas algumas das refatorações de banco de dados descritas por Ambler [54], de acordo com a categorização feita na Tabela 3.1. Vale ressaltar que o objetivo do trabalho não é de fazer uma descrição completa de todas as refatorações, mas de escolher as mais relevantes ao escopo de um DW evolutivo, e a Tabela 3.2 lista das que melhor se aplicam neste contexto:

Vale lembrar que o item "transformação" da Tabela 3.1 é visto pelos seus autores como um tipo de alteração diferenciada, que não é uma refatoração, mas uma alteração maior no esquema do banco. Uma descrição detalhada de algumas refatorações e transformações pode ser encontrada no Apêndice A deste trabalho, e a Tabela 3.2 traz um conjunto de alterações encontradas com freqüência na evolução do DW, tanto na adição de novas funcionalidades quanto em modificações das existentes. No Capítulo 4, estas refatorações dão suporte na catalogação das possíveis evoluções que o modelo dimensional pode sofrer e também é utilizado no Capítulo 5, no exemplo de aplicação. 
Tabela 3.2: Categorias de refatorações de banco de dados

\begin{tabular}{|l|l|}
\hline Categoria & Refatorações \\
\hline Estrutura & - Adicionar Coluna \\
& - Remover Coluna \\
& - Adicionar Tabela \\
& - Remover Tabela \\
& - Adicionar Visão \\
& - Remover Visão \\
& - Renomear Coluna \\
& - Renomear Tabela \\
& - Renomear Visão \\
\hline Qualidade de Dados & - Criar Tabela de Lookup \\
& - Remover Restrição de Coluna \\
& - Remover Valor Default \\
& - Remover Restrição de Não-Nulo \\
& - Adicionar Restrição de Coluna \\
& - Adicionar Valor Default \\
& - Adicionar Restrição de Não-Nulo \\
\hline Integridade Referencial & - Adicionar Restrição de Chave Estrangeira \\
& - Remover Restrição de chave Estrangeira \\
\hline Arquitetura & - Adicionar Código \\
& - Remover Código \\
\hline & - Adicionar Índice \\
& - Remover Índice \\
\hline
\end{tabular}

\subsection{Resumo do Capítulo}

Inicialmente foi introduzido o conceito de refatoração de sistemas segundo Fowler e de como a aplicação deste mesmo conceito poderia ser adaptado a banco de dados. Foi apresentado então o conceito de bancos evolutivos e o papel central que a refatoração de banco desempenha neste conceito. As seções seguintes aprofundaram a discussão, com definições importantes à sua compreensão, como a semântica informacional e a semântica comportamental, além de questões práticas de aplicação e implantação.

A descrição do processo de aplicação de refatorações em bancos de dados seguiu a seqüência descrita no diagrama da Figura 3.2, com dez passos para uma aplicação segura. Também foi apresentado um procedimento para implantação em produção, em um método bastante seguro sugerido por Ambler. Por fim, uma lista das refatorações e transformações mais prováveis em um DW evolutivo foi feita na Tabela 3.2 . 


\section{Capítulo 4}

\section{Aplicação de Práticas Ágeis em Projetos Evolutivos de DW}

A complexidade de um projeto de DW, como descrito no Capítulo 2, causa uma considerável demora na entrega de funcionalidades aos usuários finais do ambiente analítico. É comum que este tipo de projeto seja bastante burocrático, com documentações extensas e iterações de desenvolvimento grandes e demoradas. O Capítulo 2 define em detalhes o método de engenharia proposto por Kimball [38], que busca construir, de forma iterativa, diversos data marts, que devem ser gradualmente integrados para construção do DW, em uma visão única da empresa.

O método de Kimball abrange todas as necessidades de um DW, é funcional e bastante utilizado no mercado mas, apesar de ser um processo iterativo, não é uma proposta ágil. Esta afirmação é justificada porque o escopo de um data mart pode ser muito grande e, neste caso, o método vai exigir todo o conjunto de burocracias de um grande projeto de software. Essa é a limitação da proposta do Kimball pois, para ele, o data mart deve ser inteiramente desenvolvido, antes que um novo ciclo se inicie.

\subsection{Métodos Ágeis}

Desde a década de 1950 a importância do software vem aumentando cada vez mais. O seu surgimento fez valer a "lei das conseqüências não pretendidas", onde o surgimento de uma nova tecnologia tem influências profundas em diversas outras áreas da ciência [45]. Com seu crescimento, o desenvolvimento do software passou a ser uma atividade própria de engenharia, chamada "Engenharia de Software", que tem duas conhecidas definições formais:

Engenharia de software é a criação e utilização de sólidos princípios de engenharia a fim de obter softwares econômicos, que sejam confiáveis e que trabalhem eficientemente em máquinas reais.

- Fritz Bauer [42] 


\title{
44CAPÍTULO 4. APLICAÇÃO DE PRÁTICAS ÁGEIS EM PROJETOS EVOLUTIVOS DE DW
}

\author{
Engenharia de software é (1) Aplicação de uma abordagem sistemática, disciplinada \\ e quantificada para o desenvolvimento, operação e manutenção do software, isto é, a \\ aplicação da engenharia ao software e; (2) O estudo de abordagens como em (1). \\ - IEEE $[25]$
}

Um modelo de processo é uma abstração de como deve ser o desenvolvimento do software em suas diversas etapas. Ele proporciona informações parciais sobre o processo [50] mas, ao mesmo tempo, oferece uma estrutura útil que pode ser utilizada para colocar ordem no caos do desenvolvimento de software [45]. Para uma melhor compreensão histórica da engenharia de software, é importante citar alguns dos principais modelos de desenvolvimento, pois os métodos ágeis surgem como uma opção evolutiva a estes modelos tradicionais. O objetivo não é detalhar cada modelo de processo e, para maiores informações sobre cada um, a referência pode ser consultada.

O Modelo em Cascata [41,50], também conhecido por "ciclo de vida clássico" é intuitivo e de fácil gerenciamento, mas apresenta diversos problemas decorrentes de sua estrutura, que propõe um desenvolvimento em fases seqüenciais. O Modelo Incremental [50] é parecido com o modelo em cascata, mas é iterativo e entrega funcionalidades parciais aos usuários, a cada iteração. O Modelo RAD [45], ou Rapid Appplication Development, é um modelo incremental cuja implementação é baseada em componentes, com desenvolvimento por equipes paralelas em blocos modularizados do software. A Prototipagem $[12,45]$ mostra os passos a serem seguidos para a criação de um protótipo anterior ao desenvolvimento da aplicação e muitos autores a vêem apenas como uma técnica a ser utilizada por qualquer modelo de processo. O Modelo Espiral $[11,45,50]$ tem uma natureza iterativa e cíclica e é uma abordagem bastante realista para desenvolver sistemas de grande porte, pois realiza uma evolução natural do sistema.

Apesar de ainda serem muito utilizados, os modelos tradicionais sofrem duras críticas por seus conhecidos problemas. Segundo Cockburn [14], os métodos tradicionais se esquecem da fragilidade dos engenheiros de software, pois estes não são robôs e exibem grande variedade de estilo, habilidade, criatividade, conhecimento, espontaneidade, entre outras características. Para Larman [39], o software não é algo previsível ou imune a mudanças e seu processo de engenharia deve ser capaz de lidar com estas características. O Manifesto Ágil [8] se originou de uma reunião realizada em Utah, por um grupo de 17 experientes desenvolvedores, consultores e líderes na comunidade de software e seu objetivo era discutir idéias e alternativas às metodologias tradicionais de desenvolvimento de softwares. Nele, foram definidos os seguintes valores:

- Indivíduos e interações são mais importantes que processos e ferramentas;

- Software funcionando é mais importante que documentação completa e detalhada;

- Colaboração com o cliente é mais importante que negociação de contratos; 
- Adaptação a mudanças é mais importante que seguir o plano inicial;

Apesar da importância dos itens à direita, os métodos ágeis dão mais valor aos itens em negrito à esquerda. Fowler [44] descreve que é muito difícil prever todos os requisitos e como serão as prioridades dos clientes ao longo do projeto, que não é fácil medir o quanto deve estar implementado para que a estrutura seja validada e que mesmo um bom planejamento inicial não é capaz de prever tudo o que pode acontecer na construção de um sistema. A seguir são descritos alguns dos principais métodos ágeis.

Os métodos da Família Crystal, propostos por Cockburn [15], têm foco na habilidade individual dos desenvolvedores e na melhoria da comunicação para aumentar a efetividade de projetos de softwares. O método Scrum $[48,49]$ foi desenvolvido nas décadas de 80 e 90 e concentra-se mais nos aspectos gerenciais do desenvolvimento. O método ASD - Adaptative Software Development [23] foi desenvolvido por Jim Highsmith em 1997 e tem um ciclo de vida dinâmico, dedicado ao aprendizado contínuo, orientado a mudanças, reavaliação e intensa colaboração com os usuários.

Por fim, a Programação Extrema [4,6,7], ou XP, é reconhecida, entre outros aspectos, por ser o método ágil de maior visibilidade dos últimos anos. O XP surgiu das idéias de desenvolvedores da comunidade Smalltalk, que buscaram utilizar as boas práticas de software ao extremo. O principal nome do XP é Kent Beck, com diversos trabalhos [4-7, 9,43] que levaram à versão atual método XP. Entre as principais características de XP, está que XP é um método leve que busca implementar apenas o mínimo necessário para uma nova funcionalidade, é voltado ao desenvolvimento de software e busca não se envolver em outras áreas, funciona para times de qualquer tamanho e até para equipes distribuídas [16] e, por fim, se adapta a requisitos vagos e em constante mudança. O método XP é segmentado em três conceitos: os valores, os princípios e as práticas.

\subsection{As Duas Práticas Principais}

A aplicação de práticas ágeis em projetos de DW é um grande desafio e, para tornar possível a junção destes dois conceitos, este trabalho propõe a utilização de duas práticas que, juntas, trazem para projetos de DW alguns dos benefícios encontrados nos projetos ágeis. A primeira delas tem o objetivo de estender o conceito iterativo já existente no método tradicional, reduzindo ao máximo o tempo de entrega de funcionalidades e que será chamada de ciclo iterativo, realizando ciclos curtos de trabalho e, conseqüentemente, fazendo entregas freqüentes. A segunda prática complementa a primeira e tem o objetivo de fazer com que o projeto seja incremental, utilizando os fundamentos teóricos de bancos de dados evolutivos [20,54] para dar o necessário suporte a esta constante evolução, principalmente quanto ao bancos de dados, conforme descrito na Seção 3.2. Estas duas práticas estão descritas na Tabela 4.1. 
Tabela 4.1: As duas principais práticas ágeis para desenvolvimento evolutivo de DW

\begin{tabular}{|l|l|}
\hline Prática Ágil & Aplicação no projeto \\
\hline $\begin{array}{l}\text { Ciclo Itera- } \\
\text { tivo }\end{array}$ & $\begin{array}{l}\text { As definições de prazos curtos, por exemplo de uma semana para entregas peque- } \\
\text { nas e três meses para grupos maiores de funcionalidades, favorecem a organiza- } \\
\text { ção iterativa do projeto e permitem uma entrega constante de funcionalidades, } \\
\text { fazendo com que o resultado do investimento apareça mais rapidamente para } \\
\text { os usuários. }\end{array}$ \\
\hline $\begin{array}{l}\text { Projeto In- } \\
\text { cremental }\end{array}$ & $\begin{array}{l}\text { Para entregar funcionalidades mais rapidamente, a construção do projeto deve } \\
\text { ser incremental, como proposto por Kimball no Capítulo 2, mas com ciclos } \\
\text { menores, em que todo projeto de arquitetura seja incremental. }\end{array}$ \\
\hline
\end{tabular}

A primeira, denominada ciclo iterativo, garante a realização de ciclos mais curtos de trabalho, com escopo reduzido e funcionalidades, definidas neste trabalho por uma técnica de priorização chamada RFV que é detalhada mais adiante neste capítulo. A segunda, chamada de projeto incremental, permite que a arquitetura do projeto evolua gradualmente a cada iteração. A aplicação desta prática significa que, em cada ciclo de desenvolvimento, o processo de ETL precisa se adaptar a novos campos, o banco de dados deve evoluir com o auxílio das técnicas de bancos evolutivos (Capítulo 3) e, também, as ferramentas de BI têm que evoluir os relatórios existentes e implementar novos.

Com a aplicação destas duas práticas, torna-se possível implementar um projeto evolutivo de DW, pois podem ser feitas pequenas evoluções em quaisquer etapas do processo tradicional, inclusive no banco de dados populado. Além disso, a aplicação destas duas práticas torna a engenharia do DW mais aderente à aplicação de outras práticas ágeis que, em maior ou menor escala, passam a contribuir com o projeto. A Tabela 4.2 descreve algumas das práticas que se adaptam bem à estrutura de um projeto como este, que também podem ser aplicadas com as duas principais.

Segue abaixo uma breve descrição de como as práticas ágeis apresentadas podem contribuir na construção do DW:

- A prática de ciclo iterativo é importante para que a entrega de funcionalidades seja feita rapidamente e em ritmo constante, obtendo assim um feedback freqüente do cliente. Esta prática tem forte influência na fase de planejamento, pois é o momento em que o escopo, que precisa ser adequado a um ciclo de desenvolvimento curto, é definido.

- A aplicação da prática projeto incremental é importante em todas as etapas de projeto, fases que se utilizam muito dos requisitos e que são responsáveis por direcionar o trabalho das equipes de desenvolvimento. Em especial, esta prática permite que o banco de dados seja evoluído, tanto por refatorações quanto por transformações em seu esquema. Conseqüentemente, as fases de projeto e desenvolvimento sofrem maior influência do projeto incremental, como mostrado na Figura 4.1.

- A implantação incremental ocorre na fase de integração e implantação, quando as novas 
Tabela 4.2: Outras práticas com características adequadas para aplicação em projetos evolutivos de DW

\begin{tabular}{|c|c|}
\hline Prática Ágil & Aplicação no projeto \\
\hline $\begin{array}{l}\text { Implantação } \\
\text { incremental }\end{array}$ & $\begin{array}{l}\text { Esta prática oferece segurança na substituição de sistemas em produção, com } \\
\text { implantações menores e mais freqüentes, buscando evitar a coexistência de am- } \\
\text { bientes antigos e novos e permitindo voltar rapidamente ao estado anterior, caso } \\
\text { o novo sistema apresente algum problema. }\end{array}$ \\
\hline $\begin{array}{l}\text { Execução de } \\
\text { testes }\end{array}$ & $\begin{array}{l}\text { Executar testes é muito importante para que implantações incrementais tenham } \\
\text { consistência de validação. Não é possível realizar implantações incrementais } \\
\text { freqüentes sem garantir que os novos desenvolvimentos não afetaram caracte- } \\
\text { rísticas em uso no ambiente de produção. }\end{array}$ \\
\hline $\begin{array}{l}\text { Envolvimento } \\
\text { real com o } \\
\text { cliente }\end{array}$ & $\begin{array}{l}\text { Esta prática ajuda a reduzir o número de erros conceituais pois o cliente se en- } \\
\text { volve diretamente no projeto, e pode tirar dúvidas simples dos desenvolvedores, } \\
\text { fazendo com que erros conceituais apareçam mais rapidamente e facilitando o } \\
\text { entendimento quanto ao sistema que deve ser implementado. }\end{array}$ \\
\hline $\begin{array}{l}\text { Negociação } \\
\text { com o cliente }\end{array}$ & $\begin{array}{l}\text { Negociação com o cliente é uma prática importante e muito útil no trabalho } \\
\text { pois oferece a alternativa de renegociar escopos em casos de problemas inespe- } \\
\text { rados e que possam causar atrasos. Isso garante que a qualidade do projeto não } \\
\text { é comprometida, pois o escopo da entrega pode ser reduzido mediante negoci- } \\
\text { ações. }\end{array}$ \\
\hline
\end{tabular}

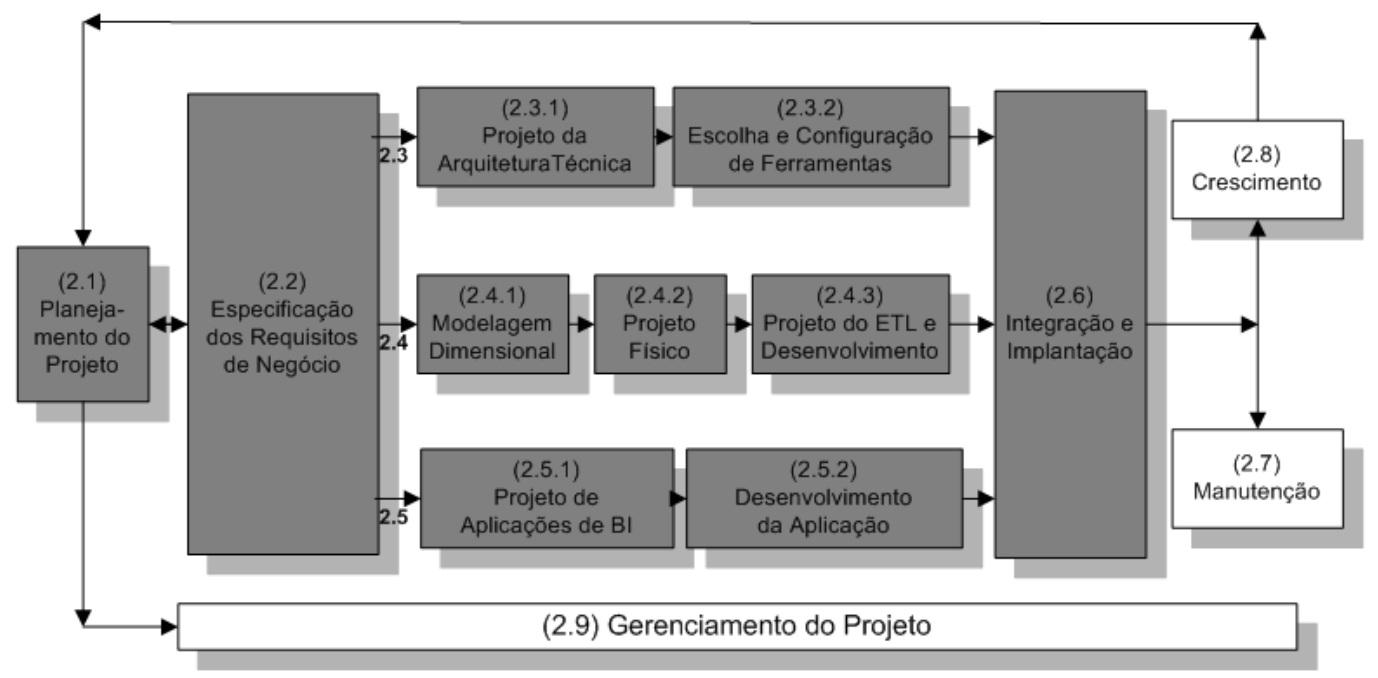

Figura 4.1: Pontos do processo de engenharia mais afetados pela aplicação das práticas ágeis

funcionalidades são migradas ao ambiente de produção. Deve haver uma boa maturidade do processo de desenvolvimento para o sucesso desta prática [7], pois quando um sistema em produção for substituído, todos os testes de validação devem ser executados, da maneira mais automatizada possível, para reduzir o risco de que o novo sistema implantado apresente erros graves e, em caso de problemas, deve ser possível voltar rapidamente ao estado anterior à implantação. 
- A execução de testes é muito importante, mas é muito difícil realizar um desenvolvimento dirigido a testes no projeto, uma vez que, ao contrário dos sistemas de software convencionais, não há grande suporte das ferramentas de ETL para execução de testes unitários automáticos nos processos de carga. Por isso, com implementação e execução manuais, este tipo de teste pode ser utilizado nas etapas mais críticas do processo e uma validação global pode ser feita pela execução de testes diretamente no ambiente final, já carregado. A comparação deste novo ambiente com o anterior, utilizando um backup online, pode ser uma eficiente ferramenta de validação e, quando ocorrer uma nova alteração em alguma tabela do modelo, novos testes podem ser adicionados, para garantir que os sistemas finais ligados à tabela irão apresentar os mesmos resultados.

- O envolvimento com o cliente é de extrema importância para evitar que os desenvolvedores cometam erros conceituais simples, além de garantir sempre a correta priorização das funcionalidades durante a especificação de requisitos.

- Em qualquer projeto podem ocorrer problemas inesperados ao longo do desenvolvimento, o que aumenta o risco de atrasos. Neste caso, a negociação com o cliente garante que a qualidade não seja prejudicada, pois há um canal para manutenção do prazo mediante uma renegociação do escopo.

\subsection{Técnicas para Aplicação das Práticas Ágeis}

Para que a aplicação das práticas ágeis na construção do DW seja bem sucedida, é importante definir claramente como ela será feita. Devem ser usadas técnicas de apoio às duas principais práticas ágeis, para que elas possam ser usadas com eficiência. O primeiro desafio do trabalho está no planejamento do projeto que tem, entre outras coisas, a função de definir o escopo do que será desenvolvido.

É freqüente que, em projetos convencionais, o escopo fique muito grande, o que é uma característica negativa, pois a especificação e todas as etapas de desenvolvimento refletem o seu tamanho. Esta é uma forma de trabalho na qual o cliente prefere pedir tudo o que pode para minimizar o risco de ser posteriormente penalizado por ter esquecido, ou deixado de lado, alguma funcionalidade importante. O conceito de agilidade aplicado ao projeto nos leva por um caminho diferente, de colaboração entre cliente e desenvolvedor, e esta cooperação faz o escopo ter que atender somente às funcionalidades de um ciclo curto (de algumas iterações), com foco em uma versão funcional, associada a um tema.

Ao aplicar princípios ágeis na elaboração do escopo, a prática de "Ciclo Iterativo", descrita na Tabela 4.2, tem forte influência na limitação das funcionalidades da versão do ciclo trimestral, que é desenvolvida em um prazo previamente estipulado de um "trimestre". Estas funcionalidades são dividas em iterações mais curtas, desenhadas para atender o prazo de entrega do ciclo trimestral, 
que deve estar relacionado a um assunto alinhado com as metas e necessidades da empresa. Isto faz o conjunto de funcionalidades do trimestre trazer o maior retorno possível aos usuários e atender ao máximo suas necessidades, alinhando o trabalho de todos os envolvidos com as metas da corporação.

Mesmo com o conhecimento das metas da empresa, não é possível implementar em um ciclo curto tudo aquilo que é parte dos seus objetivos e, por esta razão, é preciso priorizar o que tiver maior importância e que trará maior retorno. Esta necessidade de priorização tem um paralelo conceitual em outra área de estudos que é a segmentação estatística de clientes, que possui uma técnica particular denominada RFV [13,18,24,53] que, em seu contexto original, significa recência, freqüência e valor gasto. A aplicação desta técnica permite às empresas uma identificação eficaz dos clientes que têm maior probabilidade de responder positivamente a ofertas e comunicações e podem assim direcionar seu limitado orçamento para comunicar e oferecer promoções aos clientes certos.

É uma proposta interessante adaptar esta técnica de segmentação ao contexto do trabalho, aplicando-a na identificação dos relatórios que trarão maiores benefícios e facilitando a definição dos campos a serem trabalhados. Para isso, é necessário realizar entrevistas com os usuários do departamento, analisar seus últimos trabalhos relacionados a BI (como os relatórios que desenvolveram e os que utilizaram) e, também, quais executivos recebem os relatórios ou são influenciados por eles. Com estas informações e definido um histórico de análise (por exemplo os últimos 12 meses), a técnica RFV adaptada para relatórios, que será chamada neste trabalho apenas por técnica RFV, pode ser aplicada, assumindo a seguinte definição:

- Recência: permite identificar quando cada relatório foi desenvolvido e agrupá-los no tempo, para priorização de tarefas mais recentes e que estão, portanto, mais alinhadas com os objetivos atuais da empresa.

- Freqüência: quantidade de vezes que um determinado relatório foi utilizado no período estabelecido.

- Valor: o valor do relatório não é medido diretamente por características financeiras, mas pode ser identificado pelos seus destinatários. Assim, o valor de um relatório é determinado por quem o utilizou e a capacidade de decidir é o principal fator de pontuação. Observe que a hierarquia da empresa tem um peso importante, mas não está só. Uma hierarquia menor pode receber pontuação maior, desde que o usuário que está nesta hierarquia realize qualquer tipo de processamento no relatório que possa influenciar hierarquias mais altas e, conseqüentemente, o processo de tomada de decisão como um todo.

Definidas as três variáveis acima, cada relatório deve ter suas notas multiplicadas $\left(\mathrm{R}^{*} \mathrm{~F}^{*} \mathrm{~V}\right)$ e o resultado desta multiplicação permite definir as faixas dos segmentos. Identificados os relatórios mais relevantes, os dados que os compõem devem ser cruzados para identificação de fontes comuns e de 


\section{CAPÍTULO 4. APLICAÇÃO DE PRÁTICAS ÁGEIS EM PROJETOS EVOLUTIVOS DE DW}

padrões de transformações, que possam ser aproveitados em seu desenvolvimento. Se campos de uma mesma tabela transacional são utilizados nos principais relatórios da segmentação, então esta tabela é uma fortíssima candidata a ser uma fonte dos primeiros ciclos de desenvolvimento. Por fim, os campos mais relevantes podem ser utilizados na definição das dimensões do modelo e, também, na definição dos campos que devem ser armazenados nas tabelas de fatos, direcionando os campos do modelo dimensional que devem ser trabalhados na iteração de desenvolvimento. A partir de então, é iniciada a especificação de requisitos de negócio, com a descrição detalhada de cada campo, suas transformações e os relatórios que eles podem compor.

É natural que a dinâmica do negócio demande constantes alterações nas prioridades do cliente e a aplicação da técnica RFV proposta é bastante flexível quanto a estas alterações. No entanto, podem ocorrer situações de dependência temporal onde alterar uma prioridade pode causar inconsistências em alguma funcionalidade da iteração seguinte e, nestes casos específicos, uma alteração de prioridade pode não ser efetuada diretamente, para evitar tais inconsistências.

Além do tamanho do escopo de trabalho, outro grande problema para a viabilidade de projetos evolutivos de DW é a implementação evolutiva no banco de dados, que é um banco carregado com dados históricos e utilizado na geração de relatórios gerenciais. A complexidade de evoluir um ambiente destes está nos dados que, como foi descrito na Seção 3.1, dão vida ao esquema e, em um contexto evolutivo, devem ser tratados de maneira diferenciada.

Refatorar um banco de dados em produção exige a manutenção da semântica comportamental (imediata adaptação de todos os sistemas que acessam a base) e informacional (a mesma informação deve estar no banco de dados antes e depois de sua refatoração). As técnicas de refatoração de bases, descritas no Capítulo 3, mostram as principais evoluções que podem ser aplicadas em bancos de dados e, a partir deste texto, pode-se notar que evoluir uma base dimensional é um caso particular do problema, com características analíticas que têm algumas vantagens na construção de um DW evolutivo.

A aplicação das duas práticas ágeis permite uma constante evolução do DW, aumentando suas funcionalidades após o término de cada ciclo curto de trabalho, oferecendo um pacote de funcionalidades mais completo, entregue ao cliente como uma versão funcional ao final de cada ciclo "trimestral". Cada ciclo de desenvolvimento exige que seja realizada ao menos uma evolução do modelo dimensional após cada iteração, além de outras alterações em diversas outras etapas do processo de engenharia, sendo que as técnicas descritas no Capítulo 3 têm os fundamentos teóricos necessários para estas mudanças.

Quanto à evolução do banco de dados, há fatores favoráveis em trabalhar em um DW, pelas características estruturais deste tipo de banco. Os principais acessos que ocorrem em um DW são de carga (geralmente durante a noite) e de leitura (geralmente durante o dia). Ou seja, não se espera que em um DW seja necessário realizar updates e também não há necessidade de pesados controles 
transacionais. Além disso, o grande volume histórico de dados contido em um DW faz com que a principal forma de acesso às informações seja por consultas agregadas em uma ou mais dimensões analíticas que, em sua maioria, são realizadas por relatórios "estáticos" e por consultas ad-hoc, que ocorrem com menor freqüência.

Estas características favorecem trabalhar um projeto evolutivo de DW pois evoluções realizadas no modelo dimensional, em geral, não demandam alterações corretivas nas consultas feitas pelos relatórios analíticos. É mais fácil perceber estas vantagens ao olhar um exemplo que mostre uma seqüência de evoluções decorrentes da aplicação destas práticas em um DW evolutivo. Além de mostrar a seqüência de evoluções, o exemplo a seguir também identifica as principais evoluções de um projeto evolutivo de DW, de acordo com o Capítulo 3, e quais alterações precisam ser aplicadas nas demais partes do processo, diante das evoluções do modelo dimensional.

\subsection{Aplicação das Práticas Ágeis - Um exemplo ilustrativo}

Ao aplicar as duas práticas ágeis no método de engenharia de Kimball, há uma redução no tamanho das iterações de desenvolvimento ao mínimo possível e é mais fácil que o modelo de dados evolua ao longo as iterações. Com isso, a construção do DW pode ser realizada em passos menores que um data mart completo e, após o término de cada ciclo de desenvolvimento, uma versão funcional do DW pode ser entregue ao usuário, com maiores possibilidades analíticas em relação à versão anterior. A Figura 4.2 mostra a execução de três iterações deste processo modificado do método de Kimball, com a evolução do modelo dimensional após cada iteração.

1 a Iteração

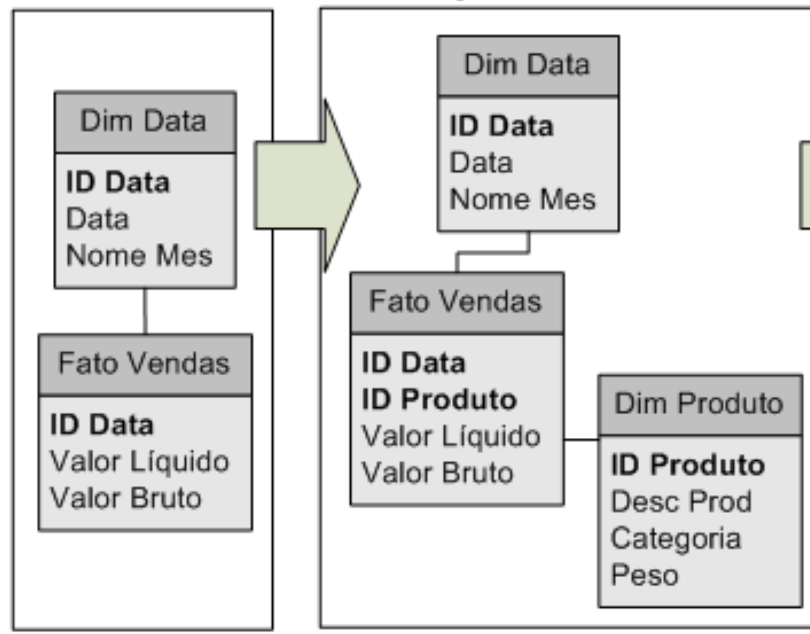

\section{3a Iteração}

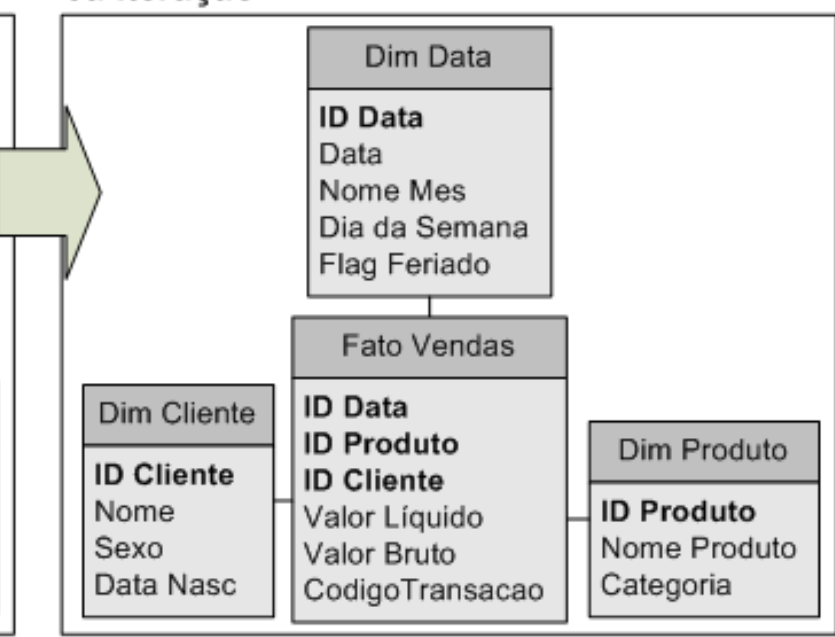

Figura 4.2: Exemplo de três ciclos de desenvolvimento curtos, ou "semanais" 


\section{CAPÍTULO 4. APLICAÇÃO DE PRÁTICAS ÁGEIS EM PROJETOS EVOLUTIVOS DE DW}

O escopo do ciclo trimestral foi definido como um conjunto de campos que para visualização de quais produtos foram vendidos a quais clientes, em cada dia. Análises de valor líquido e valor bruto seriam necessárias e, também, o código da última transação realizada no dia. Esta definição de campos foi a base para a estruturação da versão funcional do trimestre, posteriormente quebrado em três iterações menores, para ciclos rápidos. A visualização do modelo dimensional após cada iteração está na Figura 4.2 e é explicada em detalhes a seguir.

1. Na primeira iteração, o conjunto básico de dados escolhido para entrega foi a tabela de fatos "Vendas" e a dimensão "Data". Foram implementados na tabela de fatos duas métricas: "valor líquido" e "valor bruto" e a dimensão Data foi implementada com seu identificador numérico e com os campos "data" e "nome mes". Após a implementação e entrega deste pequeno modelo dimensional, consultas analíticas de valores (líquidos e brutos) já podem ser realizadas na dimensão de tempo. Como exemplos de possíveis análises neste conjunto de dados, pode-se citar a evolução das vendas ao longo de períodos de tempo, comparativos de valores vendidos em períodos de tempo distintos, entre outras.

2. Na segunda iteração, foi adicionada apenas uma dimensão ao modelo: a dimensão "Produto", composta por um identificador numérico, pelo campo "desc prod" que é a descrição do produto e pelos campos "categoria" e "peso". A partir desta iteração, o usuário já é capaz de detalhar suas análises, incluindo a variável produto em seus relatórios, o que lhe permite uma maior sofisticação analítica.

3. Finalmente, na terceira iteração, foi adicionada uma dimensão "Cliente", com um identificador numérico e dados como "nome", "sexo" e "data de nascimento". Além disso, a dimensão Produto sofreu uma transformação e uma refatoração: a primeira foi a remoção do campo "peso" e a segunda foi a alteração do nome da coluna de descrição do produto, inicialmente chamada "desc prod" e que, após a alteração, passou a se chamar de "nome produto". Com esta terceira entrega, as possibilidades de análise dos usuários são ainda mais amplas e ele pode compor um número muito maior de relatórios no DW.

É importante destacar que, no ciclo de desenvolvimento normal de um DW, o usuário teria que esperar que todas estas informações estivessem disponíveis e implantadas para, somente então, começar a usá-las. Neste processo adaptado, a aplicação das práticas ágeis possibilitam que o usuário receba em um curto período de tempo (o necessário para o término de cada iteração), uma base de dados parcial, porém de valor significativo, que permite que uma série de análises sejam efetuadas muito antes que o DW esteja finalizado.

Entre os ciclos de desenvolvimento descritos na figura 4.2, é muito importante que haja um adequado versionamento do processo, que consiste principalmente em realizar backups dos objetos do banco de dados e em todo o seu processo de carga. A Figura 3.2 apresenta um diagrama com os 
passos para evoluir o banco de dados, que faz referência a este processo de versionamento, apesar de não tratar especificamente do processo de ETL, fundamental em um projeto de DW. Assim como o banco de dados, o processo de ETL e as aplicações de BI que acessam o banco têm que ser versionadas juntas pois, diante de um eventual problema de implantação, é possível restaurar o backup da última versão funcional do processo.

Este exemplo deixa claro também que, com a aplicação das práticas ágeis, a base de dados deve sofrer alterações freqüentes, mas estas alterações ocorrem de forma controlada, já que uma iteração no processo modificado do método de Kimball representa a execução completa de um ciclo de engenharia. Assim, a primeira fase afetada é o "planejamento", seguida pela "especificação de requisitos" e pelas etapas de projeto e desenvolvimento. A seguir, é apresentado um exemplo que mostra a estabilidade dos relatórios no modelo dimensional diante destas constantes mudanças do esquema.

\subsection{A Estabilidade Estrutural}

A evolução do modelo de dados no exemplo da Figura 4.2 mostra o objetivo final de cada iteração, sob a perspectiva do usuário do DW, que pode utilizar, a cada entrega no final da iteração, as novas funcionalidades desenvolvidas. No entanto, uma alteração na fase da modelagem dimensional exige desenvolvimentos em praticamente todas as outras fases do processo de engenharia. Os novos campos adicionados na iteração precisam ter todo seu processo de ETL desenvolvido ou adaptado e testes precisam ser criados para garantia de sua qualidade. Além disso, eles podem passar a fazer parte dos relatórios de BI, ou mesmo dar origem a novos relatórios.

É interessante observar no exemplo anterior que, mesmo com as diversas adições de tabelas e de colunas, mesmo com a troca do nome de uma coluna e com a remoção de outra e com alterações nas próprias tabelas utilizadas, nenhuma adaptação foi necessária na consulta da Figura 4.3, que se manteve funcional ao final de todas as iterações do exemplo. Naturalmente, há situações em que alterações seriam necessárias quando, por exemplo, o nome de alguma das tabelas ou colunas utilizadas sofrer mudança. No entanto, a maioria das evoluções que são aplicadas durante o desenvolvimento do projeto são de inclusão de tabelas e de campos. Assim, relatórios são normalmente alterados para que fiquem mais completos, fazendo uso dos novos campos, e não por terem deixado de funcionar.

Apesar desta maior estabilidade dos relatórios diante das evoluções de banco realizadas em uma iteração, há diversas outras etapas do processo de engenharia que devem ser alteradas para se adequar às mudanças. Dentre elas estão a trilha dos dados (Seção 2.4), composta pela modelagem dimensional, que é o ponto de partida depois das definições da fase de análise de requisitos, pelo projeto físico da base e pelo processo de projeto e desenvolvimento do ETL. Além disso, a trilha das aplicações de BI (Seção 2.5) também deve ser alterada, para que os novos desenvolvimentos 


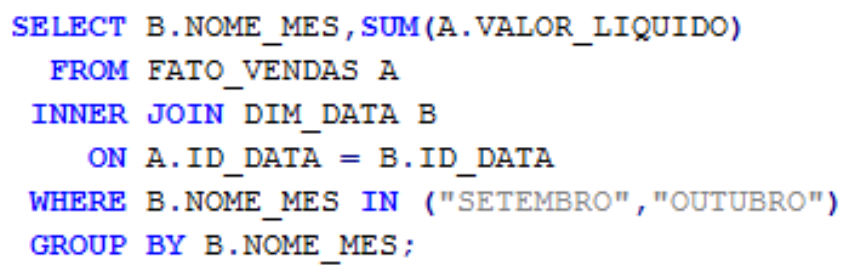

Figura 4.3: Exemplo de consulta, que mostra a estabilidade do modelo dimensional diante a evoluções comuns na construção de um DW evolutivo

reflitam na interface do usuário. Quando houver necessidade de crescimento da infra-estrutura do projeto, podem ocorrer também alterações na trilha da tecnologia (Seção 2.3), para atender esta evolução estrutural.

\subsection{Enumeração das Evoluções}

Pelo fato de um DW utilizar o modelo dimensional, é possível enumerar as principais alterações evolutivas que podem ocorrer, dividindo-as em duas categorias: as evoluções de tabelas de fatos e as evoluções de tabelas dimensionais. Estas categorias (fatos e dimensões) são conceitualmente bem definidas, pois há uma visão clara do que cada uma delas armazena, de como são carregadas e acessadas e, também, quais as possíveis formas de historização de cada uma. A partir do exemplo da Figura 4.2, é feita agora uma análise de cada iteração, com todas as refatorações que foram aplicadas em cada uma delas.

Nas evoluções do exemplo da Figura 4.2, é interessante reforçar que cada ciclo de desenvolvimento tem todos os passos do processo de engenharia de DW, de acordo com o Capítulo 2. No texto abaixo são descritas características particulares de cada iteração em relação às evoluções do modelo dimensional e também às possíveis adaptações ágeis que podem ser aplicadas no processo. Para uma visão mais completa dos tipos de refatorações e de transformações, o Apêndice A faz um maior aprofundamento neste tópico.

A fase de planejamento é responsável pela definição do escopo de trabalho da primeira versão funcional. $\mathrm{O}$ assunto escolhido no exemplo é relativo à estrutura de vendas da empresa, para que análises sobre clientes e produtos pudessem ser feitas no tempo. A escolha do assunto e dos campos foi facilitada pela técnica RFV, pela identificação do que é mais prioritário para a empresa e alinhando o desenvolvimento com estas prioridades. A definição do escopo do ciclo trimestral possibilita a criação de ciclos menores de trabalho que, neste exemplo, são três iterações. Juntas, esta iterações correspondem à primeira versão funcional do DW.

\section{1a Iteração:}


A primeira iteração tem uma importância diferenciada, pois é o momento onde toda a estrutura tecnológica é montada e configurada pela primeira vez, as ferramentas são escolhidas e testadas. No desenvolvimento da iteração, foram escolhidas duas tabelas: a tabela dimensão data e a tabela fato de vendas, com três colunas em cada uma.

Será utilizado desde o início os termos "refatoração" ou "transformação", mesmo quando o banco ainda está vazio e os primeiros objetos do DW estão sendo criados. Assim, as evoluções apresentadas a seguir são aplicadas na primeira iteração e um maior detalhamento da implementação de cada uma delas pode ser encontrado no Apêndice A.

- Adicionar tabela: esta transformação é aplicada nas duas tabelas Dim_Data e Fato_Vendas.

- Adicionar coluna: aplicada nas seis colunas que são adicionadas: Na tabela Dim_Data, os campos ID_Data, Data e Nome_Mes. Na tabela Fato_Vendas, as colunas ID_Data, Valor_Liquido e Valor_Bruto.

- Adicionar índice: aplicada nas colunas ID_Data das duas tabelas em que este campo está presente.

- Adicionar chave estrangeira: aplicada na fato de vendas, para garantir a integridade referencial da tabela de fatos. O campo Fato_Vendas.ID_Data deve referenciar (via Foreign Key) o campo Dim_Data.ID_Data.

Após a atualização dos modelos dimensional e físico, é preciso adaptar o processo de carga ETL para que as novas tabelas sejam carregadas, passando por todo o processo de extração, limpeza, padronização e finalmente a carga nas tabelas do DW. A etapa de extração, realizada pelo processo ETL, é um bom momento para realizar testes, validando a qualidade dos dados recebidos dos sistemas transacionais antes de iniciar maiores processamentos. Diversos cenários de validação podem ser criados, por exemplo, para garantir a correção dos campos utilizados nos cálculos das métricas de valores, na tabela de fatos.

O processo de ETL também pode ter alguns testes unitários e algumas validações automáticas podem ser implementadas, para garantir que o processo esteja funcionando adequadamente. Para tanto, as validações citadas no Capítulo 2 devem ser tomadas como referência na elaboração destes testes. Pode-se, por exemplo, testar os dados de saída do processo de padronização no campo Nome_Mes, para garantir que todos os registros tenham conteúdo padronizado e também que apenas existam 12 meses válidos.

Além da trilha de dados, também pode haver necessidade de adaptação da trilha das aplicações de BI e, nesta primeira iteração, são desenvolvidos os primeiros relatórios do projeto, de acordo com o documento de requisitos, que é onde estão suas definições. A maioria dos relatórios de acesso ao DW têm formato fixo e fazem muito uso de agregações (na 1a iteração, há somente uma dimensão de tempo e, portanto, apenas são possíveis análises temporais das métricas). 
Após o término dos desenvolvimentos e quando todos os testes estiverem sendo executados sem erros, o sistema completo pode ser implantado em produção. Uma carga histórica inicial deve ser realizada para que a primeira versão do DW seja disponibilizada. A próxima iteração pode então começar e os desenvolvedores voltam à fase de planejamento do projeto.

2a Iteração: Na segunda iteração são feitas melhorias no modelo dimensional para dar uma maior capacidade analítica dos usuários do DW, e é novamente para atender o escopo da versão funcional, que foi feita a implementação de uma dimensão de produtos. A dimensão deve ser implementada inicialmente com quatro colunas e, após a adaptação do modelo, todos os processos relacionados ao DW devem, também, se adaptar a esta nova tabela. Inicialmente, para alterar o modelo dimensional, foram feitas as evoluções descritas a seguir. Detalhes de implementação e exemplos de códigos podem ser encontradas no Apêndice A.

- Adicionar tabela: aplicada uma vez, na adição da tabela Dim_Produto.

- Adicionar coluna: aplicada nas quatro colunas da tabela produto, que são ID_Produto, Desc_Prod, Categoria e Peso. Ela é aplicada também na adição da coluna ID_Produto da tabela Fato_Vendas.

- Adicionar índice: aplicada no campo ID_Produto de cada uma das duas tabelas em que o campo está presente.

- Adicionar chave estrangeira: esta refatoração é aplicada na fato de vendas, para garantir a integridade referencial da tabela de fatos. O campo Fato_Vendas.ID_Produto deve referenciar (via Foreign Key) o campo Dim_Produto.ID_Produto.

As evoluções desta segunda iteração são análogas às aplicadas na primeira e, por isso, toda a mecânica de adaptação do processo de ETL deve ser executado da mesma forma. As alterações na trilha de dados também seguem o mesmo padrão e evoluem de acordo com as necessidades descritas na especificação de requisitos, que pode ainda demandar alterações em relatórios existentes para adaptar os novos campos ou para a criação de novos relatórios. Outras aplicações de BI também podem ser implementadas, como simuladores e ferramentas de mineração de dados.

Novamente, após o término dos desenvolvimentos e quando os testes forem executados sem erros, os desenvolvimentos da 2a iteração podem ser implantados em produção e a próxima iteração de desenvolvimento pode ser iniciada.

3a Iteração: A terceira iteração do processo tem características um pouco diferentes das duas primeiras. Para a evolução do modelo dimensional são aplicadas as mesmas evoluções das primeiras iterações e também duas novas alterações, ambas na dimensão de produtos: na primeira, 
um dos campos foi removido e, na segunda, foi alterado o nome de uma coluna da tabela, que não refletia claramente para os usuários o real significado do campo. Estas refatorações são descritas a seguir e detalhes de sua implementação e exemplos de códigos podem ser encontradas no Apêndice A.

- Adicionar tabela: é aplicada uma única vez nesta última iteração, na adição da tabela Dim Cliente.

- Adicionar coluna: é aplicada nas quatro novas colunas da tabela cliente, que são ID_Cliente, Nome, Sexo e Data_Nasc. Aplicar também na adição da coluna ID_Cliente da tabela Fato_Vendas.

- Adicionar índice: aplicada nas duas chaves numéricas da nova tabela Dim_Cliente e da tabela Fato_Vendas. O índice é adicionado para os campo ID_Cliente de cada uma das destas tabelas.

- Adicionar chave estrangeira: aplicada na fato de vendas para garantir a integridade referencial da tabela de fatos. O campo Fato_Vendas.ID_Cliente deve referenciar (via Foreign Key) o campo Dim_Cliente.ID_Cliente.

- Remover coluna: esta transformação é aplicada na tabela dimensional Dim Produto para remover o campo "peso" da tabela, pois houve um erro na especificação de requisitos e este campo não deveria estar nesta tabela.

- Renomear coluna: a coluna de "Desc_Prod" tinha um nome inadequado e que causava algum desvio de conceito. Por isso, o campo sofre esta refatoração e a coluna é renomeada para "Nome_Produto".

As quatro primeiras evoluções descritas nesta terceira iteração são análogas às aplicadas nas duas primeiras e, por isso, toda a mecânica de adaptação do processo de ETL é executado da mesma forma. O mesmo ocorre para as alterações nos processos da trilha de dados, que é análogo, lembrando que podem ocorrer alterações em relatórios existentes, tanto para adição, remoção ou alteração de campos quanto para criação de novos relatórios, de acordo com as necessidades dos usuários.

Quanto à remoção do campo, há dois possíveis cenários: no primeiro, o campo não é necessário em nenhuma outra tabela em todo o DW e deve ser completamente removido. Neste caso, o modelo dimensional é o primeiro a ser alterado, seguido pelo modelo físico. Detalhes e códigos fontes podem ser vistos no item 2 do Apêndice A.

Após a alteração física das tabelas, o processo de carga ETL precisa ser adaptado e todas as referências ao campo podem ser removidas. Além disso, testes relacionados a este campo devem ser adaptados ao novo esquema e o mesmo processo de remoção deve ser realizado na trilha das aplicações de BI, nas interfaces de usuário. 


\section{CAPÍTULO 4. APLICAÇÃO DE PRÁTICAS ÁGEIS EM PROJETOS EVOLUTIVOS DE DW}

O segundo cenário ocorre quando o campo não deve ser completamente removido do DW pois ele pertence (corretamente) a alguma outra tabela e, neste caso, ele deve ser removido apenas do sub-processo ETL correspondente. Ainda neste segundo cenário, pode ocorrer que a remoção seja ainda mais trivial, como apenas em um determinado relatório de usuário e, neste caso, somente a aplicação de BI deve ser alterada, sem prejuízo à base de dados, que pode manter a mesma estrutura.

Quanto à última refatoração do exemplo, de renomear uma coluna do esquema, deve-se ter segurança de que os benefícios da alteração compensam o trabalho a ser realizado pois, dependendo do nível de acoplamento do sistema, apresentado na Figura 3.1, pode ser necessário uma considerável manutenção no processo e, para realizar este esforço de desenvolvimento, o benefício deve ser ao menos equivalente. Além disso, a manutenção de consistências, pode amplificar o trabalho pois se um campo de nome VTOT for renomeado para VALOR_TOTAL, então deve-se garantir que todas as tabelas em que este campo estiver presente sejam alteradas.

Caso os benefícios compensem o trabalho, então os passos descritos no item 3 do Apêndice A podem ser executados, pois baseiam-se nos passos de refatoração propostos por Ambler [54], com códigos e procedimentos adequados a uma refatoração de base bem sucedida. No restante da trilha de dados e também na trilha de BI, o nome antigo deve ser adaptado ao novo nome para manutenção da consistência global do projeto.

\subsection{Resumo do Capítulo}

Este capítulo foi iniciado com uma rápida e bastante referenciada introdução sobre engenharia de software e modelos de processos de engenharia. Em seguida, foi feita uma discussão sobre o surgimento dos métodos ágeis, o manifesto ágil e uma introdução a alguns dos principais métodos. As referências dos métodos ágeis foram bastante completas e o leitor que tiver interesse pode buscar mais informações sobre quaisquer dos assuntos.

Em seguida, foi feita uma proposta para aplicação de práticas ágeis no processo de engenharia tradicional de DW, a partir de modificações no processo descrito no Capítulo 2. As modificações foram iniciadas pela aplicação de duas práticas ágeis, seguidas por outras que também entraram no processo por alguma dependência ou que passaram a ter uma maior propensão para serem utilizadas. Em seguida, foi dado um exemplo ilustrativo (Figura 4.2) da aplicação destas práticas ágeis e, com o auxílio deste exemplo, foi descrita a estabilidade estrutural que o modelo dimensional possui na

aplicação desta proposta de DW evolutivo. Por fim, também a partir do exemplo, foi feita uma enumeração descritiva das refatorações e transformações aplicadas no modelo analítico. 


\section{Capítulo 5}

\section{Exemplo de Aplicação}

\subsection{A empresa}

Neste capítulo é apresentado um exemplo de utilização de práticas ágeis em um projeto de DW evolutivo. São descritas as primeiras iterações do projeto, construído de acordo com os passos do Capítulo 4, em uma implementação realizada para uma empresa do setor de crédito ao consumidor chamada Cetelem. Presente no Brasil desde 1999, a Cetelem atua em parceria com alguns dos grandes líderes dos diversos segmentos do varejo brasileiro tais como Carrefour, Telha Norte, Submarino, Fnac, Fast Shop, entre outros parceiros. No final de 2008, a Cetelem também adquiriu o banco BGN, especialista do mercado do crédito consignado.

A empresa é líder na Zona Euro e está presente em mais de 30 países, com mais de 24 mil colaboradores e é responsável pela administração de uma carteira de crédito superior a 83 bilhões de Euros pelo mundo. A Cetelem faz parte do grupo BNP Paribas, um dos maiores grupos bancários internacionais, presente no Brasil e em mais de 85 outros países, classificado por agências internacionais como um dos 4 bancos mais sólidos do mundo [17,46] e eleito o banco do ano de 2008 pela revista "The Banker".

O projeto apresentado nesse capítulo trata das primeiras etapas de desenvolvimento de um data mart de CRM, um departamento responsável por diferentes atividades, como seleção de público para campanhas de marketing, realização de estudos estatísticos e entrega de relatórios analíticos a gestores. A implementação do projeto foi dividida em três iterações curtas, e abaixo está a descrição de cada uma destas iterações.

\subsection{A 1a iteração}

Esta iteração, que é a primeira do ciclo trimestral, tem a importante função de definir as funcionalidades que serão desenvolvidas no trimestre, de acordo com as prioridades do cliente. Este ciclo 
maior dá origem a etapas menores, que podem ser até semanais, mas que têm como objetivo principal alcançar as metas do ciclo trimestral, que é chamado a partir de agora de versão do trimestre.

\subsubsection{Planejamento}

Após a realização de entrevistas e o levantamento de dezenas de relatórios e estudos em um histórico aproximado de 12 meses, a técnica RFV foi aplicada conforme descrito na Seção 4.3, com o auxílio dos usuários, responsáveis pelos parâmetros da segmentação. Os relatórios mais relevantes tiveram uma análise mais aprofundada, com a identificação das tabelas fontes, dos campos e das regras comuns a cada um e, com isso, foram identificados padrões para a definição de um escopo pequeno mas capaz de agregar valor ao ambiente analítico. Após esta análise, ficou clara a importância do produto cartão de crédito, que foi escolhido como o assunto a ser tratado na versão do trimestre. Além disso, facilitou o fato de que os dados comuns destes relatórios se encontram em poucas tabelas transacionais, o que facilita um desenvolvimento mais rápido do ETL, uma das etapas mais complexas na construção do DW.

Definido o escopo do ciclo trimestral, foi possível fazer um rascunho de planejamento para três iterações. A primeira delas ficou pequena, pois foram levados em conta todos os problemas iniciais que podem ocorrer em um projeto que envolve tantas tecnologias, em que muitas ferramentas ainda teriam que ser instaladas e configuradas gerando um natural atraso no desenvolvimento. Conforme apresentado a seguir na especificação de requisitos, a primeira iteração permitiu uma estruturação do ambiente e, ao mesmo tempo, que o desenvolvimento pudesse trazer uma estrutura analítica mínima com algum relatório funcional, fechando um ciclo completo de desenvolvimento, estruturação das ferramentas e das tecnologias, com tudo integrado ao final da iteração.

\subsubsection{Especificação de requisitos}

Assim, o cruzamento de informações do cartão com dados de produtos, em uma análise sobre a dimensão de tempo, definiram a estrutura básica dos relatórios e, a partir deste eixo central, o documento de requisitos pôde ser elaborado. Para esta tarefa, não é preciso desenvolver longos documentos descritivos, mas sim documentos curtos e objetivos, com uma definição clara das metas do ciclo trimestral e com rascunhos (separados do documento principal) do que deve ser feito nas iterações até o término da versão do trimestre. A iteração atual é a única que, neste momento, deve ter uma especificação clara, pois é nela que os desenvolvedores irão trabalhar, e é uma tarefa que foi facilitada pela fase de planejamento do projeto, que realizou uma boa parte da engenharia de requisitos.

A trilha de tecnologia pode receber antecipadamente toda a especificação do ciclo trimestral, 
Tabela 5.1: Estrutura da especificação de requisitos

\section{Estrutura do documento de especificação de requisitos}

\section{- Cabeçalho}

Autores, data do documento, controle de alterações.

\section{- Introdução}

Uma visão geral do projeto para o leitor, explicando o método iterativo de trabalho e o ambiente do projeto.

\section{- Requisitos funcionais e não-funcionais}

Na descrição dos requisitos funcionais, foram utilizados exemplos de relatórios, destacando as necessidades de interação dos usuários e as formas atuais de disponibilização destes relatórios. Para os requisitos não-funcionais, foi definido o desempenho esperado na visualização e manipulação dos relatórios, o volume de dados que seria lido e o tempo máximo para a carga, informações importantes para a seleção de ferramentas adequadas.

\section{- Requisitos de software e hardware}

Listagem de todos os novos softwares e hardwares, cuja necessidade seja previamente conhecida. Após a primeira iteração, somente são descritas nesta etapa as alterações na estrutura. Caso não seja especificado diretamente o software, a equipe de compras corporativas pode ir buscar soluções no mercado para as necessidades da iteração, solicitando provas de conceitos (também conhecidas como POCs) para seleção dos melhores fornecedores.

\section{- Fontes de dados}

Especificação das fontes do projeto, em um documento que os apresente campo a campo, trazendo quaisquer detalhes que facilitem o posterior desenvolvimento do processo de ETL. Deve haver uma separação dos campos a serem desenvolvidos em cada iteração, pois este mesmo documento é utilizado ao longo de todas as iterações do ciclo trimestral, sendo apenas atualizado no início de cada uma.

\section{- Glossário de termos técnicos}

Dicionário para os termos técnicos ou específicos do negócio.

pois ela irá prover a estruturação tecnológica para as equipes de desenvolvimento trabalharem nos ciclos subseqüentes. Dessa forma, a estrutura da especificação de requisitos ficou definida conforme o modelo da Tabela 5.1 e o documento foi criado, com a preocupação de atender aos três eixos de desenvolvimento paralelo que viriam a seguir: a trilha da tecnologia, a trilha dos dados e a trilha das aplicações de BI (seções 2.3, 2.4 e 2.5). O objetivo inicial traçado foi para atender, em três iterações pequenas (de no máximo duas semanas cada), um pequeno conjunto básico de dados 
para relatórios do produto cartão. Cada iteração deve adicionar ao documento de requisitos as novas informações pertinentes à sua iteração, incrementando o documento e o mantendo como uma fonte centralizada das informações do projeto.

\subsubsection{Trilha da tecnologia}

A trilha da tecnologia deve ser priorizada após a especificação de requisitos, pois é aqui que se monta a estrutura de trabalho das demais frentes de desenvolvimento. Assim, tanto a trilha dos dados quanto a trilha das aplicações de BI precisam ter sua estruturação tecnológica preparada o quanto antes, para que possam ser concluídas mais rapidamente.

Nesse estudo de caso, foram identificadas as necessidades tecnológicas para o desenvolvimento do processo e a entrega dos relatórios, que podem ser divididas em duas frentes, uma de hardware e outra de software, em que as necessidades de hardware dependem das tecnologias e dos sistemas que forem escolhidos e aplicados no projeto. A Tabela 5.2 apresenta um resumo dos requisitos de hardware, enquanto a Tabela 5.3 apresenta as necessidades e as soluções aplicadas para suprir as demandas de softwares.

Tabela 5.2: Requisitos de hardwares para o projeto

\section{Trilha da tecnologia: Requisitos de hardware}

1. Ambiente de desenvolvimento: devem ser disponibilizadas dois desktops de desenvolvimento, com toda a instalação de softwares clientes para as ferramentas do ambiente e as máquinas devem ter uma configuração adequada de hardware para utilização destes softwares.

2. Servidores: os servidores devem ser montados em três ambientes: desenvolvimento, homologação e produção, sendo que este último precisa de uma configuração muito superior aos dois primeiros.

Com a especificação dos softwares e hardwares necessários, a etapa de projeto da arquitetura técnica é iniciada e começa a estruturação tecnológica do ambiente analítico. As ferramentas que já são utilizadas na empresa têm preferência, por já terem passado por um processo de seleção e aprovação. Além disso, ampliar contratos existentes costuma ser uma opção mais em conta do que contratar novos fornecedores. 
Tabela 5.3: Requisitos de softwares para o projeto

\section{Trilha da tecnologia: Requisitos de software}

\begin{tabular}{l}
\hline Requisito tecnológico \\
Ferramenta de qualidade de dados: deve va- \\
lidar os dados dos arquivos fontes, para assegu- \\
rar sua qualidade e evitar problemas no processa- \\
mento ETL.
\end{tabular}

Sistema gerenciador de banco de dados: Há necessidades de armazenamento pequenas inicialmente, mas a ferramenta deve ser escalável em disco e processamento, dado o objetivo de construir neste ambiente um DW.

Ferramenta de modelagem de dados: a ferramenta precisa de uma interface gráfica simples e adequada para criação e gerenciamento do modelo de dados. A ferramenta também deve ser compatível com o SGBD que for escolhido, permitindo manipulação estrutural direta e, portanto, um sincronismo contínuo entre eles.

Ferramenta de ETL: deve ter um bom desempenho e também ser de fácil gerenciamento, conforme descrito na Seção 2.4.3. Características básicas de processamento, como permitir agregações, lookup e ter suporte a processamento paralelo são características essenciais.

Ferramenta de BI: ferramenta de mercado para a geração de relatórios analíticos. Deve permitir a entrega de relatórios pela Web, um importante canal para disponibilizar os relatórios de BI.

\section{Solução adotada}

Foi selecionada uma ferramenta chamada Coflux, desenvolvida pela própria Cetelem em sua matriz francesa, que aplica regras de controle de qualidade e monitoramento diretamente nos arquivos de dados.

O banco de dados Oracle foi escolhido, principalmente por já pertencer à estrutura de outro projeto no ambiente de marketing e sua capacidade foi ampliada para o projeto.

Foi utilizado o Erwin, da Computer Associates, mas sua utilização ainda estava limitada ao período de avaliação. A ferramenta se mostrou bastante adequada aos propósitos do projeto, mas caso não seja a ferramenta escolhida pela equipe de compras, pode haver ainda alguma alteração.

A ferramenta de ETL selecionada foi o Datastage, da IBM, pois já é utilizada em outro projeto do departamento e tem todas as características necessárias e desejáveis.

Foi escolhido o Microstrategy, uma ferramenta muito poderosa para apresentação de relatórios e para a manipulação OLAP.

\subsubsection{Trilha dos dados}

A trilha de dados se inicia pela modelagem dimensional, que tem a função de elaborar uma estrutura adequada aos propósitos analíticos, como descrito em 2.4.1. O assunto do primeiro modelo dimensional já está escolhido e é sobre produtos ligados ao cartão de crédito ou, mais especificamente, trata as possíveis movimentações que um cartão de crédito pode realizar. Naturalmente, um cartão pode adquirir vários produtos por dia, inclusive um mesmo produto pode ser adquirido várias vezes no mesmo dia. O nível de detalhamento da tabela de fatos deve ter, ao final do ciclo trimestral, o conjunto de utilizações de um cartão por produto, por dia.

Apesar da definição da tabela de fatos ao final do ciclo trimestral, a iteração tem um objetivo 
menor e, naturalmente, não atinge este nível de detalhamento. A primeira iteração é composta apenas por informações totais de compras no tempo. Os dados de produtos e de cartão não estão inclusos nesta fase e isso reduz consideravelmente o tamanho da tabela de fatos. Desta forma, foi definida apenas a dimensão Tempo no modelo da 1a iteração, que foi associada a uma tabela de fatos de Movimento Cartão, com duas métricas analíticas: a quantidade e o montante gasto no dia. A Figura 5.1 traz o modelo lógico que representa esta estrutura.

Após a definição do modelo lógico, a estruturação física destas tabelas foi feita, conforme descrito no capítulo de projeto físico na Seção 2.4.2. A padronização da nomenclatura é a primeira tarefa e sua importância é grande pois, no contexto iterativo de desenvolvimento, uma nomenclatura inadequada poderia se tornar um obstáculo ao crescimento em fases mais avançadas e esforços de padronização de nomes poderiam ser necessários.

O padrão de nomes do projeto ficou estabelecido da seguinte forma: para tabelas e views, a nomenclatura se inicia com dois caracteres "TB" ou "VW", seguida por uma seqüência de três caracteres que determinam sua natureza dimensional, por exemplo "FAT" para tabelas de fatos ou "DIM" para dimensões e, a seguir, o nome lógico da tabela é mapeado para grupos de quatro caracteres. Cada um destes grupos foi separado por um caractere "-" e, pegando como exemplo a tabela de fatos, seu nome físico foi mapeado de "Fato Movimento Cartão" para "TB_FAT_MVTO_CART".

Para as colunas das tabelas, o padrão ficou parecido, com os dois primeiros caracteres indicando o tipo de dados tratado, como "ID" para valores de chave, "DS" para strings descritivas, "NB" para números, "DT" para datas, etc. A ferramenta de modelagem permitiu um mapeamento direto entre os nomes definidos no modelo lógico e os nomes físicos, através de um arquivo centralizado que, além de gerar a DDL das tabelas físicas no padrão de nomes estabelecido, também garante que nomes lógicos coincidentes sejam mapeados para o mesmo grupo de caracteres. Por exemplo, uma outra tabela qualquer que tenha a palavra "Movimento" será automaticamente mapeada para o grupo de caracteres "MVTO", reduzindo as chances de inconsistências por intervenções manuais. Com estas regras, o modelo físico da 1a iteração ficou conforme apresentado na Figura 5.2.

O modelo físico representa a real estrutura de armazenamento interno e, por esta razão, as evoluções descritas na Seção 3.5 foram definidas e aplicadas nesta etapa. A primeira iteração não é um problema, pois o ambiente ainda está vazio, mas a partir da segunda iteração os dados se tornarão parte do processo de evolução e podem precisar de algum tratamento especial. A descrição das evoluções da iteração é a seguinte:

- Adicionar tabela: esta transformação foi aplicada nas duas tabelas "TB_DIM_TMPO" e também na "TB_FAT_MVTO_CART".

- Adicionar coluna: aplicada em todos os campos que serão adicionados, sendo três da tabela "TB_FAT_MVTO_CART" e o restante da tabela "TB_DIM_TMPO". Naturalmente, a adição 


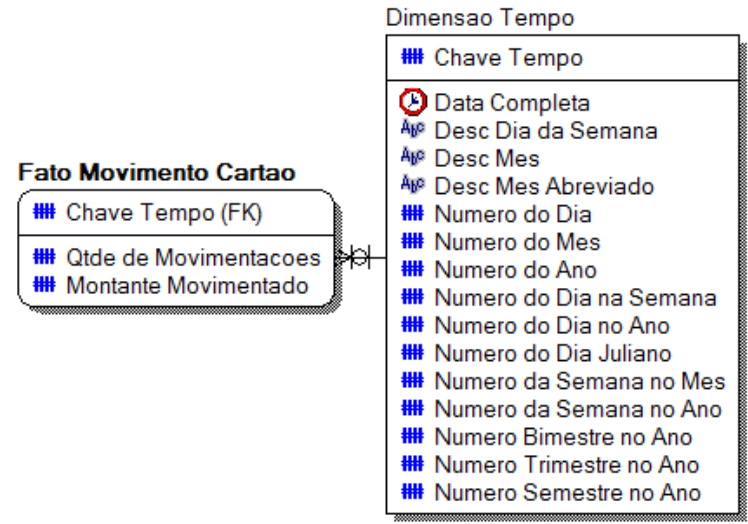

Figura 5.1: Modelo lógico da 1a iteração

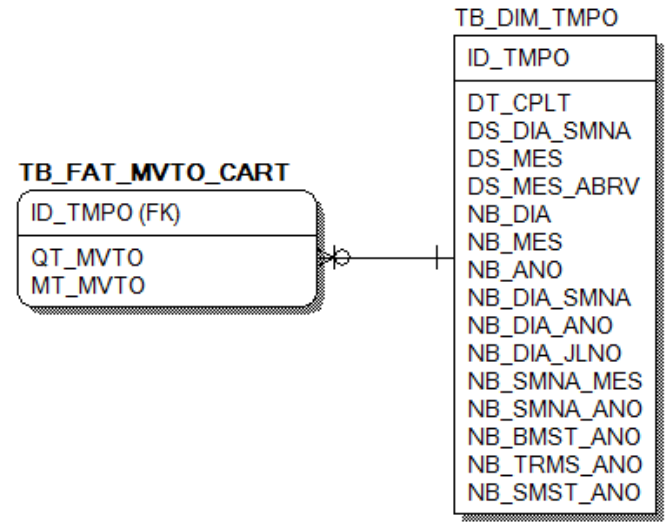

Figura 5.2: Modelo físico da 1a iteração

da tabela tem maior precedência, e estas adições de colunas podem ser desnecessárias quando a iteração de criação de sua tabela.

- Adicionar índice: aplicada individualmente em cada campo chave das duas tabelas, que é o campo ID_TMPO das tabelas "TB_FAT_MVTO_CART" e "TB_DIM_TMPO".

- Adicionar chave estrangeira: aplicada na "TB_FAT_MVTO_CART", para garantir a integridade referencial da tabela de fatos em sua chave estrangeira ID_TMPO. Este campo deve referenciar (via Foreign Key) o mesmo campo da dimensão analítica.

Os passos seguintes desta etapa de modelagem física do banco, como descrito no Capítulo 2, são a criação da instância no SGBD, o modelo de indexação de dados, questões de segurança, de auditoria, de acesso e, por fim, a criação da base física. As etapas de segurança e auditoria têm características de desenvolvimento muito particulares em cada empresa e o projeto deve obrigatoriamente se adequar a toda burocracia interna. Adicionalmente, uma estrutura de segurança e controle de acesso pode ser desenvolvida, mas este é um ponto de cuidado pois implementar um ambiente com uma segurança perfeita é algo muito difícil e que pode tomar muito tempo, e esta tarefa não deve gerar um problema no cronograma do projeto.

Definidos os modelos lógico e físico que serão utilizados na iteração, os desenvolvedores podem se concentrar no processo de carga das tabelas, que deve estar centrado em questões como bom desempenho e alta qualidade dos dados processados. Cada tabela deve ser tratada separadamente e deve haver um alto rigor na análise e validação dos arquivos fontes antes de se iniciar o processamento, pois o custo de um erro identificado no início do processo é muito menor do que quando ele é identificado nas etapas finais.

Ao longo do desenvolvimento, manter um documento de mapeamento de fontes é importante. Inicialmente incompleto, ele vai sendo preenchido conforme o conhecimento dos analistas sobre as 
fontes evolui, documentando o processo de uma maneira técnica e informativa a todos na equipe, envolvidos ou não com o desenvolvimento de cada módulo. É esperado portanto que este documento sofra constantes evoluções ao longo da iteração, podendo inicialmente descrever o conhecimento mais básico do que deve ser implementado, evoluindo junto com o projeto para uma documentação campo a campo do que foi implementado no processo ETL. A Figura 5.3 traz um exemplo de um mapeamento de fontes para a tabela de fatos desta 1a iteração.

\begin{tabular}{|c|c|c|c|c|c|}
\hline $\begin{array}{l}\text { Database Destino: } \\
\text { Tabela Destino: } \\
\text { Processo ETL: }\end{array}$ & \multicolumn{2}{|c|}{$\begin{array}{l}\text { D_DWCTLM } \\
\text { TB_FAT_MVTO_CART } \\
\text { SEQ_ETLFATS }\end{array}$} & & & \\
\hline \begin{tabular}{|l} 
Tabela \\
Origem
\end{tabular} & \begin{tabular}{|l} 
Campo \\
Origem
\end{tabular} & \begin{tabular}{|l|} 
Tabela \\
Destino \\
\end{tabular} & \begin{tabular}{|l|} 
Campo \\
Destino \\
\end{tabular} & \begin{tabular}{|l|} 
Transformação \\
Descrição
\end{tabular} & \begin{tabular}{|l|} 
Comentários \\
Relevantes \\
\end{tabular} \\
\hline TABMVTCART & MVTDATE & TB_FAT_MVTO_CART & ID_TMPO & GROUP BY & Chave da tabela \\
\hline TABMVTCART & MVTPROD & TB FAT MVTO CART & ID PRDT & GROUP BY & Chave da tabela \\
\hline & & TB_FAT_MVTO_CART & QT_MVTO & COUNT (DISTINCT) & \\
\hline TABMVTCART & MVTMTFIN & TB_FAT_MVTO_CART & MT_MVTO & SUM (MVTMTFIN ) & \\
\hline
\end{tabular}

Figura 5.3: Mapeamento de fontes para a tabela de fatos

A preocupação dos desenvolvedores com o processo de ETL deve existir para a carga de cada tabela do modelo, individualmente. A dimensão tempo foi a primeira a ser desenvolvida por ser uma dimensão especial e simples, além de sua carga ser realizada uma única vez. Ela deve ter um histórico pelo menos equivalente ao do ambiente transacional, mas que tenha também um bom período de tempo futuro. Abaixo segue a procedure oracle que foi desenvolvida para popular a dimensão tempo. Ela recebe dois parâmetros inteiros, referentes ao número de anos que a dimensão deve ser populada para o passado e para o futuro.

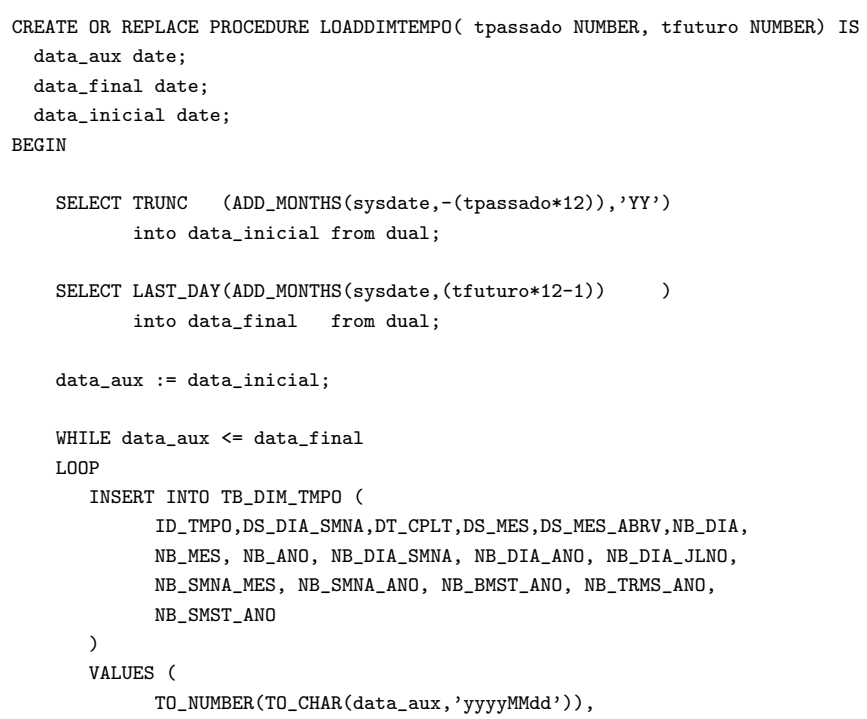




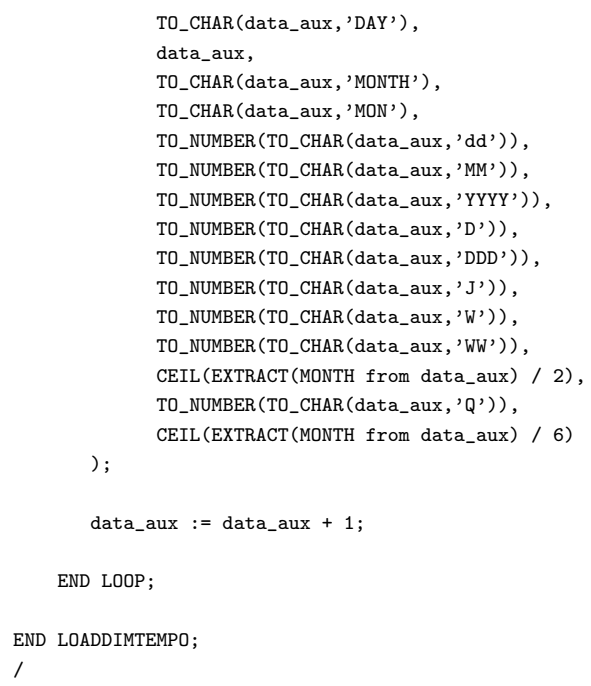

E após sua criação, uma carga com nove anos de histórico passado e 22 anos de dados futuros foi executada e a tabela de tempo ficou inteiramente preenchida desde o primeiro dia do ano 2000 até o último dia do ano 2030, em uma carga que levou menos de 10 segundos para ser finalizada e que gerou pouco mais de 11 mil registros na dimensão.

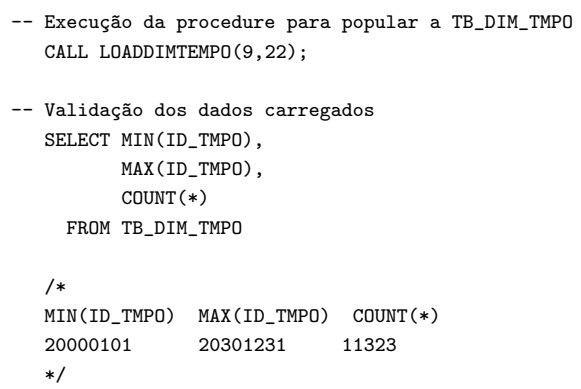

A etapa seguinte na implementação do processo ETL é a carga da tabela de fatos de movimento cartão. Nesta primeira etapa, a extração dos dados limpos e validados dos arquivos transacionais alimenta o processamento para realização de alguns cálculos, como uma contagem e também a soma dos montantes transacionados no dia, conforme mostrado na figura 5.4. O arquivo criado no final do processo, chamado TO_LOAD_FATO, é utilizado para fazer a carga da tabela de fatos, diretamente no banco. Este arquivo possui em seus registros uma coluna com a chave da dimensão de data e outras duas colunas com as duas métricas calculadas, e já está pronto para carregar a tabela de fatos.

Uma questão interessante sobre esta primeira iteração é que não foi realizado nenhum lookup para obter a chave relativa à dimensão de tempo, como mostrado no Capítulo 2, na Figura 2.5. 


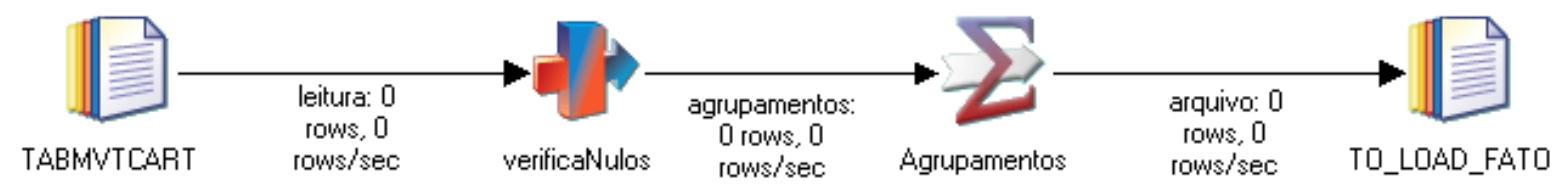

Figura 5.4: Job que realiza a agregação dos dados transacionais

O ponto aqui é que a chave da dimensão especial de tempo é um número, mas não um número seqüencial como em outras dimensões. A chave da dimensão tempo é um inteiro composto pela concatenação dos valores ANO, MÊS e DIA e o uso desta chave oferece vantagens para a dimensão tempo em relação a chaves seqüenciais de outras dimensões. Uma delas é a não necessidade de realizar lookups, pois o campo transacional que traz a data pode ser transformado em um inteiro no formato desejado e carregado na tabela de fatos. Outra vantagem é que a tabela de fatos pode ser particionada diretamente pela data, permitindo um considerável aumento no desempenhos em consultas que tenham filtros de tempo [38], além de ser uma forma mais lógica e que atende às exigências de chaves inteiras da modelagem dimensional.

Um sequenciador também foi criado para os jobs de carga da tabela de fatos como mostrado na figura 5.5, que recebe como parâmetros a data do arquivo a ser processado. Com esta estrutura, uma rotina simples que chame este processo diversas vezes seqüencialmente, com datas crescentes, pode realizar uma recuperação de histórico automatizada, o que facilita a geração de relatórios históricos com as poucas métricas desenvolvidas até este ponto.

Um assunto que não foi discutido nesta seção foram os testes de desenvolvimento, o que não significa que eles não foram realizados. Os testes sobre arquivos transacionais utilizados neste processo são feitos por uma ferramenta proprietária da empresa (como descrito na Seção 5.2.3), que aplica regras de controle de qualidade nos arquivos transacionais assim que eles são disponibilizados, lançando alertas ou erros em caso de problemas com os arquivos e permitindo que uma ação seja tomada antes do início da carga. Nas próximas iterações, outros testes são inseridos no processo.

Diversas outras características, da Seção 2.4, foram também satisfeitas no processo desenvolvido na ferramenta de ETL, como confiabilidade, gerenciabilidade, recuperação de falhas, controle de fluxo, processamento paralelo, gerenciamento de repositório, gerenciamento da segurança, etc. Há outros que não foram implementados, por questões de tempo, dificuldade técnica ou pela menor prioridade em relação às demais, mas nada impede que sejam implementadas em alguma próxima iteração. Serão apresentados agora os passos da trilha de BI, que tem a importante responsabilidade de apresentar os dados para os usuários, em uma interface limpa e amigável. 


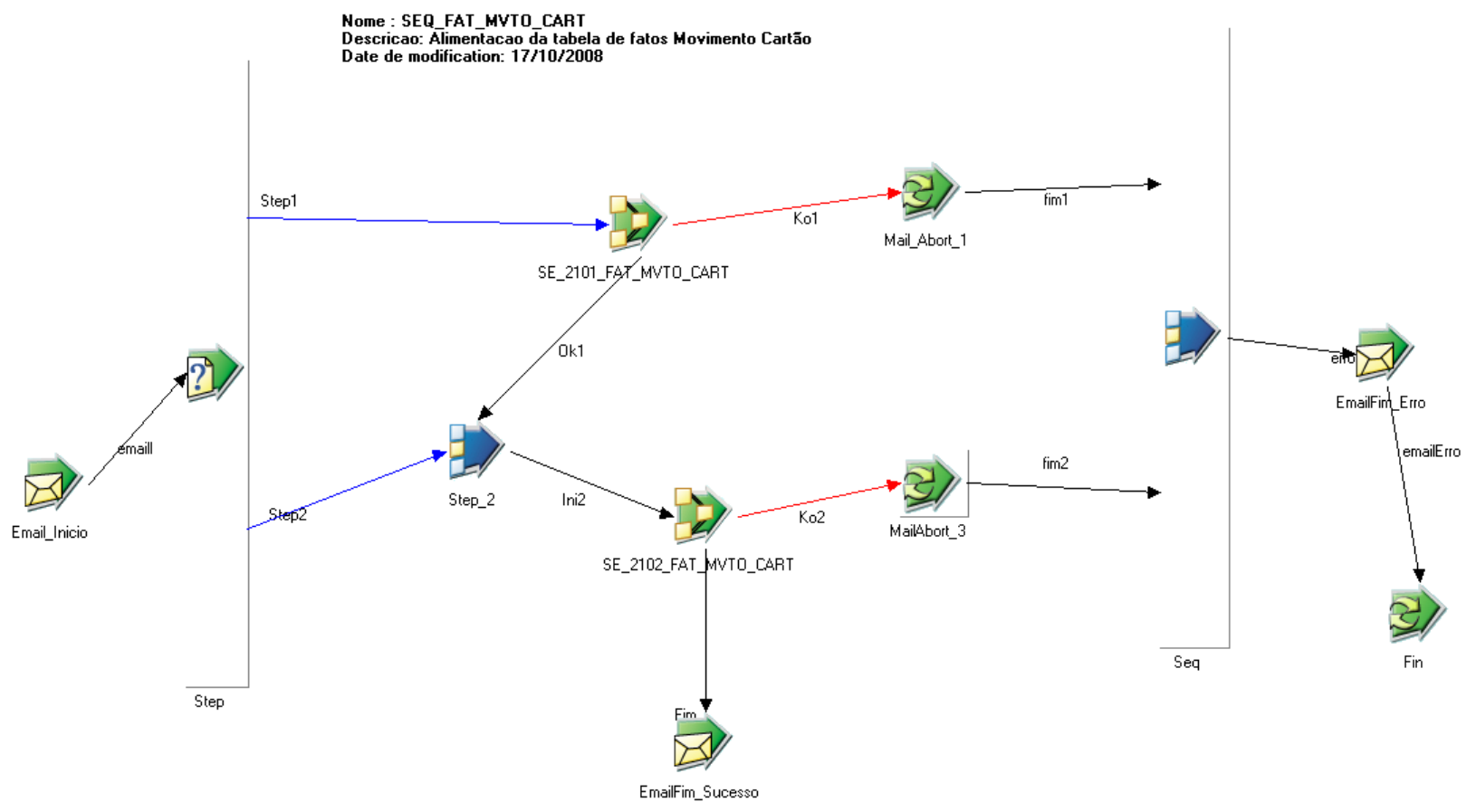

Figura 5.5: Sequenciador dos jobs da tabela de fatos

\subsubsection{Trilha das aplicações de BI}

As duas principais dependências da trilha de aplicações de BI são: a escolha da ferramenta (feita na trilha da tecnologia) e o desenvolvimento do modelo dimensional (feito na trilha dos dados). Quando estes dois pré-requisitos estiverem satisfeitos, o desenvolvimento pode ser iniciado mas, enquanto isso, alguns "rascunhos" de relatórios de apresentação podem ser planejados, dando uma melhor visualização do que poderá ser implementado. Esta tarefa é possível pois a especificação de requisitos, apresentada na Tabela 5.1 prevê no item de requisitos funcionais e não funcionais alguns exemplos dos relatórios em uso pelos clientes e, no item fontes de dados deste mesmo documento, é possível saber quais dados serão tratados na iteração, facilitando o desenho de alguns rascunhos de relatórios.

A definição do modelo de dados desta 1a iteração, na Seção 5.2.4, definiu a criação de uma dimensão e de uma tabela de fatos e, para ferramenta de BI, foi escolhido o Microstrategy, muito eficiente na geração de relatórios e com uma alta capacidade na manipulação OLAP. Iniciado o projeto dos relatórios, como descrito na Seção 2.5.1, foi realizada uma validação dos "rascunhos" feitos anteriormente, documentando como deveria ser feita a implementação de cada relatório, com mapeamento dos campos, regras de negócio, as hierarquias dos atributos e, por fim, os tipos de interações que os usuários poderiam ter com cada um. 
$\mathrm{Na}$ fase de implementação, foram desenvolvidos os metadados da ferramenta. Este trabalho foi fazer um mapeamento lógico dos campos e das tabelas do banco de dados para a ferramenta de BI, criando objetos do tipo atributos (para campos de dimensões) e fatos (para campos da tabela de fatos). A partir dos fatos foram definidas objetos do tipo métricas que, juntamente com os atributos, possibilitam a criação dos relatórios analíticos. Uma boa vantagem deste método de trabalho é a contínua reutilização dos objetos já mapeados, característica que também torna simples o desenvolvimento de novos relatórios. A fase de integração mostra alguns dos relatórios desenvolvidos nesta etapa.

\subsubsection{Integração e implantação}

A etapa de integração é responsável por garantir que tudo o que foi desenvolvido anteriormente esteja sincronizado e funcionando em conjunto e, para isso, o processo deve ser inteiramente testado, em um ambiente de homologação que possa ter seu estado restaurado quando necessário. Ao final da homologação, vem a fase de implantação e, por isso, é importante ter um conjunto de scripts funcionais que possam ser simplesmente executados no ambiente de produção para implantar os desenvolvimentos da iteração.

A seqüência de validações da fase de integração, descrita na Seção 2.6, é composta por uma bateria de testes sobre as partes mais globais do processo e sobre o sistema completo, integrado. A fase de validações dos scripts descrita no parágrafo anterior é chamada neste texto de testes de implantação. Para validar o ambiente, a primeira atividade foi criar um procedimento de testes comum, com as quatro etapas descritas no primeiro item da Seção 2.6 para que o mesmo procedimento pudesse ser utilizado nas diversas validações, tanto de operações do processo quanto para qualidade e desempenho global.

Validar a trilha de tecnologia foi uma tarefa relativamente simples, pois as duas outras frentes paralelas de desenvolvimento (da trilha dos dados e de aplicações de BI) foram responsáveis por testar se as ferramentas funcionavam e se estavam bem configuradas e somente foi necessário validar pontos não-funcionais, como o desempenho, facilidade de aprendizado e de uso, segurança, etc. Nenhum destes pontos apresentou problemas.

Para a trilha dos dados, a técnica usada na primeira iteração foi de aplicar as evoluções no banco e realizar uma seqüência de várias cargas na nova estrutura, ação que permitiu corrigir pequenos problemas de sincronismo nos passos do processo. Foi importante a capacidade de fazer o ambiente voltar ao seu estado anterior para reexecução de todos os passos e garantia de que os scripts estavam corretos e poderiam ser executados em produção. Além disso, os dados das tabelas após a carga também foram verificados para garantir sua qualidade e correção.

A trilha de ferramentas de BI é também um complemento à validação realizada no processo de 
ETL, pois os dados resultantes da carga são utilizados na geração dos relatórios. A Figura 5.6 exibe uma visualização gráfica de dois relatórios esperados para esta iteração.
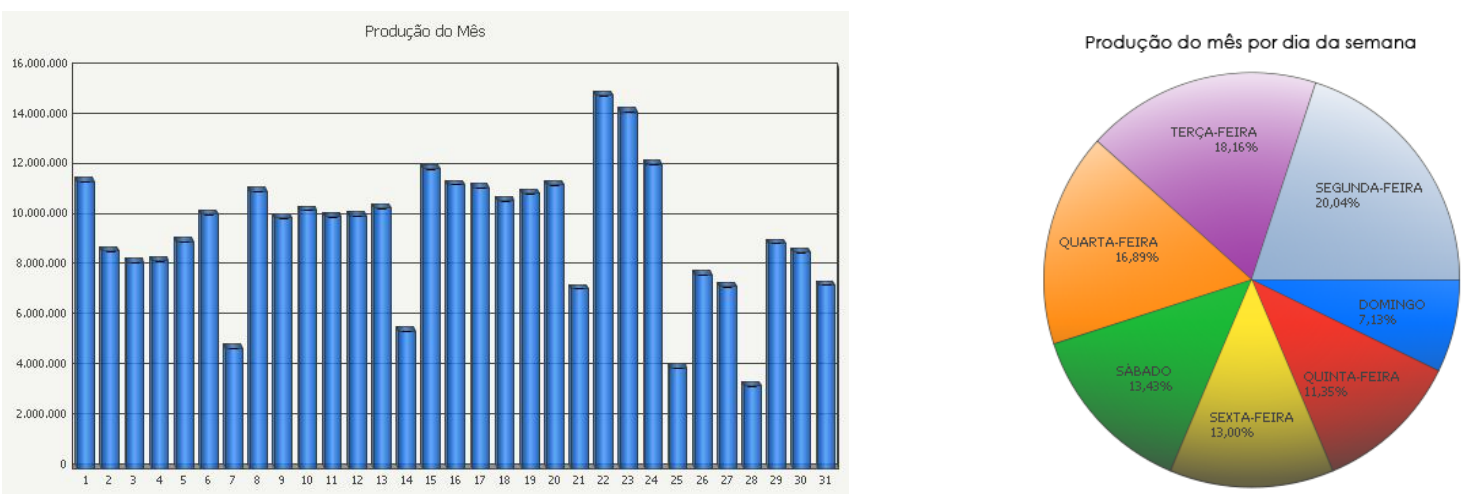

Figura 5.6: Exemplo de dois relatórios implementados nesta iteração

Por fim, foi necessário analisar os requisitos de sistema para acessar o ambiente analítico e garantir que o ambiente dos usuários tinha as características necessárias para utilização das ferramentas. De uma forma geral, a validação do processo de BI não apresentou grandes problemas, nem os dados carregados pelo processo de ETL, utilizados na geração dos relatórios e, assim, a fase de integração foi completada com sucesso.

A implantação foi realizada com a execução dos scripts de migração para o ambiente de produção, seguida por algumas validações do ambiente. Este trabalho foi facilitado por ser a primeira iteração, o que não exigiu cuidados com os dados já carregados no DW, que estava vazio.

\subsubsection{Manutenção}

A estrutura clássica de manutenção do projeto de DW, descrita na Seção 2.7, consiste basicamente em oferecer suporte e treinamento para os usuários e fazer uma boa monitoração do ambiente (tanto no back-room quanto no front-room). O suporte e o treinamento foram realizados para os usuários que teriam acesso ao ambiente, poucos no começo, e a estrutura de suporte foi simples devido a esta pequena quantidade de usuários. O monitoramento foi uma tarefa contínua para acesso a relatórios e também para o processo de carga, executado todos os dias no período da madrugada, para que os dados atualizados estejam sempre disponíveis pela manhã.

\subsubsection{Crescimento}

Para passar à próxima fase, o gerente do projeto deve analisar as fases trabalhadas na iteração e medir a eficiência em cada uma das etapas, utilizando métricas que possam ser usadas para aprimo- 
rar as etapas futuras. Trabalhos como o do Danilo Sato [47] podem ajudar muito na escolha destas métricas, que podem variar de acordo com o gerente e também com o projeto.

\subsubsection{Gerenciamento}

Pela aplicação de práticas ágeis, a fase de gerenciamento precisa sofrer algumas adaptações em relação ao processo descrito na Seção 2.9, pois existe a necessidade de um constantemente direcionamento global para as funcionalidades da versão do trimestre. Cada iteração pode ser entregue para os usuários, que têm acesso as estas funcionalidades parciais, mas é no final do ciclo trimestral que o projeto estará na versão que foi acordada com o cliente, em um conjunto de dados que trará maiores benefícios à empresa.

Desta forma, caso a próxima iteração esteja dentro do mesmo ciclo trimestral, que é o caso, a tarefa do gerenciamento é direcionar o planejamento para que seu escopo esteja adequado à versão do trimestre ou, caso tenham sido encontrados problemas mais sérios, negociar com o cliente uma redução no escopo do ciclo trimestral, também uma característica de métodos ágeis (ver Tabela 4.2). Caso o ciclo trimestral tenha terminado, uma nova versão deve ser planejada para o próximo ciclo, mantendo a contínua evolução do DW e fazendo com que novas funcionalidades e novas capacidades analíticas estejam continuamente sendo desenvolvidas. Será agora iniciada a descrição dos passos realizados na segunda iteração deste exemplo de aplicação.

\subsection{A 2a iteração}

Aqui se inicia mais um ciclo do DW evolutivo que já conta com uma versão mínima implantada em produção e disponível aos usuários. A equipe pode iniciar a segunda fase de trabalho, dentro do assunto do ciclo do trimestre, para aumentar a quantidade de campos e, conseqüentemente, o número de funcionalidades do DW.

\subsubsection{Planejamento}

$\mathrm{Na}$ iteração anterior foi feito um rascunho do planejamento desta etapa e, como não ocorreram imprevistos ou problemas, o plano pôde ser seguido, direcionando o trabalho para as funcionalidades que faltam na versão do trimestre. O ambiente já foi estruturado e está com as ferramentas necessárias ao desenvolvimento e, por hora, nenhum acréscimo na infra-estrutura se faz necessário. 


\subsubsection{Especificação de requisitos}

O mesmo documento apresentado na figura 5.1 pode ser utilizado, adicionando uma seção nomeada "2a Iteração" com as características específicas desta iteração, como os requisitos funcionais e não funcionais e também as novas fontes de dados. Esta estrutura é adequada por centralizar o histórico de requisitos do ciclo trimestral em um único documento, permitindo visualizar com clareza qual iteração foi responsável por quais desenvolvimentos.

\subsubsection{Trilha da tecnologia}

A trilha da tecnologia não sofreu alterações, pois a infra estrutura tecnológica mínima que foi montada ainda tem baixa utilização, já que poucos recursos são utilizados nas primeiras iterações de desenvolvimento. Por exemplo, a necessidade de disco da iteração anterior pode ter sido de 1 Giga, o menor disco à venda poderia ser de 16 Gigas e o melhor custo benefício poderia ser um disco de 32 Gigas. Em qualquer dos dois últimos casos, a capacidade instalada teria sido bastante superior à necessidade da iteração, e não há necessidade de evoluir esta estrutura imediatamente.

\subsubsection{Trilha dos dados}

Novamente, a trilha dos dados se inicia pelo desenvolvimento do modelo lógico e, nesta segunda iteração, foi definida a adição da dimensão Produto no modelo, para que os montantes e contadores possam ser visualizados em um nível de maior detalhamento. Nesta dimensão, mostrada no modelo lógico da Figura 5.7, quatro novos campos estão presentes no modelo dimensional, sendo uma chave numérica, o código transacional e dois campos descritivos para o produto. Também foi adicionada na tabela de fatos uma chave estrangeira para referenciar a nova dimensão.

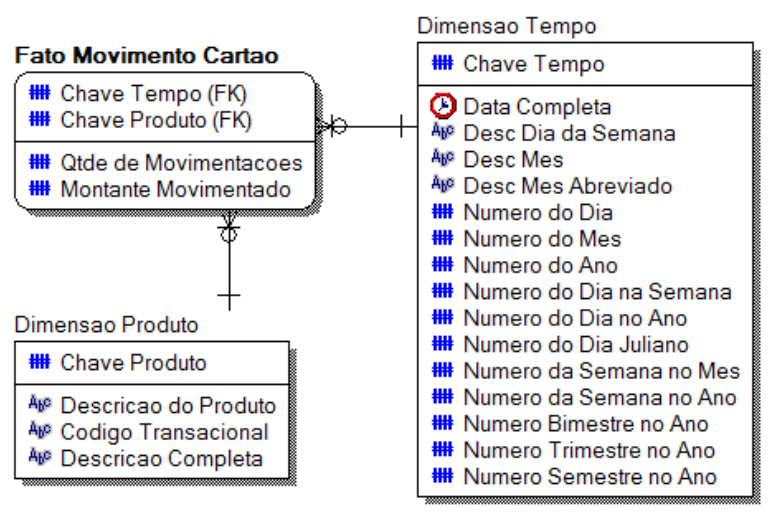

Figura 5.7: Modelo lógico da 2a iteração

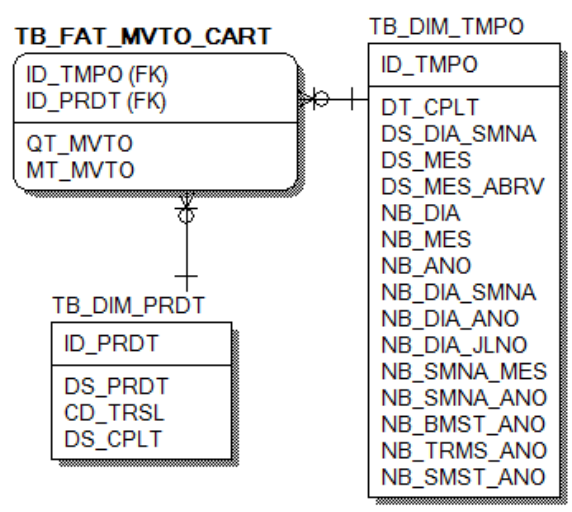

Figura 5.8: Modelo físico da 2a iteração

A definição do modelo físico foi feita em seguida e, seguindo o padrão de nomenclatura do modelo, foi definida a tabela da Figura 5.8. O controle escolhido para mudanças lentas nesta tabela é o tipo 
1 do SCD, descrito na Seção 2.4.1. Um tratamento SCD não foi necessário para a dimensão de data, na iteração anterior, pois se trata de uma dimensão especial.

A descrição das evoluções aplicadas nesta iteração são descritas a seguir.

- Adicionar tabela: esta transformação foi aplicada apenas na tabela "TB_DIM_PRDT".

- Adicionar coluna: aplicada em todos os campos da nova tabela "TB_DIM_PRDT" e também na nova chave estrangeira da tabela de fatos "TB_FAT_MVTO_CART".

- Adicionar índice: aplicada individualmente em cada campo chave das duas tabelas, que é o campo ID_PRDT das tabelas "TB_FAT_MVTO_CART" e "TB_DIM_PRDT".

- Adicionar chave estrangeira: aplicada na "TB_FAT_MVTO_CART", para garantir a integridade referencial da tabela de fatos em sua nova chave estrangeira ID_PRDT.

Após aplicação das evoluções de banco descritas acima, o processo de carga da nova tabela precisa ser desenvolvido. Inicialmente, a maior preocupação aqui é que, ao longo das cargas diárias do DW, quando um novo produto aparecer no ambiente, a dimensão seja preenchida antes da carga na tabela de fatos, para manutenção da integridade referencial do banco. A Figura 5.9 mostra o job da ferramenta de ETL que implementa o SCD tipo 1, como descrito na Seção 2.4.1.

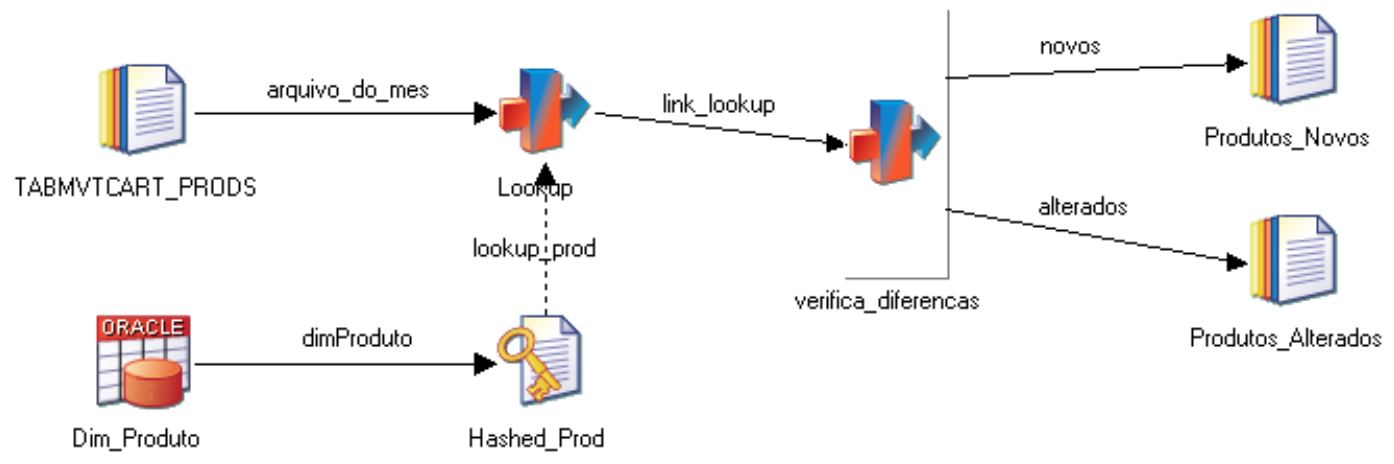

Figura 5.9: SCD para a dimensão de produtos

Inicialmente a única verificação realizada nos campos desta tabela é quanto ao nome do produto que, quando tiver sido alterado, é salvo no arquivo "Produtos_Alterados", que é fonte para uma atualização dos registros na dimensão produto, conforme descrito no SCD tipo 1.

Ao contrário da dimensão de tempo, a dimensão produto precisa obter uma chave numérica seqüencial (surrogate key) para utilização interna no processo. Por isso, todos os produtos precisam obter um identificador numérico único antes de serem inseridos na dimensão, e esta tarefa é mostrada no job da Figura 5.10. 


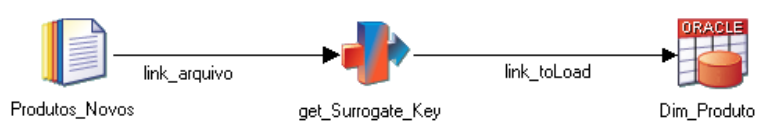

Figura 5.10: SCD para a dimensão de produtos

O tratamento dos arquivos garante um controle de qualidade eficaz, e a inserção de uma nova dimensão deve sempre levantar esta questão, analisando os campos que podem e os campos que devem ter controles de qualidade automáticos associados a eles, antes do processamento ETL.

\subsubsection{Trilha das aplicações de BI}

A adição da dimensão produto alterou o nível de detalhamento da tabela de fatos, mas não invalidou os relatórios já existentes pois, como mostrado na Seção 4.5, as consultas agregadas não sofrem com este tipo de evolução do modelo dimensional. No entanto, a nova tabela possibilita a criação de novos relatórios, que ofereçam uma visão dos dados que não era possível: por produtos.

Assim, foi implementado na ferramenta de BI o metadados da nova dimensão, sem necessidade de alterar o metadados já existente das outras tabelas, desenvolvidas na iteração anterior. Os novos relatórios especificados foram implementados e testados localmente, e a fase de integração permite visualizar estes relatórios funcionando com os dados processados na trilha de dados.

\subsubsection{Integração e implantação}

A integração dos dados possibilita uma visualização abrangente do que foi implementado nas diferentes etapas trabalhadas neste ciclo. Uma boa validação deve ser feita, principalmente na trilha de dados, responsável pelas maiores alterações desta segunda iteração juntamente com a trilha de BI, pois novos relatórios foram desenvolvidos e apenas testes locais validaram os desenvolvimentos.

A aplicação de testes nas tabelas carregadas pelo processo de ETL pode ser feita de diversas maneiras. Por exemplo, ao fazer uma carga de um período de 3 meses em homologação, os registros podem ser comparados com este mesmo período no ambiente de produção, ainda não alterado. Outra opção bastante simples é executar e comparar os relatórios da primeira iteração com os dados carregados na segunda iteração, e eles devem estar idênticos aos do ambiente de produção.

Nesta segunda iteração os relatórios desenvolvidos trouxeram uma maior riqueza de informações com a inclusão da dimensão de produtos. A Figura 5.11 mostra dois relatórios novos que utilizam estas novas informações, e que também puderam ser utilizados na validação dos dados carregados pelo processo ETL. 

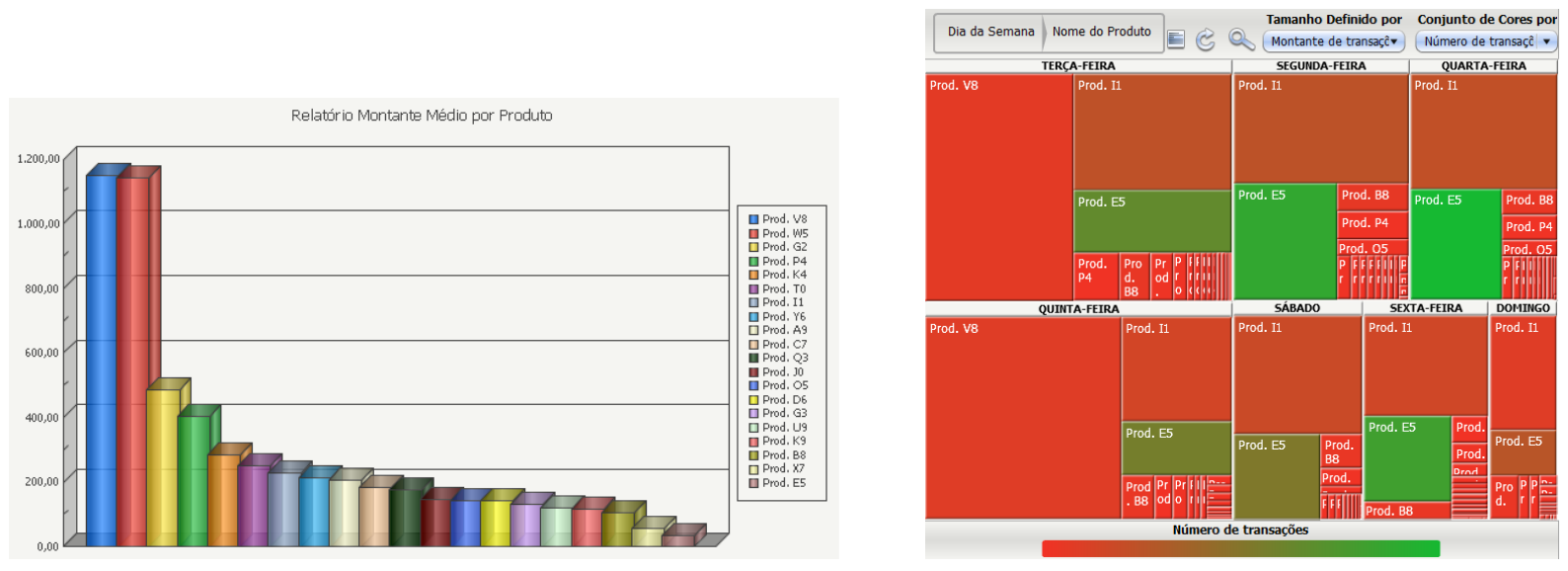

Figura 5.11: Dois novos relatórios implementados na segunda iteração

Um exemplo da maior capacidade analítica existente na ferramenta de BI é dado na Figura 5.11, que traz dois gráficos: o primeiro é um tradicional gráfico de barras, que mostra a produção no mês por produto e, o segundo, que é um mapa de calor [19]. Neste último tipo de relatório, desconhecido de muitos, duas métricas devem ser definidas: uma para o tamanho do quadrado e outra para a intensidade da cor. Definidas estas métricas, a ferramenta de BI faz um posicionamento automático dos quadrados, de forma que os maiores (mais relevantes) estejam sempre à esquerda superior de suas subcategorias, deixando os quadrados menos relevantes à direita inferior. No exemplo, produtos com produção muito baixa são representados por quadrados pequenos que ficam praticamente ocultos (por terem pouca relevância), à direita inferior enquanto montantes altos ficam bem visíveis à esquerda superior.

\subsubsection{Manutenção}

A manutenção do projeto sofre pouca alteração, apenas com a adição de alguns materiais de suporte e treinamento para as novas capacidades implementadas nessa iteração. O monitoramento continua sendo feito para garantir que não haja degradação do ambiente de ETL, caso em que um alerta deve ser lançado para que as equipes façam uma intervenção preventiva no ambiente, se antecipando ao problema.

\subsubsection{Crescimento}

Analogamente à fase anterior, o gerente de projeto deve fazer uma análise comparativa da eficiência da equipe nesta iteração do trabalho, buscando otimizar sua produtividade. 


\subsubsection{Gerenciamento}

O direcionamento para atingir as metas estabelecidas na versão do trimestre precisa ser constantemente analisado para que o trabalho da equipe esteja corretamente direcionado. Se houverem atrasos ou problemas que possam atrapalhar este objetivo, o gerenciamento do projeto deve buscar a solução, seja transferindo para a equipe de planejamento os problemas identificados ou negociando um escopo reduzido com o cliente.

\subsection{A 3a iteração}

Esta é a última iteração do ciclo trimestral e, após seu término, a versão funcional que foi acordada com o cliente deverá ser disponibilizada para uso no ambiente de produção. Por isso, esta fase é de extrema importância, pois é a iteração que conclui todo o trabalho dos ciclos anteriores e faz as validações finais para entrega da versão do trimestre.

\subsubsection{Planejamento}

Todas as funcionalidades definidas no planejamento da 1a iteração (com a técnica de priorização RFV) devem estar disponíveis ao final desta iteração e, por isso, o que não tiver sido implementado ainda deve fazer parte do escopo. Se algum problema tivesse ocorrido em iterações anteriores, a ponto de impedir que a entrega da versão do trimestre fosse realizada no prazo, uma negociação com o cliente teria sido feita, o que não foi necessário pois o andamento do trabalho está dentro do esperado.

\subsubsection{Especificação de requisitos}

O mesmo documento apresentado da Figura 5.1 pode ser utilizado, mas adicionando as novas informações em uma seção nomeada "3a Iteração", com as características específicas da iteração.

\subsubsection{Trilha da tecnologia}

Novamente, não há alterações no ambiente tecnológico para esta iteração, e nada precisa ser feito. No entanto, é importante garantir que a estrutura tecnológica esteja dentro de sua capacidade. Caso algum recurso de hardware ou software esteja com utilização excessiva, a equipe de manutenção, responsável pelo monitoramento do ambiente, deve comunicar o problema. 


\subsubsection{Trilha dos dados}

A trilha dos dados começa pelo modelo lógico e para atender aos requisitos da iteração, uma nova dimensão é inserida, como mostrado na Figura 5.12, onde a nova dimensão cartão possui quatro atributos e uma chave numérica. Além da nova dimensão também são realizadas outras pequenas alterações no modelo, como a inserção de um campo na tabela de fatos, referente à data da compra anterior ao registro atual (fato anterior), o que possibilita identificar rapidamente o intervalo entre as compras de um determinado cartão.

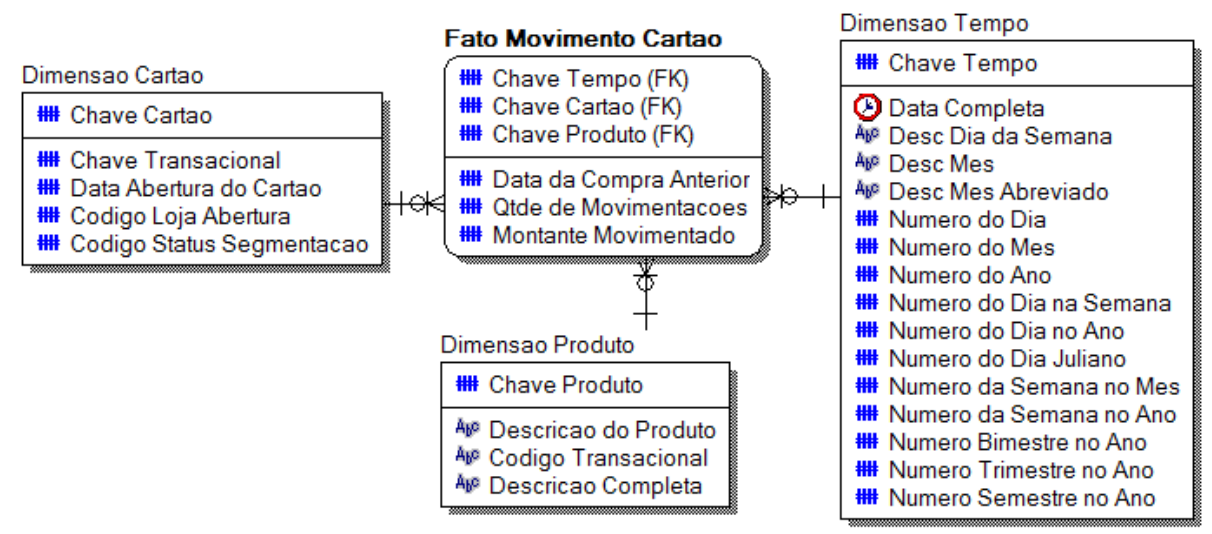

Figura 5.12: Modelo lógico da 3a iteração

Depois do modelo lógico, o modelo físico foi desenvolvido para definir a melhor estrutura de dados para representar o modelo lógico da Figura 5.12. O modelo físico traz algumas novidades em relação aos casos anteriores, com campos da dimensão cartão que estão presentes somente no modelo físico e não aparecem no modelo lógico, que são os campos "DT_INI_VLDE" e "DT_FIM_VLDE". Estes campos são necessários pois o controle de crescimento desta dimensão precisa ser histórico e, por isso, foi selecionado o SCD tipo 2. Estes dois campos estão somente no modelo físico pois são campos de controle e não precisam estar presentes no modelo lógico.

Além disso, pode-se notar que foram implementadas quatro views (ou visões) no modelo físico apenas. Estas visões são necessárias porque, em uma estrutura relacional, as consultas acessam e relacionam cada tabela da consulta e, se um filtro for aplicado em uma destas tabelas, ele restringe os registros retornados da tabela.

Ocorre que, na modelagem dimensional, os filtros devem ser realizados nas dimensões e não diretamente nas tabelas de fatos, e a dimensão de tempo pode ser referenciada por quaisquer campos de datas do modelo. Assim, o método de acesso às tabelas em bancos relacionais causaria um problema em situações como esta, quando a mesma tabela de tempo estiver fazendo joins com campos diferentes na mesma consulta. Para resolver isso, deve-se utilizar uma visão para cada campo do tipo 


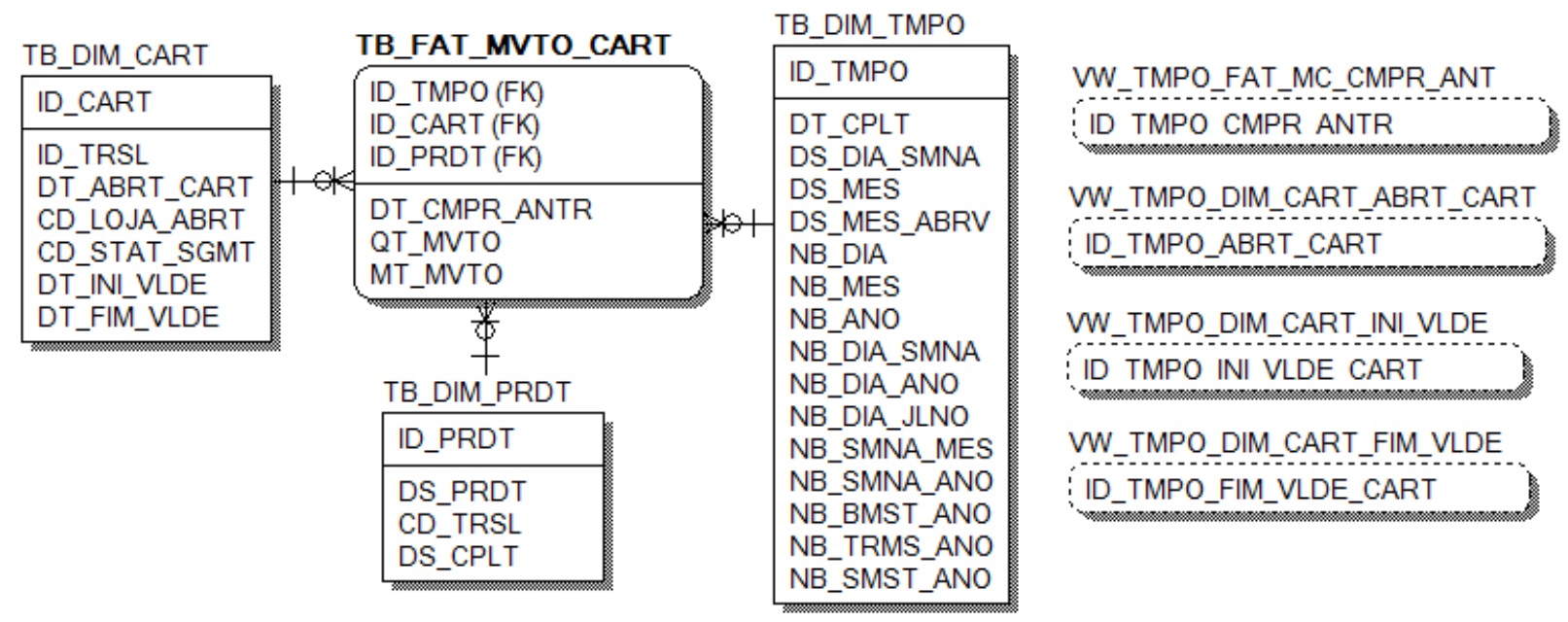

Figura 5.13: Modelo físico da 3a iteração

data, em que cada visão faz referência direta à dimensão de tempo. Uma visão exige muito pouca manutenção, especialmente nesta situação, em que elas apontam para a dimensão de tempo, que é uma dimensão congelada.

- Adicionar tabela: esta transformação foi aplicada à tabela "TB_DIM_CART".

- Adicionar visão: esta transformação foi aplicada às quatro novas visões adicionadas.

- Adicionar coluna: aplicada no campo DT_CMPR_ANTR da tabela "TB_FAT_MVTO_CART" e nos campos da tabela "TB_DIM_CART".

- Adicionar índice: aplicada individualmente no campo ID_CART das tabelas:

$$
\begin{aligned}
& \text { - "TB_FAT_MVTO_CART" } \\
& \text { - "TB_DIM_CART" }
\end{aligned}
$$

- Adicionar chave estrangeira: aplicada na "TB_FAT_MVTO_CART", para garantir a integridade referencial da tabela de fatos em sua nova chave estrangeira ID_CART.

Quanto ao processo ETL, foi preciso desenvolver um novo processo de carga para a dimensão cartão, similar ao apresentado na Figura 5.9 mas, em vez de simplesmente atualizar os registros da dimensão (SCD tipo 1), o processo o historiza na própria tabela quando um cartão sofre alguma alteração (SCD tipo 2), fechando o registro anterior pela data, e abrindo um novo. Estes processos de historização estão descritos na Seção 2.4.1.

Quanto à carga da tabela de fatos, o arquivo "TO_LOAD_FATO" é utilizado no job da Figura 5.14. Este arquivo tem agora um nível de detalhamento muito maior do que tinha na 1a iteração, 
pois a informação está agregada por tempo, por cartão e também por produto. Nesse job, o arquivo traz os valores das chaves transacionais para obter suas chaves numéricas antes de fazer a carga da tabela de fatos. O job da Figura 5.14 faz esta atribuição de chaves, seguindo o conceito descrito por Kimball na Figura 2.5.

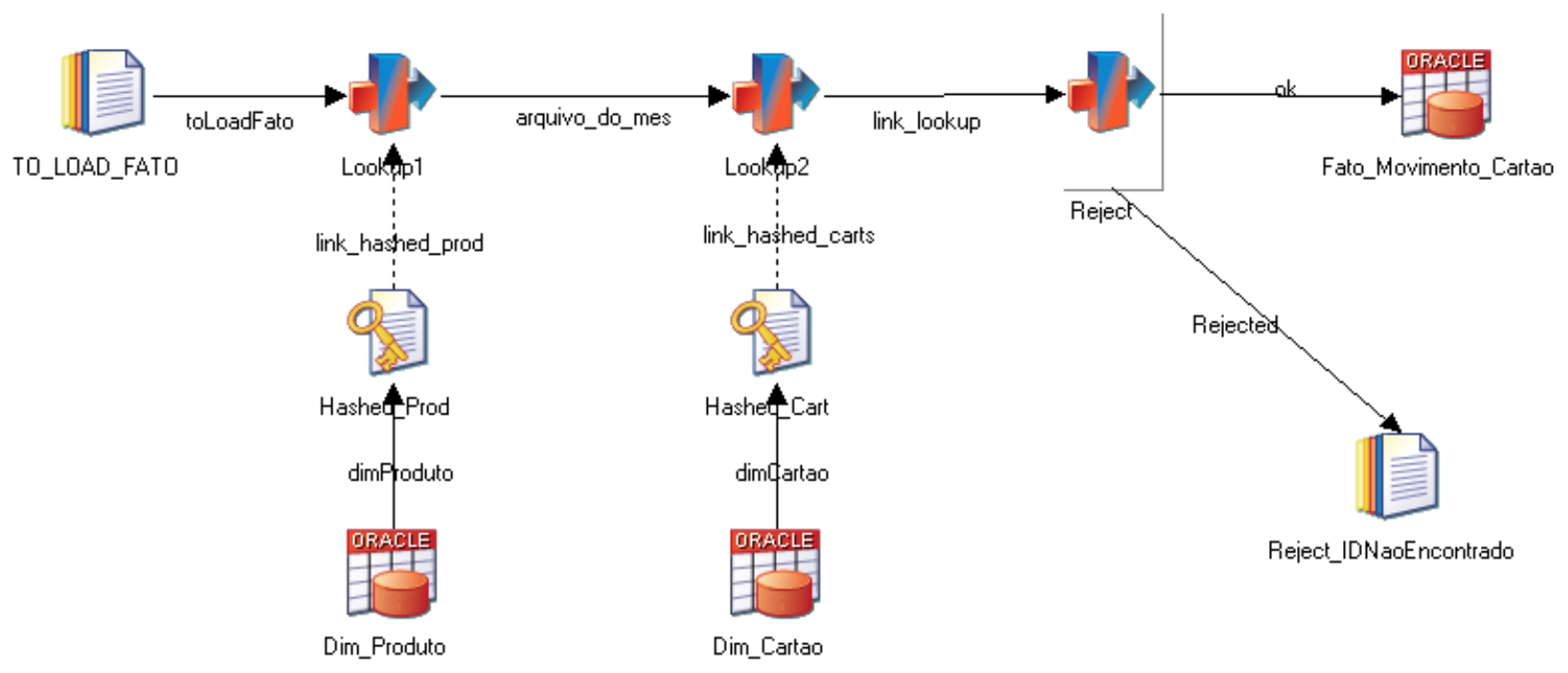

Figura 5.14: Processo de atribuição de chaves antes da carga na tabela de fatos

\subsubsection{Trilha das aplicações de BI}

Os relatórios criados na primeira iteração (Figura 5.6) permitiram uma visualização da informação apenas em uma dimensão: no tempo. Os relatórios da segunda iteração (Figura 5.11) tinham maiores possibilidades analíticas devido ao acréscimo da dimensão de produtos.

A capacidade analítica do DW teve um forte incremento com a adição da dimensão cartão, pelo maior detalhamento das informações. A análise agora está no nível de mais baixo possível e, além de todos os relatórios anteriores estarem válidos, é possível também extrair de um determinado relatório o grupo de cartões que o compõe, ou os melhores cartões dentro de um grupo, etc. Todo o metadados da ferramenta de BI foi adaptado para incluir estas novas capacidades e possibilitar seu uso na geração dos relatórios analíticos.

\subsubsection{Integração e implantação}

Os relatórios das iterações anteriores foram executados com os dados desta iteração, carregados no ambiente de homologação, e eles foram comparados com o ambiente de produção, ainda inalterado. A estabilidade estrutural (Seção 4.5) manteve o funcionamento de toda a estrutura já desenvolvida, e 
os relatórios foram validados. Alguns testes também foram executados, em consultas agregadas para validação de algumas colunas da nova estrutura.

Quanto aos relatórios desenvolvidos nesta última iteração, a integração dos desenvolvimentos também foi validada com a sua execução como por exemplo o relatório da Figura 5.15, que mostra a distribuição de um atributo do cartão chamado "status de segmentação" pelo seu tempo de vida (eixo $\mathrm{x}$ ) e seu gasto médio mensal (eixo y). Todas estas informações podem ser vistas no gráfico da Figura 5.15 , em que cada circulo representa um segmento ${ }^{1}$ e o tamanho do circulo representa a quantidade de indivíduos.

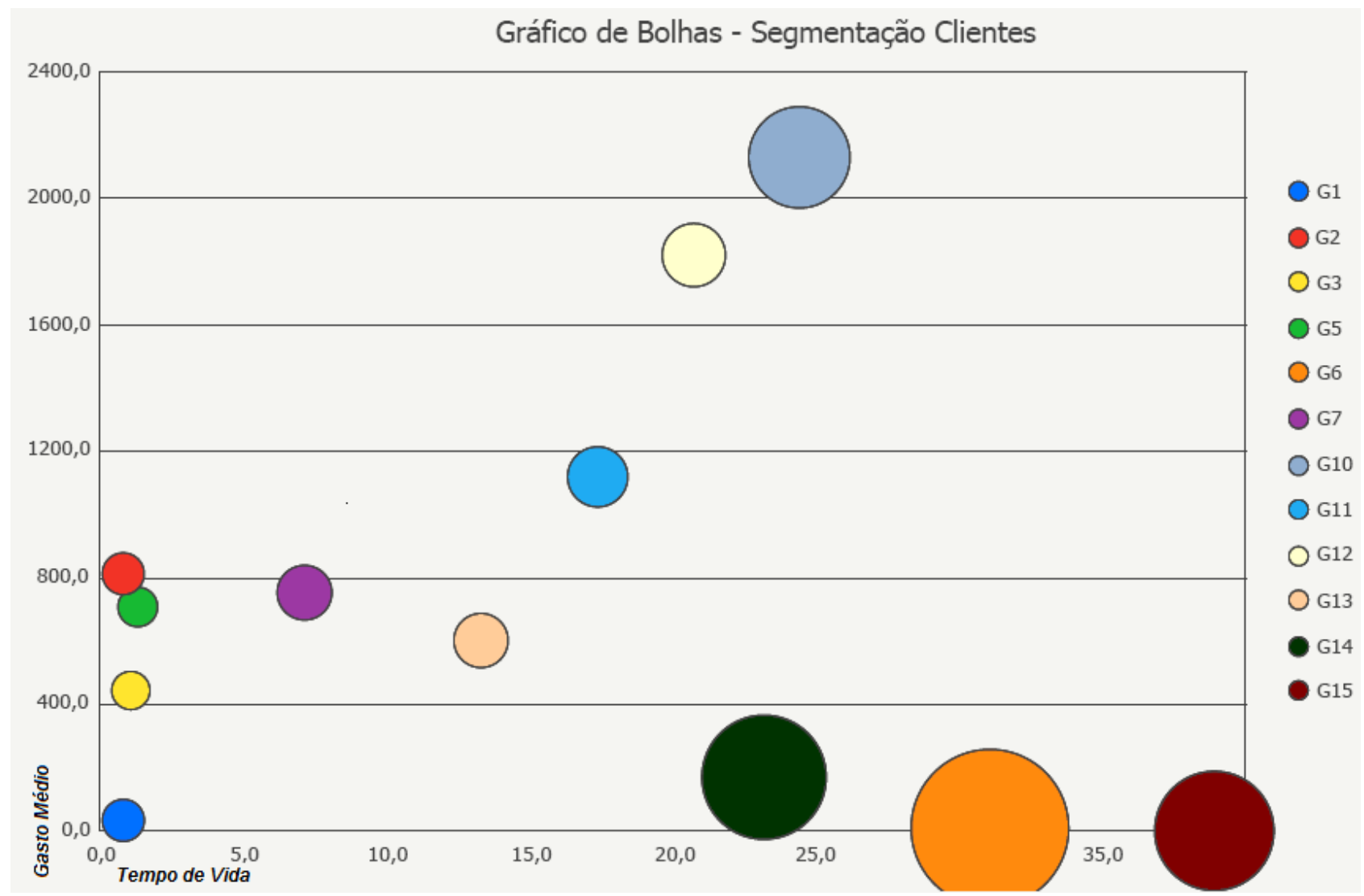

Figura 5.15: Distribuição dos cartões por status de segmento

\subsubsection{Manutenção}

como o nível de detalhamento em que o ambiente se encontra é mais alto, deve haver uma maior atenção das equipes de manutenção, e a monitoração do ambiente deve ser cuidadosa, pois o maior vo-

\footnotetext{
${ }^{1}$ Os segmentos do gráfico foram codificados com valores não contínuos entre G1 e G15 para preservação dos dados da empresa
} 
lume de dados pode causar problemas de infra estrutura, principalmente quanto à utilização de disco.

\subsubsection{Crescimento}

Há ainda muito o que pode ser adicionado nesta estrutura, mas antes de iniciar um novo ciclo, o gerente do projeto deve fazer uma análise global das atividades desenvolvidas e da eficiência da equipe, comparando as métricas de evolução e de desempenho que vêm sendo coletadas ao final de cada iteração, para melhoria do processo.

Quanto à evolução do ambiente analítico, muito ainda pode ser feito. Todos os relatórios desenvolvidos dão um claro exemplo das possibilidade analíticas que podem ser obtidas com iterações curtas de desenvolvimento, e muito ainda pode ser feito para que esta estrutura cresça. Por exemplo a Figura 5.15, que tem o maior nível de detalhamento do exemplo de aplicação, teria potencial analítico ainda maior se permitisse uma visualização por loja do relatório, uma dimensão que ainda não pertence ao modelo de dados mas que pode ser adicionada em uma iteração. Além disso, informações do cliente ligado ao cartão não estão disponíveis e também poderiam trazer maior valor ao modelo analítico. Basta que o cliente escolha e priorize o que é mais relevante ao seu contexto de trabalho e a equipe de desenvolvimento poderá implementar, aumentando ainda mais o valor do DW evolutivo.

\subsubsection{Gerenciamento}

Terminada a versão do trimestre, cabe à fase de gerenciamento estabelecer o novo direcionamento do trabalho no próximo ciclo trimestral. Como o ambiente é muito novo, é natural dar seqüência ao seu crescimento por mais ciclos trimestrais, até que ele tenha uma maior capacidade analítica que o dê uma maior estabilidade.

\subsection{Resumo do Capítulo}

Após uma introdução sobre a empresa, as três iterações apresentadas neste "exemplo de aplicação" ilustraram a mecânica do processo iterativo na construção de um DW evolutivo. Foi possível ver como a utilização de ciclos curtos de desenvolvimento favorecem um desenvolvimento rápido e contínuo, possibilitando entregas freqüentes de funcionalidades aos usuários. Para as diferentes tecnologias, utilizadas em cada etapa do fluxo de engenharia, foram mostrados diversos exemplos de implementações.

O uso de técnicas de bancos evolutivos para evolução do modelo dimensional foi mostrada em cada iteração, mas sem detalhes de implementação (exemplos de códigos estão no Apêndice A). Uma limitação deste exemplo de aplicação é que todos os casos evolutivos apresentados causaram alteração 
no nível de detalhamento da tabela de fatos e, por isso, exigiram às equipes de desenvolvimento reprocessar o histórico da tabela, que é uma tarefa transparente para os usuários do DW.

Esta necessidade de reprocessar o histórico não ocorre em qualquer evolução do modelo, mas apenas diante de alterações que alterem o nível de detalhamento da tabela de fatos. Uma adição ou remoção de coluna de alguma das tabelas do modelo que não altere esta característica não exige reprocessamento do histórico, e duas opções são possíveis em uma situação deste tipo. A primeira consiste em ter o novo campo preenchido a partir de sua entrada no banco e, a segunda, em realizar um reprocessamento de histórico especificamente para o campo, que deve ser a opção escolhida quando forem necessárias análises históricas sobre o campo. 


\section{Capítulo 6}

\section{Conclusão}

O desenvolvimento de um DW evolutivo oferece diversas vantagens a projetos de DW em relação ao seu método tradicional de engenharia. Primeiramente, o tempo de entrega de versões funcionais do banco é muito menor e, por isso, os usuários têm benefícios parciais rapidamente. Em segundo, o processo de desenvolvimento iterativo, que obriga uma seleção constante das funcionalidades prioritárias, ajuda a minimizar o problema de que a equipe gaste tempo e recursos em desenvolvimentos que nunca (ou raramente) serão utilizadas que, como foi visto no Capítulo 4, é um problema comum de projetos muito grandes, que seguem uma especificação inicial completa.

Assim, a contínua seleção de conjuntos reduzidos e priorizados de funcionalidades oferece uma maior garantia de que o tempo e os recursos gastos na sua implementação terão uma melhor relação de custo / benefício, já que o conjunto de funcionalidades pouco utilizadas deverá ser mínima. Para sustentar este crescimento contínuo, as metodologias ágeis têm fundamentos muito fortes e que devem estar presentes no ambiente de trabalho, pois a experiência destes métodos pode ajudar a minimizar os diversos erros que podem ocorrer na implementação de sistemas evolutivos. Além disso, as técnicas de bancos de dados evolutivos têm grande importância para um projeto como este, que é estruturado sobre um banco grande e histórico, e onde se faz necessário grande cuidado com os dados do banco diante de evoluções em seu modelo.

Quanto aos problemas de um projeto de DW evolutivo, o primeiro que pode ser citado é relativo à sua implantação pois, de maneira análoga às dificuldades encontradas pelos métodos ágeis, as pessoas têm uma formação cultural diferente e costumam oferecer resistência para utilizar novas idéias que fujam aos conceitos tradicionais, aos quais todos estão acostumados e que "funcionam". Além disso, a evolução do DW tem um problema adicional, que é relativo ao banco que, após algumas iterações, passa a ter um maior volume de dados, tornando as suas evoluções mais difíceis e demoradas. Esta dificuldade realmente existe, mas não é crítica a ponto de impedir o desenvolvimento evolutivo do DW e, evoluções que necessitam de recuperação de histórico podem ser tratadas em separado nos casos em que o volume das tabelas já esteja grande. 
Além disso, a velocidade evolutiva de um determinado modelo dimensional tende a se desacelerar, pois o número de métricas da tabela de fatos e a quantidade de dimensões associadas a ela é limitada às necessidades analíticas do modelo. Ou seja, uma tabela de fatos e seu modelo dimensional não crescem na mesma velocidade para sempre e, a partir de algum momento, um novo assunto será iniciado, com outra tabela de fatos, que novamente deverá passar por um processo evolutivo mais intenso até atingir uma maior estabilidade. Uma última dificuldade que pode ser citada no desenvolvimento de um DW evolutivo é referente à escolha do conjunto mínimo de dados, que deve trazer o maior valor possível ao DW. A técnica de seleção descrita no trabalho foi baseada em uma técnica de segmentação, o RFV (Seção 4.2), mas é importante ressaltar a dificuldade que há neste processo de seleção dos campos mais importantes no projeto, pois é aqui que se define o escopo de trabalho de um ciclo trimestral de desenvolvimento.

As dificuldades na implementação de um DW evolutivo existem, mas os seus benefícios compensam muito as suas dificuldades pois, ao contrário de um projeto tradicional onde pode ser necessário esperar anos até que todas as bases estejam integradas em um DW central, o projeto evolutivo permite que os usuários tenham acesso a funcionalidades em prazos muito mais curtos, de poucas semanas. O exemplo de aplicação do Capítulo 5 mostrou a viabilidade de um projeto de DW evolutivo e, apesar das poucas iterações apresentadas não terem sido suficientes para que todas as dificuldades mencionadas fossem identificadas, foi mostrado que o projeto atende sua proposta inicial e que sua implementação é viável.

Para os clientes que passaram a utilizar o novo ambiente analítico, houve um impacto bastante positivo. A maior automatização do processo de carga diminuiu o trabalho dos analistas na geração destes relatórios, além de ter reduzido seu tempo de entrega. Além disso, uma maior variedade de relatórios que até então não eram feitos, passaram a ser disponibilizados, permitindo uma maior variedade de análises pelos gestores, passando a contribuir para um melhor entendimento dos dados e aumentando assim a capacidade de acerto do processo de tomada de decisão.

\subsection{Contribuições do trabalho}

Dentre as principais contribuições deste trabalho estão:

- Identificação das duas práticas ágeis principais ao trabalho, e de como aplicar essas práticas no método tradicional de construção de DW para obter os benefícios desejados.

- Descrição e adaptação da técnica de priorização RFV, resultando em uma técnica capaz de selecionar um conjunto mínimo de dados para que um escopo reduzido seja trabalhado na iteração do DW evolutivo.

- Identificação de práticas ágeis complementares que, ou têm alguma necessidade, ou apenas uma 
maior propensão a serem utilizadas devido à aplicação das duas práticas ágeis principais.

- Catalogação das principais evoluções de bancos de dados e classificação das que melhor se adaptam a um DW evolutivo.

- Revisão da literatura e descrição de uma extensão do método de engenharia de Kimball, com maiores capacidades evolutivas que o seu processo original.

\subsection{Pesquisas Futuras}

A aplicação de métodos ágeis em projetos de DW é uma área de estudos pouco explorada com um alto potencial de crescimento. Como áreas de pesquisas futuras, podem ser feitas as seguintes propostas:

1. O trabalho propôs a aplicação de práticas ágeis em um processo de engenharia já existente, estendendo este método. Um passo à frente seria desenvolver um método de engenharia para a construção de um DW evolutivo, com características ágeis em suas diversas etapas.

2. Outra área que pode ser também bastante pesquisada é relativa à técnica de priorização para seleção do conjunto mínimo de dados. Este trabalho utilizou uma técnica RFV, que pode ser substituída por outras mais aplicáveis ou mais eficientes. Também podem ser feitas propostas e estudos comparativos entre diferentes técnicas, melhorando o processo de seleção do conjunto de dados fundamental da iteração.

3. Os métodos de bancos de dados evolutivos foram utilizados no trabalho e, apesar do grande número de refatorações e de transformações existentes para bancos e para sistemas de softwares, não há uma catalogação que as direcione ao ambiente de DW. Pode ser uma proposta de estudo interessante relacionar padrões de evolução de banco no contexto de um DW incluindo, por exemplo, padrões de evolução do processo de ETL.

4. Quando uma versão do modelo dimensional é entregue ao cliente, uma nova iteração de desenvolvimento pode ser iniciada, e diversas versões podem ser desenvolvidas e entregues desta forma. Um assunto que pode ser pesquisado é a definição do momento certo para que as atenções da equipe de desenvolvimento se voltem a outro departamento da empresa, iniciando um novo um modelo dimensional em um novo ciclo iterativo de trabalho. 


\section{Apêndice A}

\section{Apêndice: Alguns exemplos de evoluções de BD}

Este apêndice traz um catálogo das evoluções de banco de dados utilizadas ou referenciadas no trabalho, com explicações, códigos e exemplos para aplicação em banco de dados. A classificação seguirá os padrões do trabalho de Ambler [54], mas com um maior direcionamento a DW.

Ao realizar uma evolução, testes podem ser elaborados para validação. Eles devem ser simples o suficiente para que possam ser executados sempre. O nível de sofisticação dos testes depende muito do desenvolvedor, e eles devem ajudar a garantir a integridade e a qualidade dos dados do DW. Segue agora o catálogo de refatorações e transformações úteis ao projeto, com uma descrição de seus efeitos em outras partes do ambiente analítico.

\section{Adicionar Coluna}

Motivação: A cada iteração evolutiva, novos requisitos podem demandar novas colunas nas tabelas do DW.

Problemas potenciais: Deve-se assegurar que a coluna que será adicionada já não existe em alguma tabela do banco, ou mesmo uma coluna com outro nome, mas com o mesmo significado.

Mecânica de atualização do esquema: O modelo dimensional é o primeiro a ser alterado para refletir a adição de uma nova coluna, seguido pelo modelo físico. As duas alterações devem ser feitas em conformidade com os padrões existentes no projeto, respeitando as nomenclaturas e os demais padrões de desenvolvimento.

ALTER TABLE VENDAS ADD ID_PRODUTO INTEGER NOT NULL;

Alteração do processo de carga: Realizadas as alterações no modelo dimensional e no modelo físico, o processo de carga ETL deve ser adaptado para incluir os campos adicionados. 
Alteração das aplicações de acesso: Além da trilha de dados, a adição de uma coluna também causa alterações na trilha das aplicações de BI.

\section{Remover Coluna}

Motivação: Há algumas situações em que pode ser necessário remover uma coluna do DW, como em uma reestruturação do modelo.

Problemas potenciais: A remoção de uma coluna em uma tabela com muitos dados pode demorar. Por isso, é recomendado remover a coluna durante janelas de baixa utilização. Além disso, pode ser necessário manter os dados da coluna e, neste caso, é preciso fazer uma migração antes de removê-la (por exemplo quando for feita a migração do campo nome_completo para dois campos: nome e sobrenome).

Mecânica da atualização do esquema: O modelo dimensional é o primeiro a ser alterado para refletir a remoção da coluna, seguido pelo modelo físico. Um exemplo de código SQL para remover uma coluna de uma tabela é este abaixo:

ALTER TABLE PRODUTO DROP COLUMN VALOR;

Também podem ser usados comandos que otimizem a remoção da coluna, como por exemplo o comando SET UNUSED, que tem melhor desempenho em relação ao DROP COLUMN, mas apenas oculta a coluna dos usuários, sem removê-la fisicamente. Pode ocorrer também de que o SGBD não ofereça estas opções, e a estratégia deve então ser escolhida de acordo com as características do banco de dados em uso.

\section{Alteração dos programas de acessos:}

Todos os programas que apontem para a coluna devem ser adaptados para funcionarem também após sua remoção, dentro da nova estrutura do banco.

\section{Renomear Coluna}

Motivação: Esta refatoração costuma ser aplicada quando há necessidade de adequação do esquema aos padrões corporativos ou, simplesmente, para aumentar a clareza do nome da coluna.

Problemas potenciais: Deve-se analisar com cuidado os benefícios trazidos por esta alteração em relação ao trabalho para realizá-la, que pode envolver sistemas externos, adaptação em testes e do processos de carga. Também deve ser mantida a consistência do ambiente, ou seja, se um campo de nome VTOT for renomeado para VALOR_TOTAL, então é importante garantir que todas as tabelas com este campo sejam alteradas. 
Mecânica da atualização do esquema: A exemplo das refatorações anteriores, o modelo dimensional é o primeiro a ter a alteração efetuada, seguido pelo modelo físico e pelo processo de ETL.

\section{Alteração dos programas de acessos:}

A sugestão de Ambler [54] é que a alteração no nome da coluna não seja realizado de uma vez, e que passe por um período de transição. O procedimento sugerido segue os três seguintes passos:

(a) Adicionar uma nova coluna com o nome correto

ALTER TABLE VENDAS ADD VALOR_TOTAL INTEGER NOT NULL;

(b) Sincronização entre as colunas, com a adição de uma trigger para que as duas colunas tenham sempre os mesmos valores durante o período de transição, que deve ter um período definido e divulgado aos usuários.

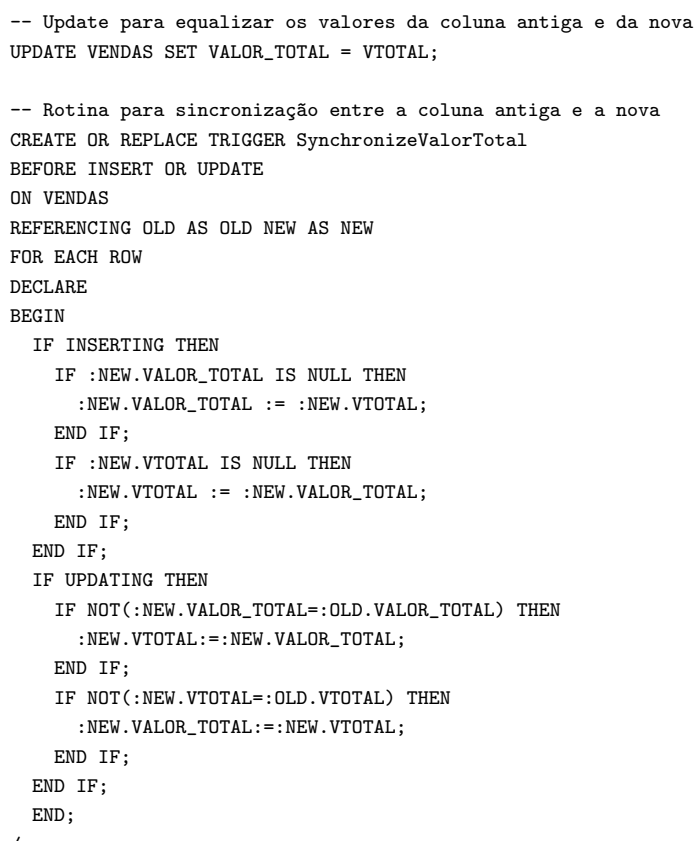

(c) Remover a coluna antiga, após o término da migração, com a garantia dada pela rotina de sincronização de que os dados das duas colunas estão iguais.

ALTER TABLE VENDAS DROP VTOTAL;

A mecânica desta refatoração deve incluir as alterações no processo de ETL e de toda a trilha de BI, para que somente o novo nome da coluna seja utilizado no projeto. 


\section{Adicionar Tabela}

Motivação: Novos requisitos podem exigir a adição de uma nova tabela no banco. Pelo caráter evolutivo do DW, novas tabelas podem ser adicionadas com freqüência, tornando o modelo de dados cada vez mais completo.

Problemas potenciais: É importante verificar se a tabela que será inserida já não existe no banco, ou ainda, se não existe alguma outra tabela que corresponda parcialmente à tabela que será adicionada. Neste caso, pode ser mais simples refatorar a tabela existente para adicionar nela as novas características desejadas.

Mecânica da atualização do esquema: O primeiro passo é novamente a alteração do modelo de dados seguido pelo modelo físico, que devem refletir logicamente e fisicamente a nova tabela do modelo. Um possível comando de criação para a tabela é este a seguir:

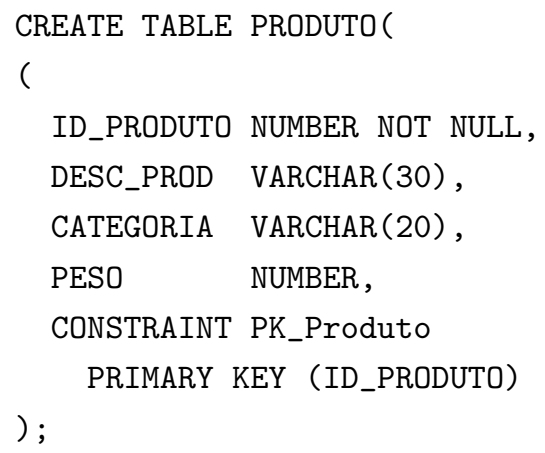

Alteração dos programas de acessos: A adição de uma nova tabela ocorre pois há algum tipo de necessidade do usuário pelos dados desta nova tabela. Assim, espera-se que a trilha dos programas de BI seja estendida com as informações da nova tabela, seja com a adição de campos em relatórios existentes ou pela criação de novos relatórios com a tabela adicionada. O processo de carga também deve ser atualizado.

\section{Remover Tabela}

Motivação: Esta transformação é aplicada quando uma tabela deve ser removida do modelo de dados por não ter mais função na base ou por motivo de reestruturação do ambiente.

Problemas potenciais: Ao remover uma tabela do modelo de dados, pode ser necessário preservar seus dados antes e, neste caso, os dados devem ser migrados para outras tabelas do esquema.

Mecânica da atualização do esquema: A alteração do modelo dimensional e do modelo físico são o primeiro ponto onde ocorre a remoção da tabela. Uma técnica interessante é realizar uma remoção em duas etapas: na primeira, a tabela que será removida tem seu 
nome trocado, para garantir que o sistema continua funcionando sem ela. Na segunda, após algum tempo que a primeira etapa tiver sido executada, a tabela pode ser removida do banco de dados:

-- Passo 1

ALTER TABLE TabCusto RENAME TO TabCustRemovida;

-- Passo 2

DROP TABLE TabCustoRemovida;

O processo ETL deve refletir a remoção da tabela, e todas as referências a ela precisam ser removidas do processo.

Alteração dos programas de acesso: Por fim, o processo da trilha de aplicações de BI deve sofrer as alterações necessárias para que a tabela seja removida. O cuidado a ser tomado neste momento é que podem haver dados nos relatórios de BI que talvez não tenham que ser removidos, mas sim substituídos por outras fontes do DW.

\section{Renomear Tabela}

Motivação: A principal razão para aplicar esta refatoração é de fazer a tabela ter um nome mais claro, ou ainda, para aplicar padrões corporativos não atendidos pela nomenclatura da tabela.

Problemas potenciais: Deve ser feita uma boa análise das vantagens de aplicar esta refatoração, em relação ao esforço que será realizado.

Mecânica da atualização do esquema: Novamente, a alteração do nome da tabela ocorre primeiro no modelo dimensional e no modelo físico. No entanto, Ambler [54] sugere uma alteração em duas etapas, com a utilização de uma tabela intermediária e a criação de um procedimento para sincronização desta tabela com a tabela que deve ser renomeada.

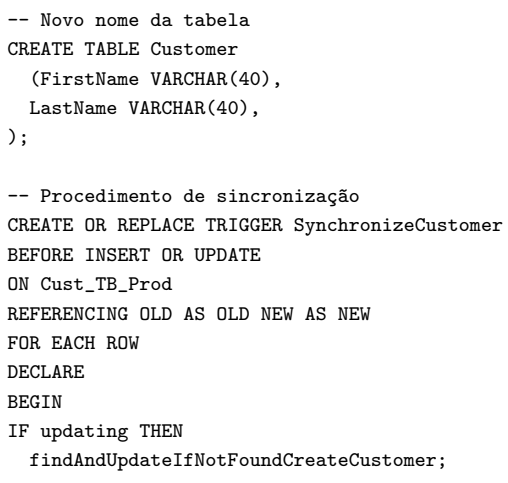




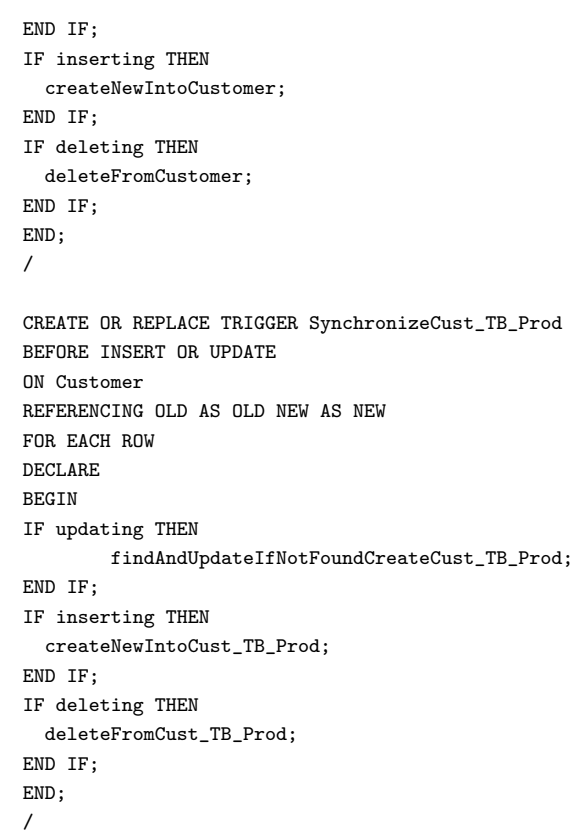

E após todos os desenvolvimentos estarem finalizados, a tabela antiga "Cust_TB_Prod" pode ser removida.

DROP TABLE Cust_TB_Prod;

Uma outra possibilidade para a aplicação desta refatoração seria realizar diretamente a troca do nome da tabela, e criar uma view com o nome antigo para manter todo o restante do processo funcionando normalmente.

-- Passo 1

ALTER TABLE Cust_tb_Prod RENAME TO Customer;

-- Passo 2

CREATE VIEW Cust_tb_Prod AS

SELECT * FROM Customer;

Alteração dos programas de acessos: A trilha de BI deve refletir as alterações aplicadas no item anterior, com a alteração do nome da tabela em todos os possíveis relatórios de BI. 


\section{Referências Bibliográficas}

[1] Chris Adamson and Mike Venerable, Data warehouse design solutions, John Wiley \& Sons, Inc., New York, NY, USA, 1998.

[2] Scott Ambler, The process of database refactoring: Strategies for improving database quality, Acessado em 07/02/2009 em http://www.agiledata.org/essays/databaseRefactoring.html.

[3] _ Agile database techniques effective strategies for the agile software, John Wiley \& Sons, 2003.

[4] Kent Beck, Extreme programming: A gentle introduction, Acessado em 20/08/2008 em http://www.extremeprogramming.org.

[5]_ Sunit projet, Em sunit.sourceforge.net.

[6] _ Extreme programming explained: Embrace change, Addison-Wesley, Reading, Massachusetts, 1999.

[7] Kent Beck and Cynthia Andres, Extreme programming explained: Embrace change, 2a ed., Addison-Wesley, Reading, Massachusetts, 2004.

[8] Kent Beck, Mike Beedle, Arie Van Bennekum, Alistair Cockburn, Ward Cunningham, Martin Fowler, James Grenning, Jim Highsmith, Andrew Hunt, Ron Jeffries, Jon Kern, Brian Marick, Robert C. Martin, Steve Mellor, Ken Schwaber, Jeff Sutherland, and Dave Thomas, Manifesto for agile software development, Em www.agilemanifesto.org.

[9] Kent Beck and Ward Cunningham, A laboratory to teach object-oriented thinking, OOPSLA (1989), 1-6.

[10] Mike Biere, Business intelligence for the enterprise, Prentice Hall PTR, Junho 2003.

[11] B. Boehm, A spiral model for software development and enhancement, Computer 21 (1988), no. $5,61-72$.

[12] F. Brooks, The mythical man-month, Addison-Wesley, 1975.

[13] Luís Cavique, Micro-segmentação de clientes com base em dados de consumo: Modelo rm-similis, Revista Portuguesa e Brasileira de Gestão Vol 2 (2003), no. 3, 72-77.

[14] Alistair Cockburn, Agile software development, Addison Wesley, 2002.

[15] _ _ A human-powered methodology for small teams, Addison-Wesley Professional, 2004. 
[16] Alexandre Freire da Silva, Reflexões sobre o ensino de metodologias ágeis na academia, na indústria e no governo, Master's thesis, USP, June 2007, Orientador: Prof. Dr. Fábio Kon.

[17] Bernard de Longevialle and Thierry Grunspan, Bnp paribas - ratingsdirect, Standard \& Poors (2008).

[18] Ronald G. Drozdenko and Perry D. Drake, Optimal database marketing: Strategy, development, and data mining, 1a ed., Sage Publications, Inc, Março 2002.

[19] Wayne W. Eckerson, Performance dashboards: Measuring, monitoring, and managing your business, Wiley, Outubo 2005.

[20] Martin Fowler, Refactoring: Improving the design of existing code, Addison-Wesley, 1999.

[21] Gartner, More than 50 percent of data warehouse projects will have limited acceptance or will be failures through 200\%, http://www.gartner.com, 2005.

[22] Michael Haisten, The next stage in data warehouse evolution, parts 1,2 and 3, DM Review (1999), http://www.dmreview.com/news/946-1.html, http://www.dmreview.com/news/13121.html, http://www.dmreview.com/news/1410-1.html.

[23] Jim Highsmith, Agile software development ecosystems, Addison Wesley, 2002.

[24] Arthur Middleton Hughes, Strategic database marketing, 3a ed., McGraw-Hill, Agosto 2005.

[25] IEEE Standard 610.12-1990, Iee standards collection: Software engineering, 1993.

[26] W. H. Inmon, Building the data warehouse, QED Information Sciences, Inc., Wellesley, MA, USA, 1991.

[27] _ Building the data warehouse, Wiley Publishing, Inc, 2000.

[28] Isabel Cristina Italiano, Um modelo para manutenção de esquema de dados em Data Warehouses implementados em plataformas móveis, Ph.D. thesis, Universidade de São Paulo, Junho 2007, Orientador Prof. Dr. Jorge Rady de Almeida Junior.

[29] Isabel Cristina Italiano and João Eduardo Ferreira, $O$ uso de visões materializadas em data warehouses, MAC 5701 (2000).

[30] J Johnson, Keynote speech xp, Standish Group, Sardinia, Italy, 2002.

[31] Robert S. Kaplan and David P. Norton, The balanced scorecard: Translating strategy into action, 1a ed., Harvard Business School Press, 1996.

[32] _ Strategy maps: Converting intangible assets into tangible outcomes, 1a ed., Harvard Business School Press, Fevereiro 2004.

[33] _ Execution premium, 1a ed., Harvard Business School Press, Julho 2008.

[34] Morgan Kaufmann, Data quality: The accuracy dimension (the morgan kaufmann series in data management systems), 2002.

[35] Ralph Kimball, The data warehouse toolkit: Practical techniques for building dimensional data warehouses, John Wiley, 1996. 
[36] _ The data warehouse toolkit: Practical techniques for building dimensional data warehouses, 2a ed., John Wiley, 2002.

[37] Ralph Kimball, Laura Reeves, Warren Thornthwaite, Margy Ross, and Warren Thornwaite, The data warehouse lifecycle toolkit: Expert methods for designing, developing and deploying data warehouses with cd rom, John Wiley \& Sons, Inc., New York, NY, USA, 1998.

[38] Ralph Kimball, Laura Reeves, Warren Thornthwaite, Margy Ross, Warren Thornwaite, and Bob Becker, The data warehouse lifecycle toolkit, 2a ed., John Wiley \& Sons, Inc., New York, NY, USA, 2008.

[39] Craig Larman, Agile and iterative development: A manager's guide, Addison-Wesley, 2003.

[40] Luiz Henrique Lorentz, Coleta de requisitos - uma abordagem visando data warehouse, Master's thesis, Universidade Federal do Rio Grande do Sul, Novembro 2003, Orientadora Prof. Dr. Mara Abel.

[41] Bradac M., Perry D., and Votta L., Prototyping a process monitoring experiment, IEEE Trans. Software Engineering, 1994.

[42] P. Naur and B. Randall, Software engineering: A report on a conference sponsored by the nato science committee, NATO, 1969.

[43] Willian F. Opdyke, Refactoring object-oriented frameworks, Ph.D. thesis, University of Illinois, 1992.

[44] Leon J. Osterweil, Philippe Kruchten, Martin Fowler, and Wilhelm Schäfer, Lightweight vs. heavyweight processes: is this even the right question?, ICSE '02: Proceedings of the 24th International Conference on Software Engineering (New York, NY, USA), ACM, 2002, pp. 649-649.

[45] R. S. Pressman, Software engineering, 6a ed., McGraw-Hill, 2006.

[46] Moody's Credit Research, Moody's affirms bnp paribas' ratings with stable outlook, Global Credit Research - Rating Action (2008).

[47] Danilo Toshiaki Sato, Uso eficaz de métricas em métodos ágeis de desenvolvimento de software, Master's thesis, Universidade de São Paulo, Agosto 2007, Orientador Prof. Dr. Alfredo Goldman Vel Lejbman.

[48] Ken Schwaber, Agile project management with scrum, Microsoft Press, 2004, 11,24,32,120.

[49] Ken Schwaber and Mike Beedle, Agile software development with scrum, Prentice Hall, 2001, $11,24,32,61,120$.

[50] Ian Sommerville, Engenharia de software, 6a ed., Addison Wesley, 2003.

[51] Norman E. Sondak, Integrating pc's into the information center (session overview), CSC '85: Proceedings of the 1985 ACM thirteenth annual conference on Computer Science (New York, NY, USA), ACM, 1985, p. 209.

[52] R. Tanler, The intranet data warehouse, 1997.

[53] CIM Insights Team and Paul Fifield, Segmentação pelo contexto, HSM Management (2005). 
[54] Ambler S. W. and Sadalage P. J., Refactoring databases, Addison Wesley, 2006. 